Material characterisation by means of
alternative scanning turnnelling spectroscopy tools

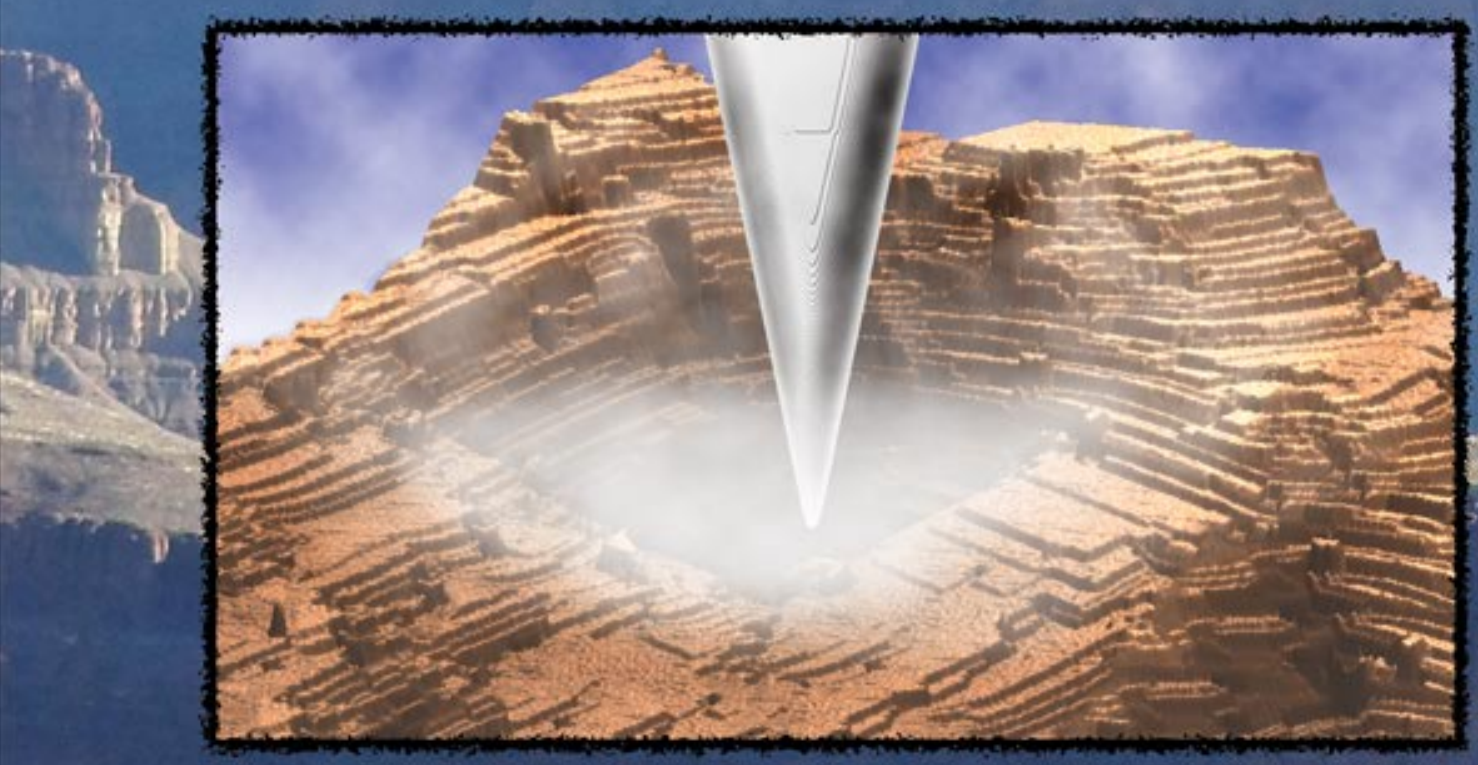

3). 
Material characterisation by means of alternative scanning tunnelling spectroscopy tools 


\section{Composition of graduation committee:}

Chairman and secretary:

Supervisor:

Co-supervisor:

Members:

Referee:
Prof. dr. ir. Hans Hilgenkamp

Prof. dr. ir. Harold J. W. Zandvliet

Dr. E. Stefan Kooij

Prof. dr. ir. J.E. (André) ten Elshof

Prof. dr. J.G.E. (Han) Gardeniers

Dr. ir. Sense Jan van der Molen

Prof. dr. ir. Bene Poelsema

Prof. dr. Wulf Wulfhekel

Dr. Meike A. Stöhr

The work described in this thesis was carried out in the Physics of Interfaces and Nanomaterials group, MESA + Institute for Nanotechnology, University of Twente, the Netherlands.

This research has been supported by the Dutch Technology Foundation STW, which is part of the Netherlands Organisation for Scientific Research (NWO) and partly funded by the Ministry of Economic Affairs within the framework of the 'NEEDLChem' project (project number 11411).

Published by Physics of Interfaces and Nanomaterials, University of Twente. Cover Design: Inset - "Probing the unknown", based on a 3D image of $\mathrm{Cu}(100)$ in $\mathrm{HCl}$ solution. Background - Indian Garden/Plateau Point, Grand Canyon, Arizona. Printed by: Gildeprint - Enschede.

(C). Hellenthal, 2015, Enschede, the Netherlands

No part of this publication may be stored in a retrieval system, transmitted or reproduced in any way, including but not limited to photocopy, photograph, magnetic or other record, without prior agreement and written permission of the publisher.

ISBN: 978-90-365-3866-4

DOI: $10.3990 / 1.9789036538664$ 


\title{
MATERIAL CHARACTERISATION BY MEANS OF ALTERNATIVE SCANNING TUNNELLING SPECTROSCOPY TOOLS
}

\author{
PROEFSCHRIFT
}

\author{
ter verkrijging van \\ de graad van doctor aan de Universiteit Twente, \\ op gezag van de rector magnificus, \\ Prof. Dr. H. Brinksma, \\ volgens besluit van het College voor Promoties \\ in het openbaar te verdedigen \\ op vrijdag 29 mei 2015 om 14:45 uur
}

door

Chris Hellenthal

geboren op 3 december 1987

te Ermelo 
Dit proefschrift is goedgekeurd door de promotor:

Prof. dr. ir. H.J.W. Zandvliet

en de co-promotor:

Dr. E.S. Kooij 


\section{Contents}

1 Introduction 1

1.1 Quantum Mechanical Tunnelling .............. 2

1.2 Scanning Tunnelling Microscopy . . . . . . . . . . . . . . 4

1.3 Scanning Tunnelling Spectroscopy . . . . . . . . . . . 7

$1.3 .1 \quad$ Open-loop STS . . . . . . . . . . . . . . 8

1.3 .2 Closed-loop . . . . . . . . . . . . . . . . . . 10

1.3 .3 Lock-in STS . . . . . . . . . . . . . . . . . . . . . . . . . . . . . . . . .

1.4 Motivation . . . . . . . . . . . . . . . . . . 14

1.5 Scope and Outline . . . . . . . . . . . . . . . 14

2 Experimental setup and ECSTM theory 21

2.1 RHK UHV Variable Temperature STM . . . . . . . . . . 22

2.2 RHK Rev9 ECSTM Setup . . . . . . . . . . . . . . . 24

2.2 .1 Electrochemical Periphery . . . . . . . . . . . 26

2.3 Electrochemistry Basics . . . . . . . . . . . . . . 28

2.3.1 Solid-liquid interface in electrochemistry . . . . . . . 29

2.3.2 Electrochemical Methods . . . . . . . . . . . 30

2.4 Introduction to Electrochemical STM . . . . . . . . . . 33

2.4.1 Tunnelling in aqueous environments . . . . . . . . 33

2.4.2 ECSTM Operational Principle . . . . . . . . . . . 34

3 Determining the LDOS in the constant current STM mode 37

3.1 Introduction . . . . . . . . . . . . . . . 38

3.2 Model . . . . . . . . . . . . . . . . . . . . . . . . . . . 39

3.2.1 Direct calculation . . . . . . . . . . . . . . 39

3.2 .2 LDOS fitting method . . . . . . . . . . . 43

3.3 Simulations . . . . . . . . . . . . . . . . 45

3.4 Conclusions . . . . . . . . . . . . . . . . . . . 49 
4 Transition voltage spectroscopy of STM vacuum junctions 51

4.1 Introduction . . . . . . . . . . . . . . 52

4.2 Experimental . . . . . . . . . . . . . . . . 54

4.3 Results and Discussion . . . . . . . . . . . . . . . 54

4.4 Conclusions . . . . . . . . . . . . . . . . . 60

5 Determining the tunnelling barrier in open- and closed-loop STM 65

5.1 Introduction . . . . . . . . . . . . . 66

5.2 Model ........................ 67

5.2.1 Current-distance spectroscopy . . . . . . . . . . . 69

5.2 .2 Constant-current spectroscopy . . . . . . . . . . 71

5.3 Experimental . . . . . . . . . . . . . . . . . 73

5.4 Results and Discussion . . . . . . . . . . . . . . . 73

5.5 Conclusions . . . . . . . . . . . . . . . . . . 79

6 Investigating the tunnelling gap in non-vacuum conditions $\quad 83$

6.1 Introduction . . . . . . . . . . . . . . . . 84

6.2 Experimental . . . . . . . . . . . . . . . . . . 85

6.3 Model . . . . . . . . . . . . . . . . . . . . 86

6.4 Results and Discussion . . . . . . . . . . . . . . . 88

6.5 Conclusions . . . . . . . . . . . . . . . . 92

$\begin{array}{ll}\text { Summary } & 95\end{array}$

$\begin{array}{ll}\text { Samenvatting } & 99\end{array}$

$\begin{array}{ll}\text { List of publications } & 103\end{array}$

$\begin{array}{ll}\text { Naschrift en dankwoord } & 105\end{array}$ 


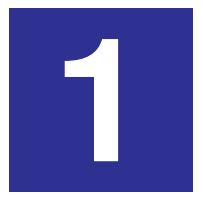

\section{Introduction}

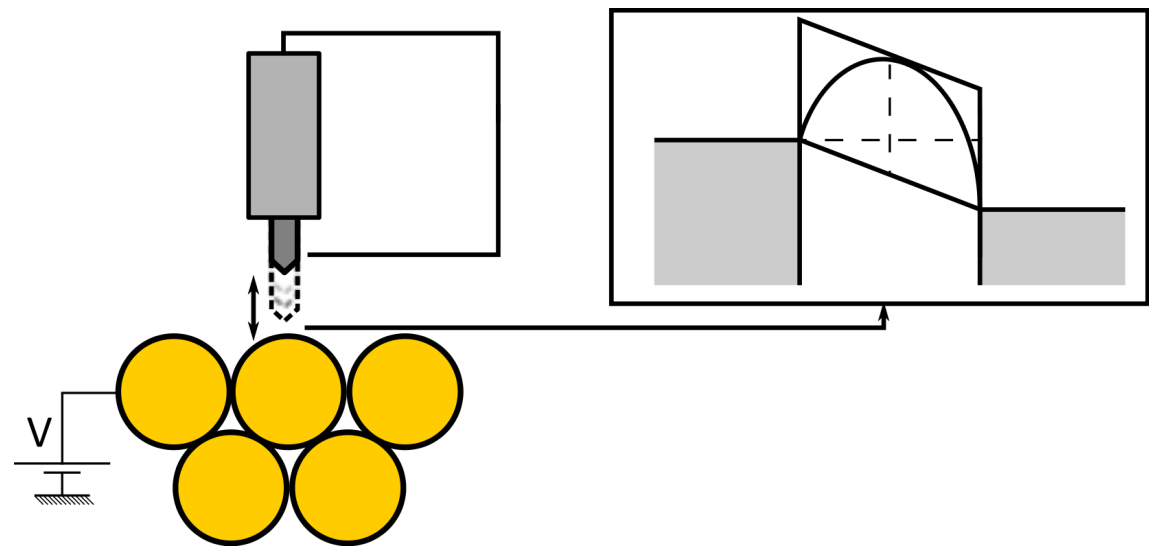

This chapter includes a brief historical and theoretical overview of the scanning tunnelling microscopy methods that have been used in the realisation of this thesis. The introduction of the scanning tunnelling microscope and the underlying quantum mechanical principles serves as an entrance point to the more complex work described in the later chapters. 

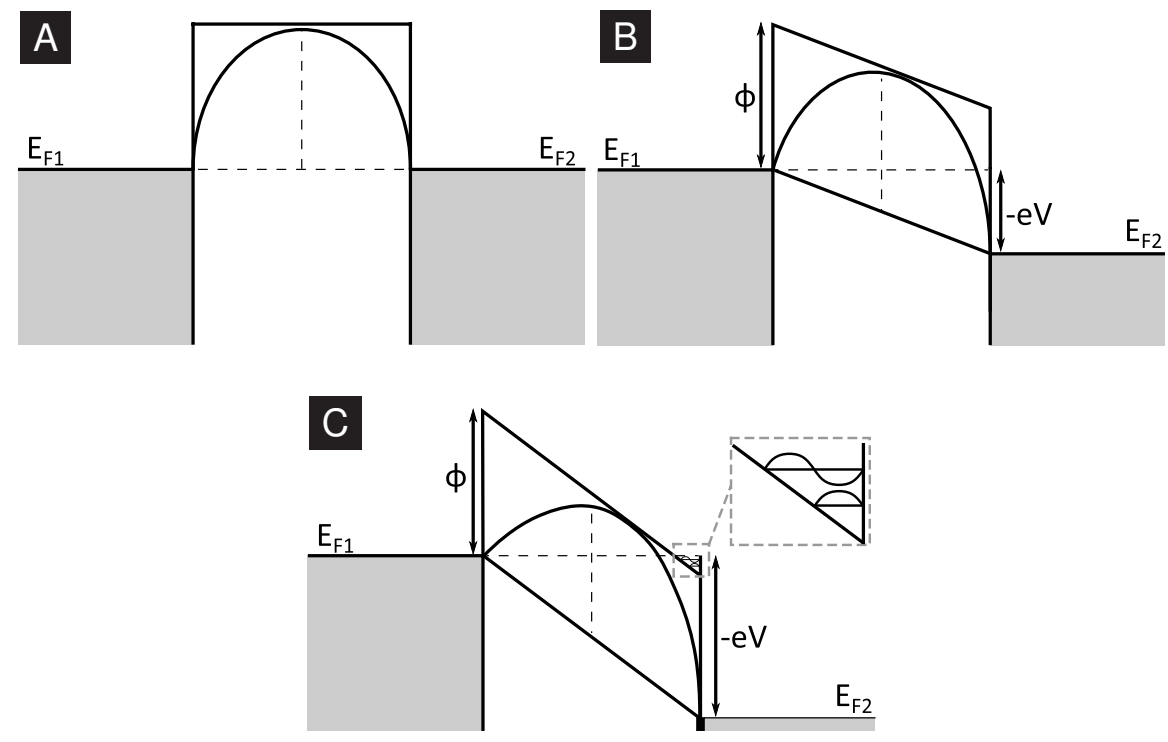

Figure 1.1: Schematic representation of different tunnelling regimes. The inset in Figure $\mathrm{C}$ shows the standing wave patterns known as Gundlach oscillations.

\subsection{Quantum Mechanical Tunnelling}

The concept of quantum mechanical tunnelling ${ }^{1,2}$ lies at the heart of a variety of natural phenomena, such as nuclear fusion, fission and decay ${ }^{3}$ and charge transfer in biological systems. ${ }^{4}$ A selection of man-made (potential) applications of the tunnelling process includes digital data storage, ${ }^{5}$ energyefficient tunnel field-effect transistors (TFET), ${ }^{6,7}$ the aptly named tunnel $\operatorname{diode}^{8,9}$ and scanning tunnelling microscopy (STM). ${ }^{10-12}$ Tunnelling also illustrates some of the striking dissimilarities between the realms of classical and quantum mechanics.

When two electrodes are placed in very close proximity to one another, electrons may be transported from one electrode to the other via quantum mechanical tunnelling. Tunnelling takes place when the wave functions of both electrodes overlap. Classically speaking, to remove an electron from one electrode and transfer it to the other, one would need an energy $\frac{\phi_{1}+\phi_{2}}{2}+$ $e \Delta V$. Here $\phi_{n}$ is the work function of the electrode which indicates the 
amount of energy required to extract an electron from (or inject it into) the electrode, $e$ is the elementary charge constant and $\Delta V$ is the vacuum potential barrier between the two electrodes. However, electrons with an energy appreciably lower than $\frac{\phi_{1}+\phi_{2}}{2}+e \Delta V$ may also cross the potential barrier between the electrodes; a direct result of the wave-particle duality of elementary particles. ${ }^{13}$

The tunnel current, i.e. the amount of electrons that flow between the electrodes, depends on their Fermi levels. Without an applied bias voltage between the electrodes, their Fermi levels will be balanced, i.e. filled electron states in one electrode match filled electron state in the other, leading to a square potential barrier as shown in Figure 1.1A. In this case, the amount of electrons tunnelling from one electrode to the other will be equal to the amount of electrons tunnelling in the opposite direction, and no net current will flow. By applying a positive bias voltage $V$ to electrode 2, its Fermi level is shifted by $-e V$. This leads to the tunnelling barrier becoming triangular in shape (Figure 1.1B), which in turn causes electrons from the filled states of electrode $\mathbf{1}$ to flow into the empty states of electrode 2. Applying a negative bias voltage $-V$ to electrode $\mathbf{2}$ will shift its Fermi level by $e V$, causing electrons from the filled states of electrode $\mathbf{2}$ to flow into electrode 1. Raising the applied bias voltage above the work function $\phi$ leads to the tunnelling barrier becoming trapezoidal in shape, as can be seen in Figure 1.1C. In this scenario, tunnelled electrons have excess energy after passing through the tunnelling barrier, making them unable to directly 'settle into' the vacant states. This gives rise to so-called Gundlach oscillations ${ }^{14}$ as the electrons bounce back and forth within the potential well consisting of the tunnelling barrier and the vacant states in order to decrease their energy.

The mathematical model underlying the concept of quantum mechanical tunnelling has been extensively described by Simmons in $1963,{ }^{15}$ based on earlier work by Sommerfeld and Bethe,${ }^{1}$ as well as Holm. ${ }^{16}$ The tunnelling current $I$ varies linearly with the applied bias voltage and the local density of states (LDOS) of the two electrodes. The tunnelling current varies exponentially with both the tunnelling distance and the work functions of both electrodes. Finally, there is also an inverse dependence between the tunnelling current and the tip-sample separation. However, this term is occasionally omitted due to its limited effect when compared to that of the previously mentioned exponential dependence. Putting all these dependencies together 
yields the following formula:

$$
I \propto \frac{V \rho}{z} e^{-\alpha \sqrt{\phi_{\mathrm{eff}}} z}
$$

where $\rho$ is the LDOS, $\alpha$ is a constant, $\phi_{\text {eff }}=\frac{\phi_{\text {tip }}+\phi_{\text {sample }}}{2}$ is the effective work function and $z$ is the distance between the two electrodes.

\subsection{Scanning Tunnelling Microscopy}

Introduced in the early $1980 \mathrm{~s},{ }^{10,11}$ the invention of the Scanning Tunnelling Microscope (STM) provided surface scientists with a new powerful technique to study a wide variety of conducting samples. Relying on quantum mechanical tunnelling (see preceding section) to generate its measurement signals, a properly configured and operated STM can spatially resolve a probed sample down to the atomic scale while measuring current variations in the order of picoamperes $\left(10^{-12}\right.$ amperes). In addition to imaging, the STM technique has also been used for the manipulation of atoms into ordered structures such as corrals ${ }^{17}$ and letters. ${ }^{18}$ Perhaps most strikingly, a sixty second stop-motion movie consisting of STM images of manipulated atoms currently holds the world record for 'the World's Smallest Stop-Motion Film'. ${ }^{19}$

When performing STM measurements, a tip is brought into close proximity (sub nanometre range) to a conducting sample through the use of piezoelectric actuators whose dimensions can be altered by applying an electric potential to them. The STM tip consists of a conducting material that is resistant to oxidation, such as platinum-iridium or tungsten, and is ideally sharpened to a one-atom apex. A potential difference or bias voltage is applied between the tip and the sample in order to generate a tunnelling current. The exact magnitude of the tunnelling current depends on a great number of factors, but a good approximation is given by a simplified version of Equation 1.1:

$$
I \propto C \rho V e^{-\kappa z} .
$$

Here $I$ is the tunnelling current, $C$ is a constant, $\rho$ is the density of states, $V$ is the applied bias voltage, $\kappa$ is the inverse decay length and $z$ is the tipsample separation distance. Critical to the functionality of the STM during topography measurements is the electronic feedback loop, which ensures that 

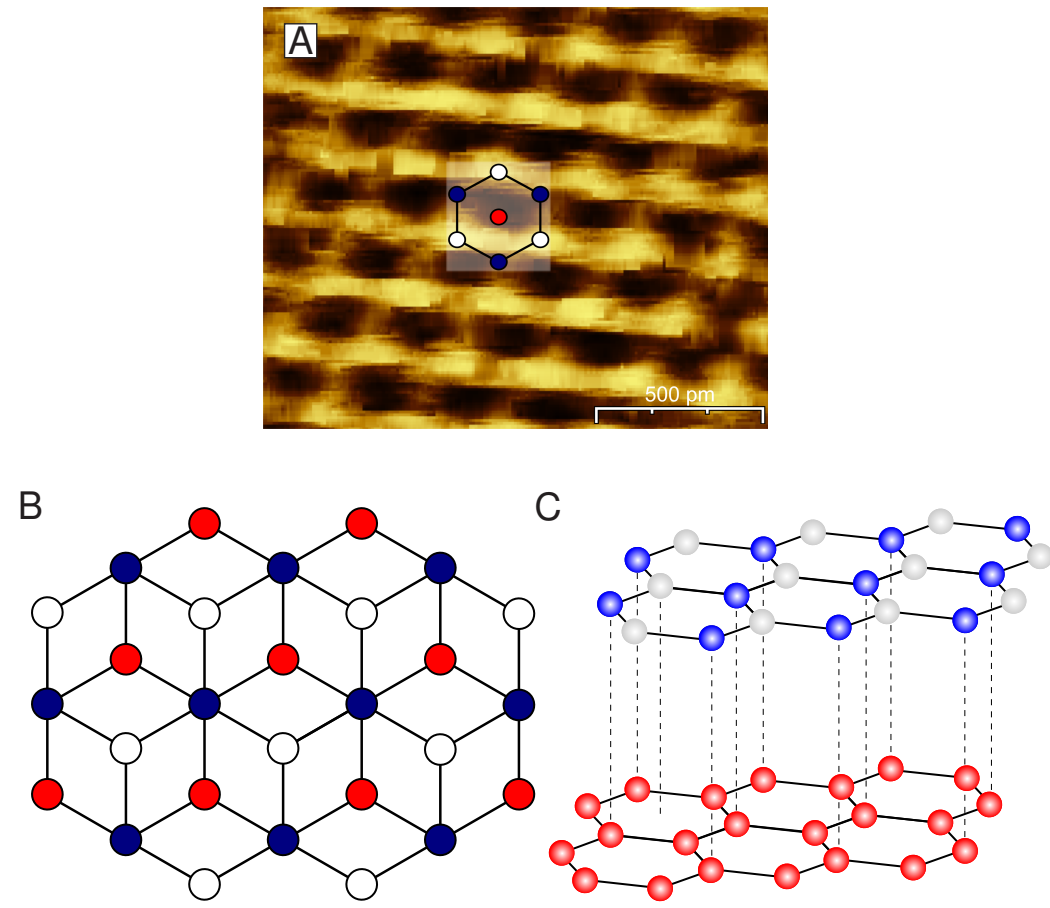

Figure 1.2: A) Topography image of the HOPG surface. The blue circles indicate surface atoms paired with atoms in the underlying layer. B) Schematic top view of the HOPG surface. C) Side view of two graphene layers in the HOPG structure.

the tunnelling current is kept constant at the level desired by the operator of the STM. During operation, an error signal is continuously updated by determining the difference between the measured and desired current, i.e.

$$
\epsilon=I_{0}-I \text {. }
$$

Any changes in the tunnelling current caused by a variation of the parameters in Equation 1.2 will be automatically negated by the STM by retracting the tip from, or extending it towards, the sample depending on the sign and magnitude of the error signal. In most cases, a change in current will be caused by a height variation on the sample, but the STM is also sensitive to the electronic properties of the probed sample which are contained within the local density of states (LDOS). This effect is especially visible when imaging 

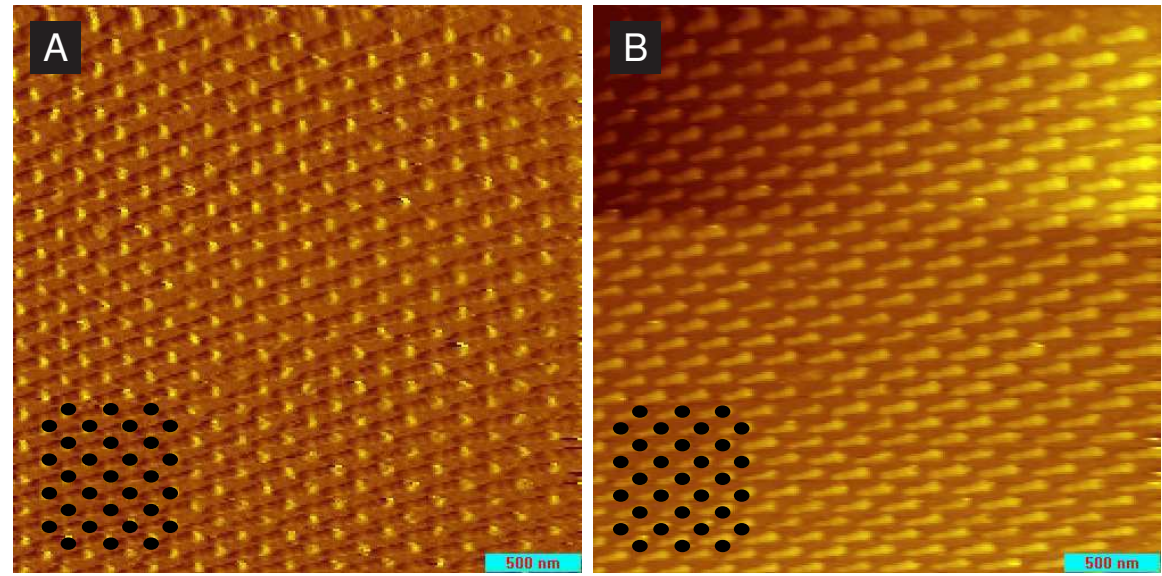

Figure 1.3: STM measurements of a calibration grid, with the grid schematic superimposed in the bottom left corners. A) Current image obtained on calibration grid. B) Topography image obtained on calibration grid. The field of view is $3 \times 3 \mu \mathrm{m}^{2}$.

highly ordered pyrolytic graphite (HOPG), which consists of single layers of graphene stacked in an alternating fashion known as the Bernal structure, ${ }^{20}$ as shown in Figure 1.2. Despite the flat, hexagonal lattice of HOPG, Figure $1.2 \mathrm{~A}$ shows a triangular periodicity due to the electronic interference of atoms in the lower layers of the sample.

While the theory described above deals with an ideal situation, there are many factors present in actual experiments that can cause a distortion in data obtained from scanning a surface. Figure 1.3 shows a schematic representation of a calibration sample consisting of a regularly spaced grid of dots on a platinum-coated silicon surface, superimposed on two different types of measurement. Figure 1.3A and 1.3B respectively show the current image and the topography image obtained from a scan over the calibration grid. The bright spots in both images correspond to the dots present on the surface, whose elevation causes an increase in tunnelling current. Rather than being fully circular, the imaged dots have an elongated shape which is especially visible in Figure 1.3B. This is caused by an effect known as 'tip imaging', which can occur when the STM tip is blunt or consists of multiple smaller tips in close proximity. Due to the fact that tunnelling will always take place via the shortest route between the tip and the sample, the obtained image 
will be a combination of the actual topography of the sample with the shape of the tip 'imprinted' onto it.

The top quarter of Figure 1.3B shows a markedly different contrast from the rest of the image. This is due to the sample lying at an incline with respect to the scanning direction of the tip. To maintain a constant current, the feedback loop will constantly alter the height of the tip, which results in a gradient in the topography image. Most STM controllers allow the user to compensate for this effect by scanning the tip over the surface at a set incline matched to the incline of the sample, as has been done for the rest of the image.

Because of the sensitive nature of the performed measurements, it is of vital importance to reduce noise from outside sources. ${ }^{21}$ Mechanical vibrations from airflow, machines or ambient movement can cause the tip-sample distance to change, leading to distorted images. Sufficiently large vibrations or mechanical shocks can even cause a tip crash, often necessitating the preparation and installation of a new tip in the STM system. Minute changes in temperature can cause the different mechanical parts of the setup to contract or expand leading to drift. This in turn leads to elongated or compressed images, and makes it difficult to resolve smaller structures on the sample. Finally, electronic coupling between the STM controller and the power grid or other devices can lead to (often periodic) noise being superimposed on the bias voltage or the piezo-electric elements of the scanner. Both will lead to a loss of resolution. Fortunately, countermeasures can be deployed to minimise the impact of the different types of noise described above. The specific countermeasures employed during the work described in this thesis will be introduced in the following Chapter.

\subsection{Scanning Tunnelling Spectroscopy}

In addition to recording topography images by scanning the tip over a surface, the STM can also be used to probe the chemical and electronic properties of a sample through the use of scanning tunnelling spectroscopy (STS). ${ }^{22-25}$ When performing STS measurements, the tip is held at a fixed position above the sample to eliminate the effect of topography changes on the tunnelling current. Spectroscopic measurements are often indicated in an $\mathrm{X}(\mathrm{Y})$ format, indicating that the variable $X$ is being measured as a function of $Y$, with all other parameters remaining constant. A large number of different types 
of STS measurements exist, but they can roughly be divided into three categories: open-loop STS, closed-loop STS and lock-in STS.

\subsubsection{Open-loop STS}

During open-loop STS measurements, the feedback loop is disabled (i.e. opened), causing the tip to remain stationary in all three dimensions. Disabling the feedback loop introduces a risk of crashing the tip due to drift, which makes stability an important criterion when performing open-loop measurements. With the feedback loop disabled, the tunnelling current can change, which is used in many open-loop techniques.

Current-voltage or $\mathrm{I}(\mathrm{V})$ spectroscopy is one of the most commonly used modes of spectroscopy and can be used to characterise the probed surface on the electronic level. Equation 1.2 shows a linear dependence of the tunnelling current on the applied bias voltage. However, the density of states is also a function of bias voltage, which means that $\mathrm{I}(\mathrm{V})$ spectroscopy can reveal the basic nature of the sample being probed, as well as the presence of surface states. Rather than using the I(V) characteristics directly, a commonly used technique to determine the density of states of a sample is to calculate the derivative of the tunnelling current with respect to the sample bias, i.e. $\frac{d I}{d V}$.

A simple example is shown in Figure 1.4, which contains simulated I(V) characteristics for four types of materials: an insulator, a semi-conductor, a metal and a metal with surface states. Insulators and semi-conductors both possess a band gap, which means that there are no accessible states within a certain bias voltage range. This leads to a flat plateau around $V=0$ in the $\mathrm{I}(\mathrm{V})$ curve for these materials and a derivative that is equal to zero. The only real distinction between insulators and semiconductors is the width of the band gap; to bridge the band gap of an insulator requires bias voltages in excess of what is normally desirable in an STM system. Metals do not possess a band gap, leading to an $\mathrm{I}(\mathrm{V})$ characteristic that is linear in the case of an ideal, featureless metal. Figure 1.4D shows the influence of surface states on the $\mathrm{I}(\mathrm{V})$ characteristic of a metal. While the $\mathrm{I}(\mathrm{V})$ curve itself is only slightly distorted, the partial derivative $\frac{d I}{d V}$ shows a number of distinct peaks along the spectrum. The I(V) curves presented here are based on an idealised model; using the partial derivative $\frac{d I}{d V}$ to determine the LDOS from experimental measurements can lead to significant inaccuracies. Chapter 3 gives an in-depth overview of the caveats that should be observed when determining the LDOS from spectroscopic measurements. 

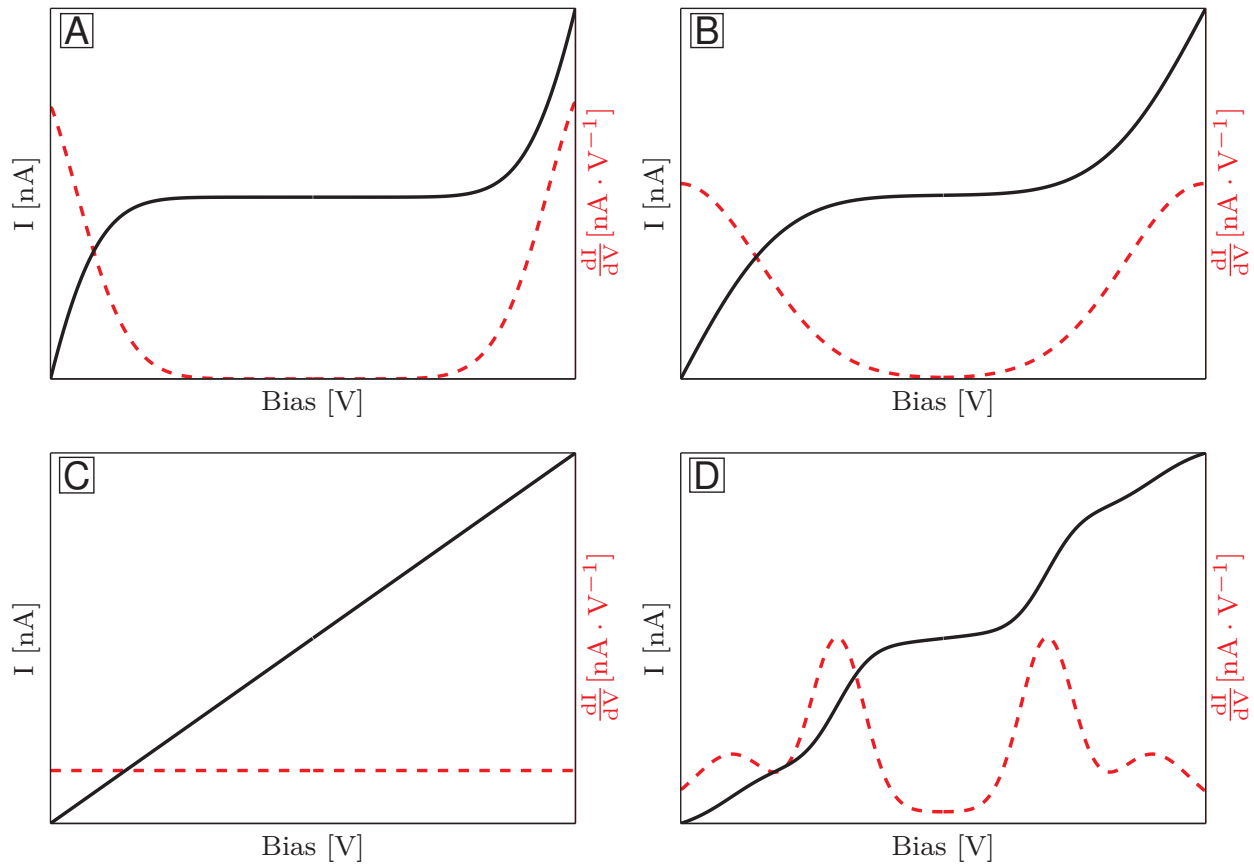

Figure 1.4: Theoretical $\mathrm{I}(\mathrm{V})$ curves (black, solid) and their derivatives (red, dashed) of four types of materials. A) An insulator. B) A semiconductor. C) A metal. D) A metal with surfaces states.

Current-distance or $\mathrm{I}(\mathrm{z})$ spectroscopy is also performed in open-loop and can be used to determine the height of the local tunnelling barrier $\phi$. It follows from Equation 1.2 that measuring the tunnelling current as a function of tipsample separation will yield an exponential curve (Figure 1.5A). The slope of this curve depends on $\kappa$, which is directly related to the local tunnelling barrier height via the expression $\kappa=\alpha \sqrt{\phi}$, where $\alpha$ is a constant. The data from $\mathrm{I}(\mathrm{z})$ measurements are often plotted in the form of logarithmic conductance plots, with the conductance being defined as $G=\frac{I}{V}$. Plotting $\ln (G)$ vs $z$ yields a straight line with slope $-\kappa$ from which the value of $\phi$ can be extracted (Figure 1.5B). When dealing with actual experiments, the value of $\phi$ depends on a number of parameters, making analysis of $\mathrm{I}(\mathrm{z})$ measurements far more involved than the simplistic picture that is given here. Chapter 5 gives a more complete overview of the challenges associated with the analysis of measured $\mathrm{I}(\mathrm{z})$ data. 

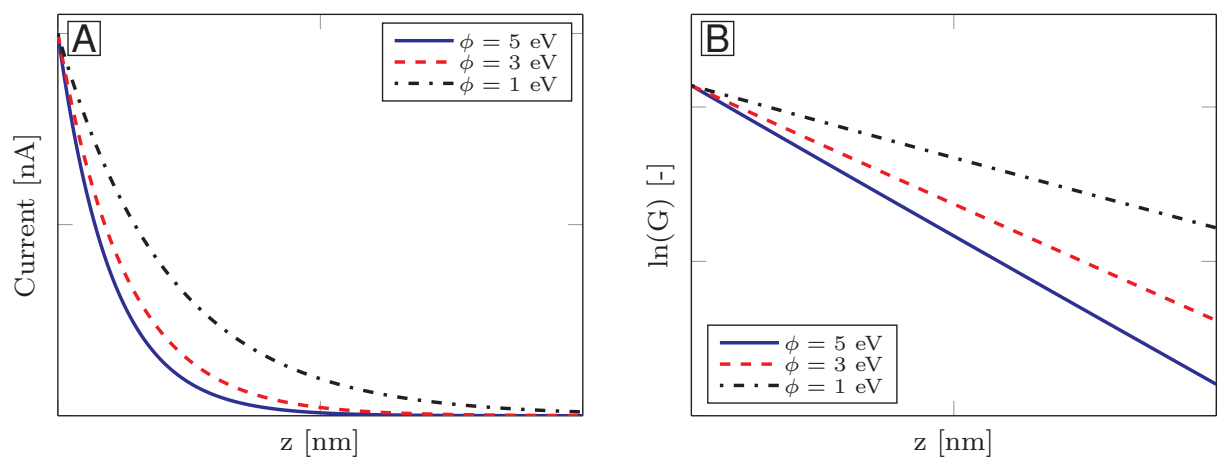

Figure 1.5: A) Simulated I(z) curves for different barrier values. B) The logarithmic conductance plots corresponding to these $\mathrm{I}(\mathrm{z})$ curves.

Current-time or I(t) spectroscopy is not used to determine any specific parameter of the probed system, but rather to study its dynamic behaviour. By simply holding the tip stationary above a feature of interest in the lateral plane and opening the feedback loop, one can determine whether the feature undergoes changes within a limited time frame. ${ }^{26}$ Distance-time or $\mathrm{z}(\mathrm{t})$ spectroscopy is functionally identical, with the only difference being the state of the feedback loop (i.e. open or closed). ${ }^{27,28}$ It should be noted that the state of the feedback loop determines the limit of the temporal resolution during the experiment. During I(t) spectroscopy, the temporal resolution is limited only by the frequency bandwidth of the STM IV-converter, which is typically a few hundred $\mathrm{kHz}$. In contrast, the temporal resolution of a $\mathrm{z}(\mathrm{t})$ experiment also depends on the bandwidth of the feedback loop, which will typically be lower than that of the IV-converter (a few $\mathrm{kHz}$ ).

\subsubsection{Closed-loop}

Closed-loop STS measurements are performed while the feedback loop is active. As such, the tunnelling current stays constant during the measurement, which means that another variable will have to be logged in order to analyse the behaviour of the sample. The obvious variable to use is the tip-sample distance $z$, as follows from Equation 1.2. Most closed-loop methods are alternatives to their open-loop equivalents, with their own advantages and disadvantages. The main advantage of keeping the tunnelling current constant during measurements is the decreased risk of tip deformation due to changes 

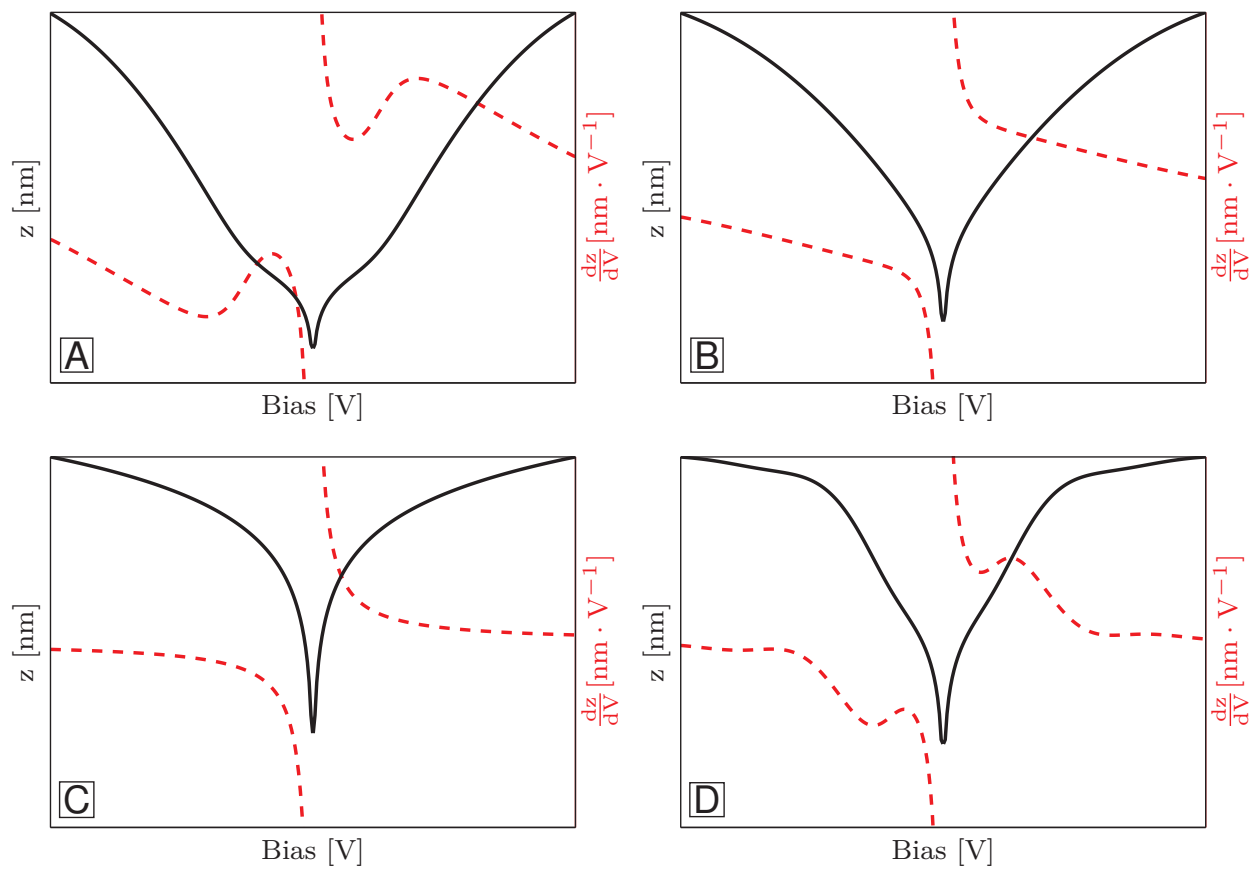

Figure 1.6: Theoretical z(V) curves (black, solid) and their derivatives (red, dashed) of four types of materials. A) An insulator. B) A semiconductor. C) A metal. D) A metal with surfaces states.

in the electric field between the tip and the sample. Another obvious advantage inherent to all closed-loop methods is the fact that they can be performed with all types of STM, even those that do not have a sample-and-hold system necessary to disable the feedback loop. The main disadvantage to keeping the feedback loop active is that any results will be convoluted with the response of the feedback loop, e.g. a slow feedback response will lead to non-constant current and a reduced response in the tip-sample distance signal.

Distance-voltage or $z(V)$ spectroscopy is the analogue to $\mathrm{I}(\mathrm{V})$ and $\mathrm{I}(\mathrm{z})$ spectroscopy and can be used to determine the density of states of a sample as well as the local tunnelling barrier. Figure 1.6 can be used to illustrate the advantages and disadvantages of $\mathrm{z}(\mathrm{V})$ spectroscopy with regards to the more conventional $\mathrm{I}(\mathrm{V})$ method. One the most obvious limitations of $\mathrm{z}(\mathrm{V})$ spectroscopy is the behaviour of $z$ around $V=0$. As the applied bias voltage approaches zero, the tunnelling current will also tend toward zero, which is 


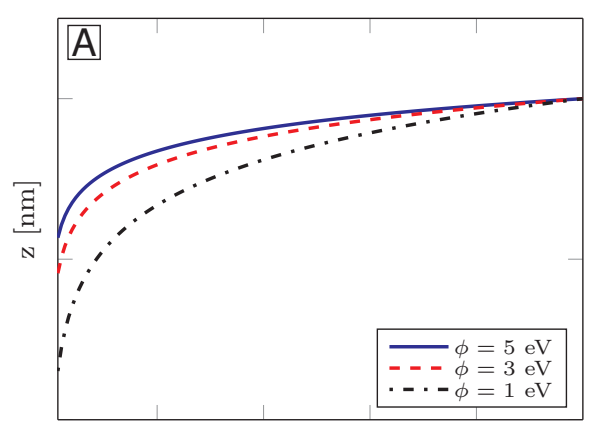

Bias $[\mathrm{V}]$

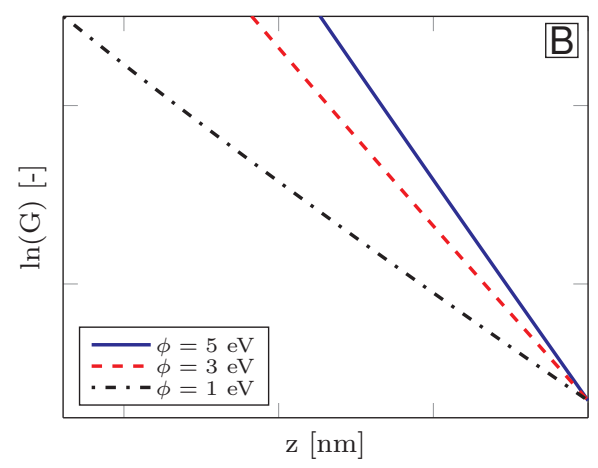

Figure 1.7: A) Simulated $z(V)$ curves for different barrier values. B) The logarithmic conductance plots corresponding to these $\mathrm{z}(\mathrm{V})$ curves.

compensated by the feedback loop by reducing the distance between the tip and the sample. This will inevitably lead to a tip crash at $V=0$, as the tunnelling current is equal to zero at this point. As such, a $\mathrm{z}(\mathrm{V})$ spectrum can only be recorded at one polarity at a time, unlike I(V) spectra which can be measured through $V=0$ without issues. Due to the logarithmic relationship between $z$ and $I$, the derivative $\frac{d z}{d V}$ provides a less intuitive picture than the $\frac{d I}{d V}$ signals obtained from $\mathrm{I}(\mathrm{V})$ spectroscopy. While the LDOS peaks can still be located in Figure 1.6D, they are not as pronounced as those in Figure 1.4D. However, when performing a thorough numerical analysis of the spectroscopy data, $\mathrm{I}(\mathrm{V})$ and $z(\mathrm{~V})$ measurements are equally useful. Chapter 3 provides an in-depth comparison between the two methods.

Figure 1.7 illustrates how $\mathrm{z}(\mathrm{V})$ spectroscopy can be used as an alternative for $\mathrm{I}(\mathrm{z})$ spectroscopy. Because the conductance is given by $G=\frac{I}{V}$, both types of measurement can be used to determine the conductance as a function of tip-sample distance. The only difference between the two methods is whether the conductance changes by actively changing the system parameters as is the case for $z(V)$ measurements, or as an indirect result of decreasing the tipsample distance as is the case for $\mathrm{I}(\mathrm{z})$ spectroscopy. Figure 1.5 and 1.7 show similar results, with the logarithmic conductance becoming more strongly dependent on $z$ as $\phi$ increases.

In the case of conductance measurements, $\mathrm{z}(\mathrm{V})$ measurements provide a significant advantage when compared with more conventional I(z) spectroscopy. Where $\mathrm{I}(\mathrm{z})$ carries a risk of inadvertent tip crashes due to system instability or poorly chosen $z$ ramping values, the closed-loop $z(V)$ method 
circumvents these risks. The inability to sweep the bias voltage across the $V=0$ point during $\mathrm{z}(\mathrm{V})$ spectroscopy is not relevant for conductance measurements, as conductance is polarity independent for limited bias voltages. A more thorough analysis of conductance measurements is given in Chapter 5 .

\subsubsection{Lock-in STS}

Unlike the STS methods introduced above, lock-in techniques have not seen widespread use until rather recently. ${ }^{29}$ The use of these techniques enables one to combine multiple measurements into a single procedure, making it easier to correlate certain observations and drastically cutting down on required measuring time. Multiple articles have been published on the subject of combining lock-in $\mathrm{I}(\mathrm{V})$ spectroscopy with regular topography measurements in order to obtain spatial parameter maps of a probed sample. ${ }^{30-32} \mathrm{In}$ at least one case, this has led to the resolution of a longstanding discussion between multiple research groups about the exact behaviour of electrons in a metallic wire system. ${ }^{31}$

Performing lock-in measurements requires the use of a lock-in amplifier to superimpose a periodic signal, also referred to as a modulation, onto either the bias voltage or the tip-sample distance of the STM system, e.g.

$$
V=V_{0}+\bar{V} \sin (\omega t)
$$

The system response to this modulation is then fed back into the lock-in amplifier. The output and input signals are subsequently correlated to determine the final lock-in output. Because the lock-in measurement should not interfere with the 'primary' measurement, it is vital that the STM feedback loop does not react to the modulation signal. This makes the modulation frequency $\omega$ a very important parameter in lock-in measurements, as it should meet two important requirements. Firstly, $\omega$ should be well above the cutoff frequency of the feedback loop in order to prevent any unwanted piezo response to the applied modulation. Secondly, the frequency should be well below the cutoff frequency of the system IV-converter, as the effect of the modulation on the tunnelling current would be undetectable otherwise. 


\subsection{Motivation}

Despite the fact that the STM has been used for over thirty years and has been the subject of numerous reviews, ${ }^{21,25,33,34}$ it is still mainly used as a qualitative vacuum imaging method. The behaviour of tunnelling junctions such as those found in STM systems is often described by a simplified version of the formula introduced by Simmons, e.g. Equation 1.2. While Equation 1.2 sufficiently describes the general relationships between tunnelling parameters (e.g. the logarithmic dependence of the tunnelling current on the tip-sample separation), it is insufficiently detailed to allow for a rigorous quantitative analysis of tunnelling measurements. Attempts at rigorous quantitative analysis often lead to results that defy theoretical explanation. ${ }^{35,36}$

Because of the risk of severe tip damage when bringing the tip in close proximity to the sample, the vast majority of STM and STS measurements are performed either with the feedback loop enabled (e.g. standard topography measurements) or with the tip in a fixed position (e.g. I(t), I(V) spectroscopy). However, holding the tip in a fixed position requires the use of a sample-and-hold system; a function that is not available for every STM setup.

The goal of the work described in this thesis can be roughly divided into two parts. Primarily, the measurements and theories described in this thesis were used to gain a greater understanding of the exact mechanisms underlying the quantum mechanical tunnelling process in different systems. In the process, the flaws inherent to conventionally used methods of analysis were analysed. Additionally, the insights garnered from this were used to develop and describe alternative types of spectroscopy that are not reliant on the use of a sample-and-hold system. These alternatives were then compared to their conventional counterparts in order to demonstrate their feasibility.

\subsection{Scope and Outline}

While the exact configuration of an STM system is hardly ever relevant when discussing the results obtained from it, reaching the point at which meaningful results can actually be obtained depends entirely on the used setup. Furthermore, proper interpretation of gathered data requires a thorough understanding of the working principles of the used equipment, as well as the underlying physics. As such, Chapter 2 provides an introduction to the ma- 
chines used to measure the data presented in this thesis, as well as the theoretical framework upon which the analysis of said data is based. Chapters 3, 4 and 5 describe work performed on a room-temperature, vacuum STM system in chronological order. These chapters mostly deal with alternative measurement modes and analytical interpretations that go beyond those conventionally used in literature. The final chapter deals with the comparison between standard vacuum junctions and ambient or liquid junctions.

Chapter 3 demonstrates the feasibility of using constant-current $\mathrm{z}(\mathrm{V})$ measurements to determine the local density of states (LDOS) of a probed sample; measurements that have conventionally been performed in constant-distance $\mathrm{I}(\mathrm{V})$ mode. Operating in $\mathrm{z}(\mathrm{V})$ mode eliminates the need for the inclusion of a sample-and-hold system in the STM, making it a widely accessible method. In addition, shortcomings of the conventionally used $\frac{d I}{d V}$ method of determining the LDOS are exposed, calling into question the validity of using this method at higher bias voltages.

Chapter 4 details the remarkable results obtained while performing Transition Voltage Spectroscopy (TVS) measurements on gold and platinum. Introduced as a method of obtaining the work function of a probed sample, the theory of TVS predicts a direct linear relationship between the tunnelling transition voltage and the inverse distance between the STM tip and the probed sample. Astoundingly, multiple measurements on different samples consistently show a completely opposite relationship, with the transition voltage being inversely proportional to the inverse tip-sample separation.

Spectroscopic measurements can also be used to extract information on the tunnelling barrier height, which in turn allows one to determine the work function of the probed sample. Chapter 5 compares the use of constantcurrent $\mathrm{z}(\mathrm{V})$ and current-distance $\mathrm{I}(\mathrm{z})$ spectroscopic conductance measurements for the determination of the local tunnelling barrier. While constantcurrent spectroscopy is very rarely used in the determination of the local tunnelling barrier, the results obtained from this method are very similar to those obtained from the more conventional $\mathrm{I}(\mathrm{z})$ method. In addition to determining the inverse decay length from both $z(V)$ and $I(z)$ conductance measurements, the development of a numerical fitting method also allows the decoupling and quantitative determination of the individual constituents that make up the inverse decay length, i.e. the local work function of the sample and the contribution of image charge effects.

The numerical fitting method and analysis model presented in Chapter 5 
provide a convenient way of determining the tunnelling gap parameters in a vacuum junction. In Chapter 6, this model is utilised to investigate the impact of the tunnelling environment on the junction parameters. Through the use of an electrochemical STM, tunnelling spectroscopy experiments were carried out in ambient conditions, as well as in a variety of polar and nonpolar solvents such as water, ethanol and cyclohexane. Despite the drastically lowered barriers in these systems, topographic and spectroscopic measurements remain quite possible in a large number of the investigated solvents.

\section{Bibliography}

[1] A. Sommerfeld \& H. Bethe. Handbüch der Physik von Geiger und Scheel, vol. 24/2 (Julius Springer-Verlag, 1933).

[2] J. C. Fisher \& I. Giaever. Tunneling Through Thin Insulating Layers. J. Appl. Phys. 32, 172-177 (1961).

[3] L. Canto, P. Gomes, R. Donangelo \& M. Hussein. Fusion and breakup of weakly bound nuclei. Phys. Rep. 424, 1 - 111 (2006).

[4] R. I. Cukier \& D. G. Nocera. Proton-Coupled Electron Transfer. Annu. Rev. Phys. Chem. 49, 337-369 (1998).

[5] K. Likharev. Single-electron devices and their applications. Proc. IEEE 87, 606-632 (1999).

[6] A. C. Seabaugh \& Q. Zhang. Low-Voltage Tunnel Transistors for Beyond CMOS Logic. Proc. IEEE 98, 2095-2110 (2010).

[7] A. M. Ionescu \& H. Riel. Tunnel field-effect transistors as energy-efficient electronic switches. Nature 479, 329-337 (2011).

[8] L. Esaki. New Phenomenon in Narrow Germanium $p-n$ Junctions. Phys. Rev. 109, 603-604 (1958).

[9] L. Esaki \& Y. Miyahara. A new device using the tunneling process in narrow p-n junctions. Solid-State Electron. 1, 13 - 21 (1960).

[10] G. Binnig, H. Rohrer, C. Gerber \& E. Weibel. Tunneling through a controllable vacuum gap. Appl. Phys. Lett. 40, 178-180 (1982). 
[11] G. Binnig, H. Rohrer, C. Gerber \& E. Weibel. Surface Studies by Scanning Tunneling Microscopy. Phys. Rev. Lett. 49, 57-61 (1982).

[12] W. A. Hofer, A. S. Foster \& A. L. Shluger. Theories of scanning probe microscopes at the atomic scale. Rev. Mod. Phys. 75, 1287-1331 (2003).

[13] D. J. Griffiths. Introduction to Quantum Mechanics (Pearson Prentice Hall, 2005).

[14] K. Gundlach. Zur berechnung des tunnelstroms durch eine trapezförmige potentialstufe. Solid-State Electron. 9, 949 - 957 (1966).

[15] J. G. Simmons. Generalized Formula for the Electric Tunnel Effect between Similar Electrodes Separated by a Thin Insulating Film. $J$. Appl. Phys. 34, 1793-1803 (1963).

[16] R. Holm. The Electric Tunnel Effect across Thin Insulator Films in Contacts. J. Appl. Phys. 22, 569-574 (1951).

[17] M. F. Crommie, C. P. Lutz \& D. M. Eigler. Confinement of Electrons to Quantum Corrals on a Metal Surface. Science 262, pp. 218-220 (1993).

[18] D. Eigler \& E. Schweizer. Positioning single atoms with a scanning tunnelling microscope. Nature 344, 524-526 (1990).

[19] I. B. M. Research. A Boy and His Atom (2013). URL http: //www.research.ibm.com/articles/madewithatoms.shtml. Accessed 30th April 2015.

[20] J. D. Bernal. Unknown Title. Proc. Roy. Soc. A 106 (1924).

[21] Y. Kuk \& P. J. Silverman. Scanning tunneling microscope instrumentation. Rev. Sci. Instrum. 60, 165-180 (1989).

[22] G. Binnig, K. H. Frank, H. Fuchs, N. Garcia, B. Reihl, H. Rohrer, F. Salvan \& A. R. Williams. Tunneling Spectroscopy and Inverse Photoemission: Image and Field States. Phys. Rev. Lett. 55, 991-994 (1985).

[23] A. Selloni, P. Carnevali, E. Tosatti \& C. D. Chen. Voltage-dependent scanning-tunneling microscopy of a crystal surface: Graphite. Phys. Rev. B 31, 2602-2605 (1985). 
[24] R. M. Feenstra. Scanning tunneling spectroscopy. Surf. Sci. 299/300, $965-979$ (1994).

[25] P. Samori. Scanning probe microscopies beyond imaging. J. Mater. Chem. 14, 1353-1366 (2004).

[26] A. van Houselt \& H. J. W. Zandvliet. Colloquium : Time-resolved scanning tunneling microscopy. Rev. Mod. Phys. 82, 1593-1605 (2010).

[27] B. S. Swartzentruber, A. P. Smith \& H. Jónsson. Experimental and Theoretical Study of the Rotation of Si Ad-dimers on the Si(100) Surface. Phys. Rev. Lett. 77, 2518-2521 (1996).

[28] B. S. Swartzentruber. Direct Measurement of Surface Diffusion Using Atom-Tracking Scanning Tunneling Microscopy. Phys. Rev. Lett. 76, 459-462 (1996).

[29] R. Wiesendanger. Scanning Probe Microscopy and Spectroscopy: Methods and Applications (Cambridge University Press, 1994).

[30] R. J. de Vries, A. Saedi, D. Kockmann, A. van Houselt, B. Poelsema \& H. J. W. Zandvliet. Spatial mapping of the inverse decay length using scanning tunneling microscopy. Appl. Phys. Lett. 92, $1741011-1741013$ (2008).

[31] R. Heimbuch, M. Kuzmin \& H. J. W. Zandvliet. Origin of the $\mathrm{Au} / \mathrm{Ge}(001)$ metallic state. Nat. Phys. 8, 697-698 (2012).

[32] A. Kumar, S. K. C. Palanisamy, J. M. Boter, C. Hellenthal, J. E. ten Elshof \& H. J. Zandvliet. Imaging of $\mathrm{Ti}_{0.87} \mathrm{O}_{2}$ nanosheets using scanning tunneling spectroscopy. Appl. Surf. Sci. 265, 201 - 204 (2013).

[33] P. K. Hansma \& J. Tersoff. Scanning tunneling microscopy. J. Appl. Phys. 61, R1-R24 (1987).

[34] L. A. Bottomley, J. E. Coury \& P. N. First. Scanning Probe Microscopy. Anal. Chem. 68, 185-230 (1996).

[35] M. L. Trouwborst, C. A. Martin, R. H. M. Smit, C. M. Guédon, T. A. Baart, S. J. van der Molen \& J. M. van Ruitenbeek. Transition Voltage Spectroscopy and the Nature of Vacuum Tunneling. Nano Lett. 11, 614-617 (2011). 
[36] K. Sotthewes, V. Geskin, R. Heimbuch, A. Kumar \& H. J. W. Zandvliet. Research Update: Molecular electronics: The single-molecule switch and transistor. APL Materials 2, 01070101 - 01070111 (2014). 



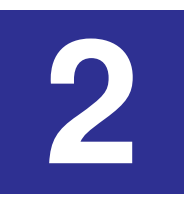

\section{Experimental setup and theory of electrochemical scanning tunnelling microscopy}
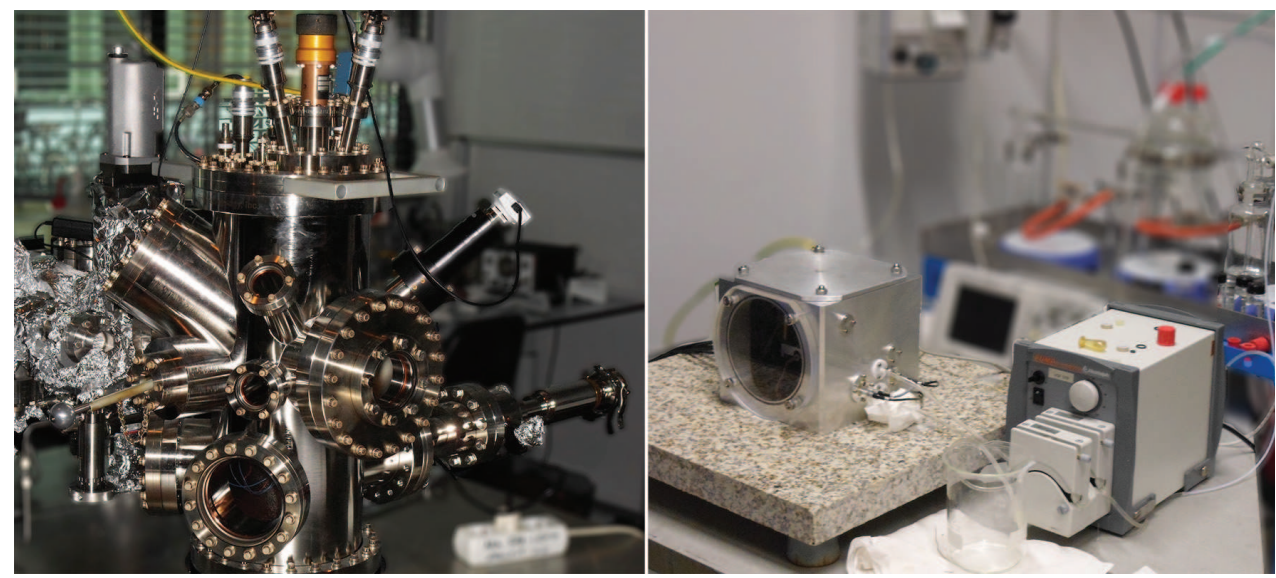

As described in the previous chapter, the STM enables a user to obtain highly detailed topographic and electronic information of a sample, provided that the system is functioning properly and external noise is minimised. In this chapter, the systems used in the realisation of this thesis will be described. Additionally, the basics of electrochemistry and electrochemical STM are included to provide additional insight into the challenges associated with performing scanning tunnelling experiments in liquid environment. 


\subsection{RHK UHV Variable Temperature STM}

The vacuum results presented in this thesis have been obtained using a UHV variable temperature STM such as the one shown in Figure 2.1. Labels indicate the following key components of the machine:

- The main chamber, which houses the actual STM module.

- The wobble stick, used to transfer the sample stage from the loadlock to the main chamber and vice versa.

- The flow cryostat, which can be used to cool the system down to approximately $40 \mathrm{~K}$.

- The current amplifier, which can be exchanged for alternative models to change the effective current range and bandwidth of the system.

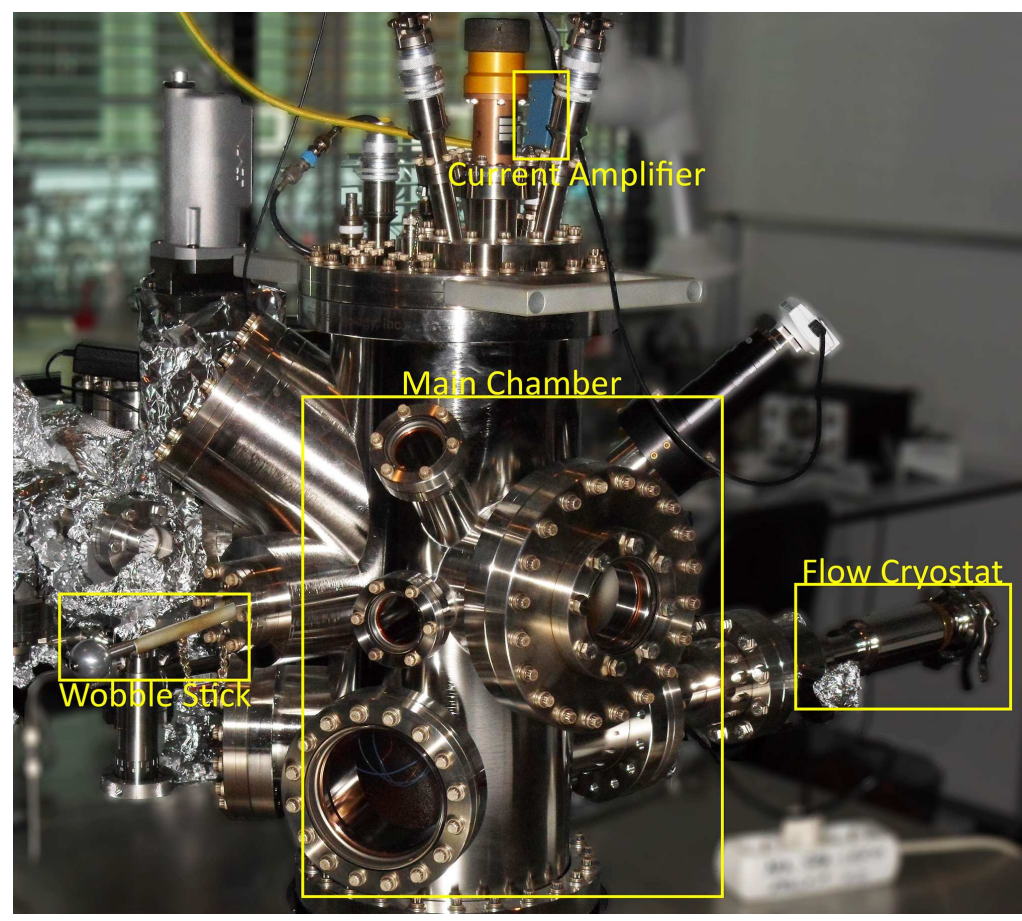

Figure 2.1: The RHK STM setup, with key components labelled. 

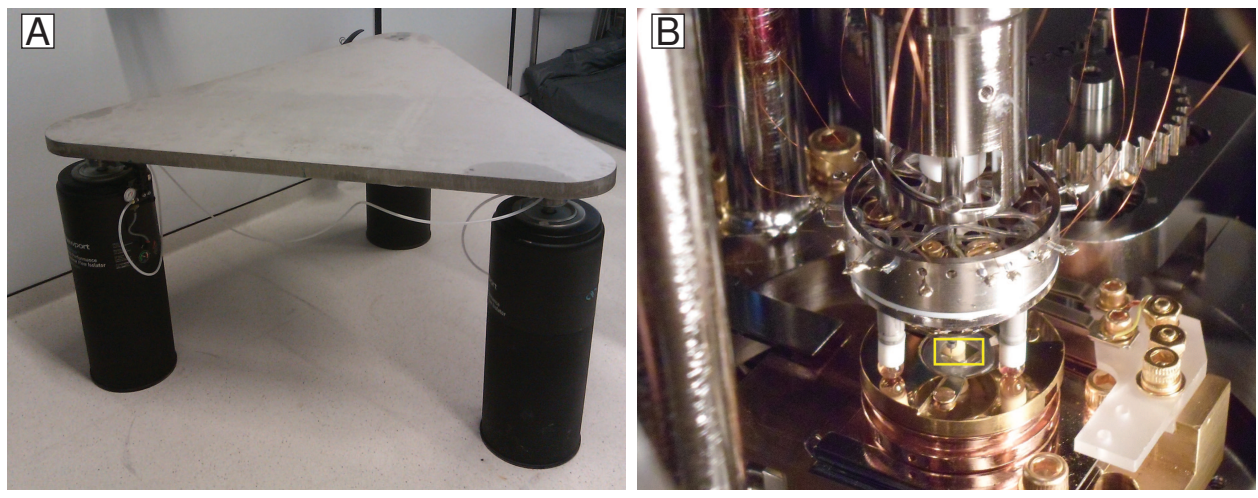

Figure 2.2: A) A metal slab supported by three laminar flow isolators. This support table was used for the ECSTM described in Section 2.2. B) The interior of the RHK UHV main chamber, showing the scan module and the piezo legs. The tip and sample are highlighted with a yellow outline.

In order to prevent contaminants present in the atmosphere from entering the STM main chamber, the loadlock and main chamber each have a separate system of vacuum pumps. Switching samples (and/or tips) is realised by using the loadlock as an intermediate stage. After placing the sample in the loadlock, the loadlock is then pumped down to a base pressure of approximately $1 \times 10^{-9}$ mbar. After reaching the desired pressure, the pressure valve between the chambers can be opened and the sample stage can then be transferred to the STM main chamber through the use of the wobble stick. In addition to providing protection from airborne contaminants, the vacuum in the main chamber also prevents acoustic vibrations from coupling into the STM and disrupting the measuring process.

To prevent mechanical vibrations from the environment from coupling into the STM and adversely impacting measurements, the STM chamber is mounted on a table supported by three laminar flow isolators, as shown in Figure 2.2A. This effectively causes the STM to 'float' above the ground, isolating it from minor vibrations transmitted via the ground such as those caused by nearby traffic, running pumps or seismic noise. Additional vibration isolation is provided through the use of eddy current dampers. 
The actual STM scanning unit is shown in Figure 2.2B. This type of scanner is known as a 'Beetle' model and is characterised by its approach procedure. In this configuration, the scanner piezo is positioned above the sample and supported by a cylindrical ramp resting on three individual piezo legs mounted on a baseplate. By applying a periodic sawtooth voltage ramp to the three piezo legs, they can be made to bend gradually in a certain direction before rapidly snapping back to a neutral state. The gradual bending of the piezos will cause the ramp to be rotated, leading to the scanner piezo being moved closer or further away from the sample, depending on the polarity of the applied sawtooth wave. Because the piezos return to their neutral position practically instantaneously, the ramp does not move along with them. This 'stick-slip' mechanism can therefore be utilised to effect the coarse approach of the STM tip.

The STM is controlled via an RHK SPM600 hardware/software module. The SPM600 hardware incorporates high voltage outputs for the control of the scanner and approach piezos, as well as numerous BNC connectors for the input and output of low voltage signals. It has multiple internal ZPI controllers that can be used to achieve feedback control of the system. The accompanying software provides control and read-out of basic topography and spectroscopy measurements, as well as more complex combined measurements. Acquired data is by default stored in the proprietary .SM4 format, but can also be exported to plain ASCII and most common graphics formats.

\subsection{RHK Rev9 ECSTM Setup}

The electrochemical measurements described in Chapter 6 have been obtained using the home-built setup shown in Figure 2.3, consisting of the actual STM setup and the electrochemical periphery. The following components are marked:

- The aluminium cube, which houses the electrochemical cell and the scan module.

- The hose pump, used to transport electrolyte from the vessel into the electrochemical cell and from the cell into the waste container.

- The electrolyte vessel, in which the electrolyte is continuously purged with argon in order to eliminate any oxygen that might be contained within. 


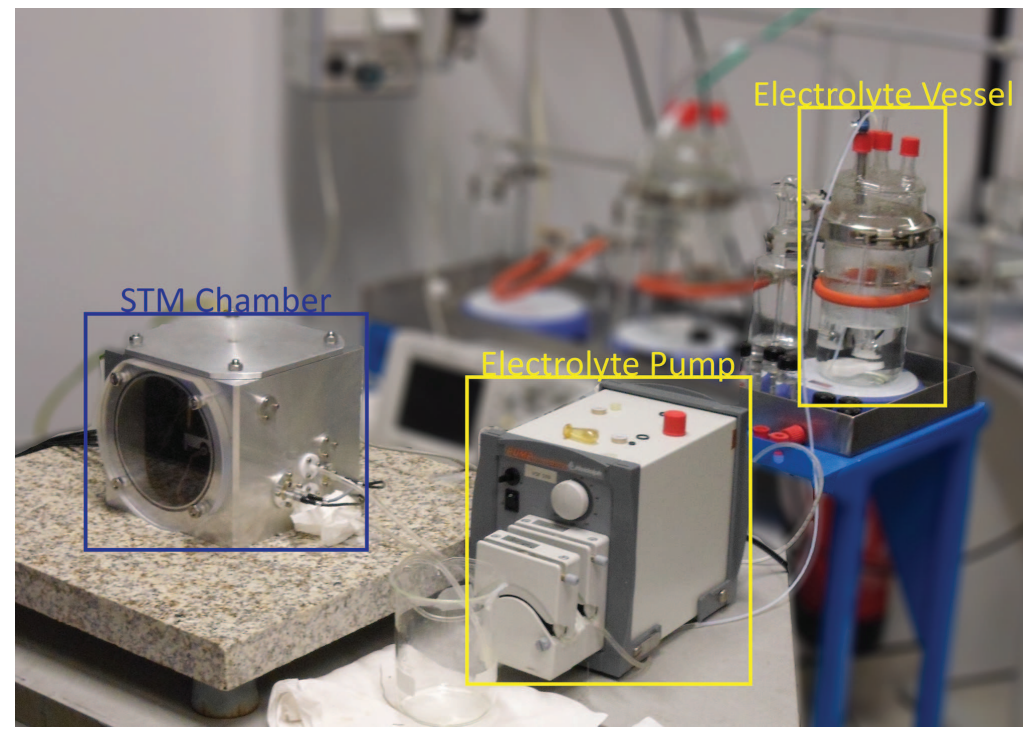

Figure 2.3: The ECSTM setup, with key components labelled.

As is the case for the RHK UHV setup, the ECSTM is placed on a table supported by laminar flow isolators in order to suppress mechanical noise from the direct environment of the microscope. Analogous to the main chamber of the UHV system, the actual ECSTM module is housed within an aluminium cube fitted with a plexiglass viewing window. In addition to the viewing window, the cube is fitted with several plugs to connect the STM to the controller, as well as three connections for Tygon ${ }^{\circledR}$ tubing for the inand outflow of electrolytes and the inflow of gases. When all nuts are properly fastened and all connectors are in place, the cube can be considered to be airtight. By maintaining a constant flow of an inert gas such as argon or nitrogen into the cube, the diffusion of oxygen into the system can be minimised.

The scan unit is of the 'Beetle' variety as described in the preceding section. The scan unit is equipped with a lifting cylinder, which can be used to lock the approach ramp into place or lower it onto the piezo legs on the baseplate. When the ramp is locked in place, the scan unit can be removed from the aluminium cube and placed in an external holder. This external holder is fitted with a USB camera to allow the user to alter the height of the tip with a high degree of accuracy. This procedure is necessitated by the limited approach range of the ramp. 


\subsubsection{Electrochemical Periphery}

The electrochemical cell shown in Figure 2.4A houses both the sample to be studied, as well as the electrolyte solution. The inner cell is made of Ketron ${ }^{\circledR}$, a material with a high chemical resistance and mechanical strength. Two wire-electrodes are affixed to the inner cell walls; a counter electrode (CE) used to pass current to or from the sample and a reference electrode (RE) used to measure the potential difference between the electrolyte solution and the sample. These electrodes are connected to an external bipotentiostat via a LEMO plug. The sample can be regarded as the working electrode (WE) and is held in place by a ball-and-socket screw mechanism and a Viton ${ }^{\circledR}$ sealing ring. This sealing ring prevents any electrolyte from seeping out of the inner cell and ensures that only the selected sample surface is exposed to the solution.

The electrochemical cell is mounted within the baseplate. In addition to the cell dock, the baseplate contains three piezo legs, three support pillars and two glass tubes. The glass tubes are used to pump electrolyte solutions into and out of the electrochemical cell, removing the need to open the system to refresh or change the electrolyte. The support pillars allow for easy placement of the scanning unit containing the STM tip. The piezo legs are used for the coarse approach of the STM tip towards the sample. The ECSTM utilises the same 'stick-slip' mechanism as the UHV STM, as described in Section 2.1 .

In order to minimise disruptive faradaic currents, the ECSTM tip is coated with an isolating polymer, leaving only the apex exposed to the electrolyte. Despite this precaution, it is still possible for the faradaic current to be orders of magnitude larger than the tunnelling current within certain potential ranges. An additional countermeasure to this problem is provided by incorporating a bipotentiostat setup in the ECSTM system. The bipotentiostat is used to define the potential between the RE and WE (the work potential) and to measure the corresponding current flowing between the CE and WE. Additionally, it allows the operator to define the tip potential between either the tip and the WE (the sample) or the tip and the RE. In the former case, the ECSTM operates in the same manner as a 'conventional' STM, with the tip bias being equal to the bias potential. This is because the sample is grounded, leading to the relation $V_{\text {tip }}=V_{\text {bias }}$, regardless of the work potential. In the latter case, a change in the work potential is matched by a corresponding change in the tip potential, so that the difference between the two is always 

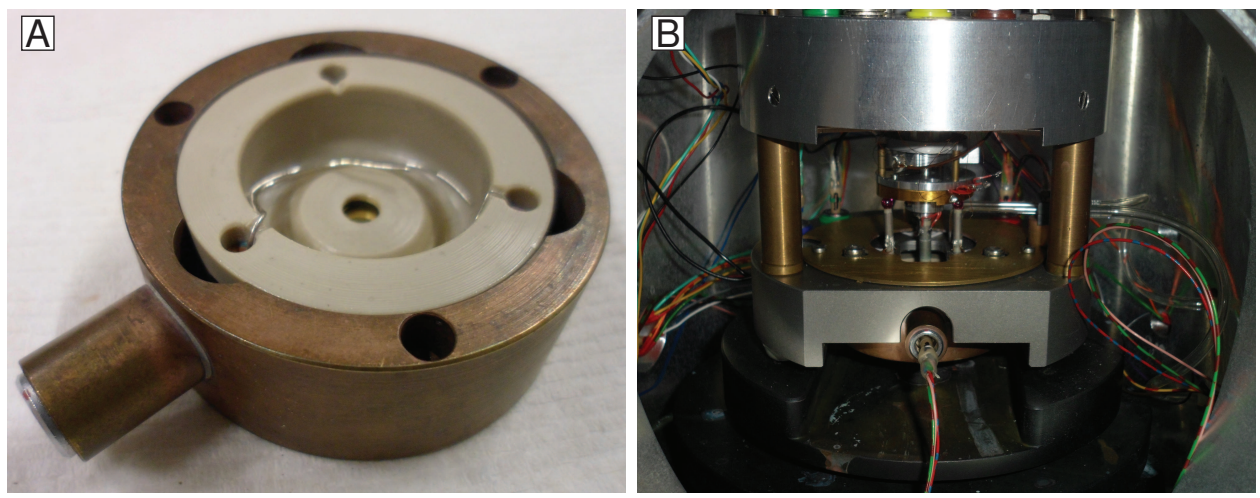

Figure 2.4: A) The electrochemical cell and cellholder. The platinum and silver wire electrodes are clearly visible. B) The ECSTM base plate, as seen through the viewing port. The electrochemical cell is mounted and the approach ramp is resting on the piezo legs.

equal to the set value desired by the operator. This can be useful when there is a limited potential window in which no significant faradaic current flows between the tip and the reference electrode. However, this mode makes it difficult to perform spectroscopic measurements in which the tip potential is swept, as this will also impact the work potential, leading to a change in the chemical processes occurring at the sample. An external sweep generator can be coupled to the bipotentiostat in order to generate a variety of potential waveforms in order to perform voltammetric measurements (see Section $2.3 .2)$.

Like the UHV STM, the ECSTM is controlled via a hardware/software module provided by RHK. However, the ECSTM uses a later iteration of the system, namely the Rev9 incarnation. The Rev9 software package has a modular design, allowing the user to (re)define a large variety of different procedures, ranging from coarse approach controls to topographic scanning and spectroscopy via a graphical programming interface. This also allows integration of the bipotentiostat controls with the STM controller, leading to a single integrated system for STM and electrochemical measurements. 


\subsection{Electrochemistry Basics}

Electrochemistry, as the name implies, deals with the combination of electrical and chemical effects, e.g. the production of electric current from chemical reactions or chemical changes due to the passing of an electric current. ${ }^{1}$ Electrochemistry occurs in nature (e.g. corrosion) and is used in a multitude of devices (e.g. batteries, displays) as well as industrial processes (e.g. electroplating and the production of aluminium and chlorine).

Rather than studying a single interface, electrochemistry deals with the study of collections of interfaces contained within an electrochemical cell or EC. Generally, an electrochemical cell consists of two electrodes, separated by at least one electrolyte phase. The cell potential is the difference in electric potential between the two electrodes and can be measured using a voltmeter. It is a measure of the energy available in the system to drive charge between the two electrodes. In most experiments, all the interesting reactions occur at a single electrode, which is referred to as the working electrode (WE). The reference electrode (RE) is often standardised by ensuring its composition is constant throughout the experiment, giving it a fixed potential. In more advanced electrochemical experiments, a so-called three electrode setup is utilised. This setup incorporates an additional electrode in its design; the auxiliary or counter electrode (CE). When using this setup, one applies (or measures) a current through the WE and $\mathrm{CE}$, while using the RE to monitor the potential of the WE. By preventing a current to be passed through the $\mathrm{RE}$, its potential can be prevented from changing, ensuring a stable reference potential for the WE.

Having a reference electrode at fixed potential allows one to control the potential of the working electrode with respect to the reference. This is equivalent to increasing or decreasing the amount of energy the electrons in the working electrode possess. By applying a negative voltage to the working electrode one can increase the energy of its electrons. This can lead to electrons transferring from the filled states of the working electrode into the vacant states of the species contained within the electrolyte. This flow of electrons from working electrode to solution is referred to as a reduction or cathodic current. Conversely, applying a positive voltage to the working electrode will lower the energy of its electrons, causing electrons from the electrolyte to flow into the vacant states of the working electrode. This current is referred to as an oxidation or anodic current. 
An electrochemical reaction consists of the transfer of charge and the chemical change of one or more reagents. A typical example would be the reduction of protons into hydrogen gas:

$$
2 \mathrm{H}^{+}(\mathrm{aq})+2 \mathrm{e}^{-}(\mathrm{aq}) \longrightarrow \mathrm{H}_{2}(\mathrm{~g})
$$

From this example it is apparent that there is a direct relationship between the amount of charge transferred between the electrodes and the amount of reactants consumed (or product generated). One can therefore obtain information on the reaction rate of a process by measuring the current (i.e. charge transferred per unit time) between the two electrodes. The exact relationship between the amount of charge transferred and the amount of product formed is given by Faraday's law:

$$
\text { Rate }\left(\mathrm{mol} \mathrm{s}^{-1}\right)=\frac{d N}{d t}=\frac{i}{n F},
$$

with $i$ the current in A, $n$ the stoichiometric number of electrons consumed in the reaction and $F=96485 \mathrm{C} \mathrm{mol}^{-1}$ the Faraday constant. Equation 2.2 gives the rate constant for a so-called homogeneous process in which the reaction takes places everywhere in the medium at a uniform rate. For electrochemical reactions occurring at the electrode, the rate constant is often dependent on mass-transfer and other surface effects. These reactions are called heterogeneous and can be described via a slightly different version of Faraday's law:

$$
\operatorname{Rate}\left(\mathrm{mol} / \mathrm{s} / \mathrm{cm}^{2}\right)=\frac{i}{n F A}=\frac{j}{n F} .
$$

Here $A$ is the surface area in $\mathrm{cm}^{2}$ and $j$ is the current density in $\mathrm{A} / \mathrm{cm}^{2}$. Note that Equation 2.3 gives the rate constant per unit area.

\subsubsection{Solid-liquid interface in electrochemistry}

A potential difference between the electrode and the electrolyte solution causes a redistribution of charge across the electrode-solution interface. This redistribution is analogous to the charge separation that occurs in a capacitor and gives rise to the formation of an electrical double layer at the electrodesolution interface. This double layer consists of two distinct layers; the inner layer and the diffuse layer. The inner layer (also called the compact, Helmholtz or Stern layer) contains specifically adsorbed species such as solvent 
molecules or ions. It consists of two distinct planes; the inner Helmholtz plane (IHP) and the outer Helmholtz plane (OHP). The electrical centres of the specifically adsorbed ions make up the IHP, whereas the solvated ions closest to the IHP make up the OHP. The solvated ions only have a longrange electrostatic interaction with the metal electrode due to the separation between the electrode surface and the OHP. These ions are called nonspecifically adsorbed ions and can be found in both the OHP and the diffuse layer, which extends into the bulk of the solution.

The formation of an electric double layer at the electrode-solution interface can have a distinct effect on the reaction rates of electrode processes. Additionally, the capacitive nature of the double layer gives rise to a charging current that can be significantly larger than the faradaic current associated with reduction or oxidation reactions.

\subsubsection{Electrochemical Methods}

When studying the electrochemical behaviour of a system, it is customary to apply a potential ramp which varies linearly with time and measure the corresponding current. This method is called Linear Sweep Voltammetry (LSV) and provides information about the chemical processes that take place in the system at certain potentials. By reversing the potential sweep after a certain period of time or at a certain potential, one can also measure the currents associated with the system's reverse reactions. This technique is referred to as Cyclic Voltammetry (CV) and is typically used to get qualitative or semi-quantitative information about the system.

Figure 2.5 shows an example of a $\mathrm{CV}$ measurement using $0.5 \mathrm{M} \mathrm{H}_{2} \mathrm{SO}_{4}$ as electrolyte and HOPG as the working electrode. Three distinct peaks can be seen in the graph, each corresponding to a different electrochemical reaction. When the potential is increased from $0 \mathrm{~V}$ to $1.6 \mathrm{~V}$ at a constant rate, the measured current increases slowly until the applied potential passes $1.4 \mathrm{~V}$, at which point the measured current increases rapidly. This anodic current is likely caused by the formation and adsorption of $\mathrm{O}_{2}$ via the following reaction:

$$
2 \mathrm{H}_{2} \mathrm{O}(\mathrm{l}) \longrightarrow \mathrm{O}_{2}(\mathrm{~g})+4 \mathrm{H}^{+}(\mathrm{aq})+4 \mathrm{e}^{-}(\mathrm{aq}) .
$$

When the applied potential is swept from its maximum positive value back towards zero, the anodic current rapidly decreases and eventually changes into a cathodic current around $1.45 \mathrm{~V}$. This cathodic current can be linked 


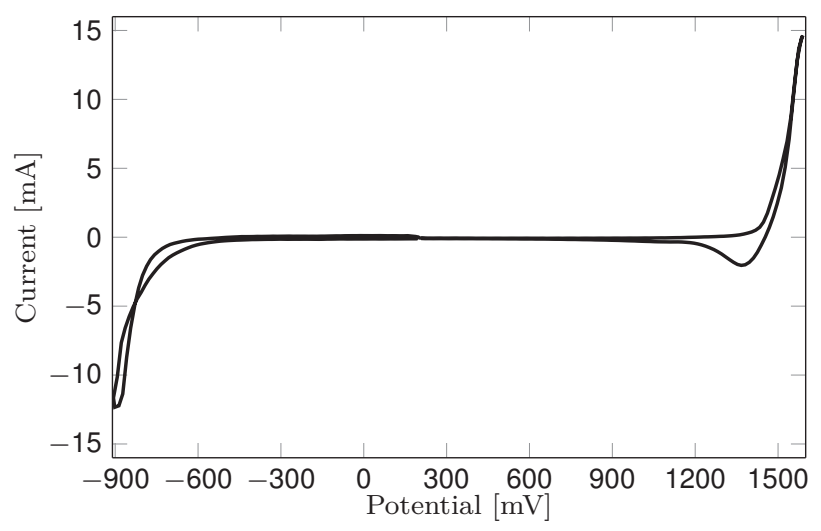

Figure 2.5: Cyclic voltammetry measurement of a $0.5 \mathrm{M} \mathrm{H}_{2} \mathrm{SO}_{4} / \mathrm{HOPG}$ system. The different current peaks correspond to different chemical processes.

to the desorption of the formed oxygen and the subsequent reversal of the reaction shown in 2.4 , i.e.

$$
\mathrm{O}_{2}(\mathrm{~g})+4 \mathrm{H}^{+}(\mathrm{aq})+4 \mathrm{e}^{-}(\mathrm{aq}) \longrightarrow 2 \mathrm{H}_{2} \mathrm{O}(\mathrm{l})
$$

Once the reagents are depleted, the reaction will cease, as will the flow of the cathodic current. Sweeping the applied potential into the negative voltage range will eventually lead to a very high cathodic current. This current is associated with the formation of hydrogen gas $\left(\mathrm{H}_{2}\right)$ via the following reaction:

$$
2 \mathrm{H}^{+}(\mathrm{aq})+2 \mathrm{e}^{-}(\mathrm{aq}) \longrightarrow \mathrm{H}_{2}(\mathrm{~g})
$$

Because the formed hydrogen gas escapes from the electrochemical cell, no reverse reaction occurs on reversing the potential sweep direction. This explains the absence of an anodic current peak in the negative potential range in Figure 2.5.

The scan rate (i.e. how fast the applied potential changes in time) has a significant effect on the result of an LSV or CV measurement. Figure 2.6 shows a number of CV measurements of $0.5 \mathrm{M} \mathrm{H}_{2} \mathrm{SO}_{4}$ on HOPG taken at different scan rates. From the figure, it is directly apparent that the maximum electrochemical current is proportional to the scan rate used during the measurement. This phenomenon can be understood by considering the limiting factors for the reactions occurring at the electrode interface. The amount 


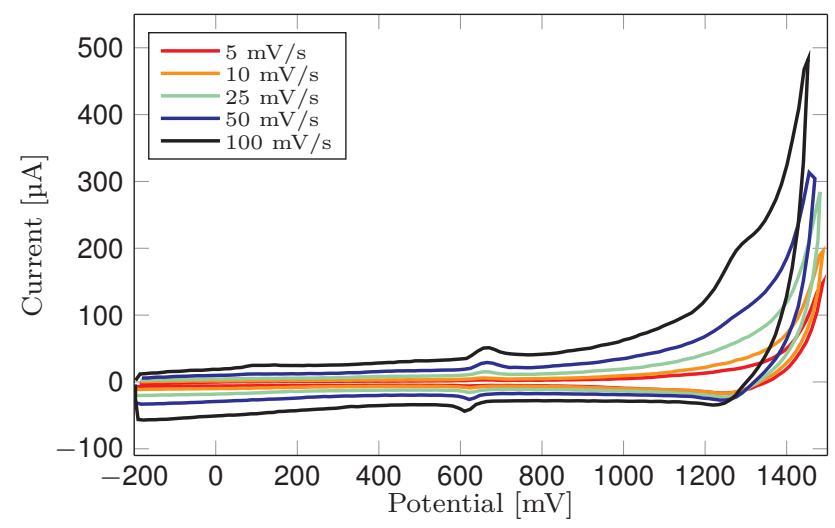

Figure 2.6: Cyclic voltammetry measurement of a $0.5 \mathrm{M} \mathrm{H}_{2} \mathrm{SO}_{4} / \mathrm{HOPG}$ system. The different curves correspond to different scan rates. The features around $600 \mathrm{mV}$ correspond to the formation and dissolution of hydroquinones. ${ }^{2}$

of current transferred is dependent on the rate of reaction, which in turn is dependent on the formation of a diffuse layer in the solution (Section 2.3.1). When doing experiments within a constant voltage range, a lower scan rate will lead to a longer experiment duration. This means that the diffuse layer will extend further away from the electron surface when compared with a similar experiment with a higher scan rate. Because the diffuse layer inhibits the transport of reactants towards the electrode surface, a larger diffuse layer will lead to lower reaction and electron transfer rates. This manifests itself in lower peak currents for CV measurements conducted at lower scan rates. This same line of reasoning can be used to explain the increased hysteresis for faster sweeps.

In addition to altering the height of the current peaks, changing the scan rate may also influence their peak potential. This happens when increasing the scan rate causes it to become 'fast' with respect to the reaction kinetics, effectively changing the limiting mechanism of the reaction. When the reaction is limited by charge transfer kinetics, establishing an equilibrium at the electrode surface takes longer, meaning that the current takes longer to 'respond' to the applied potential. Processes that have a constant peak potential are called reversible or Nernstian, whereas processes that do not are called quasireversible or irreversible. 


\subsection{Introduction to Electrochemical STM}

After its initial discovery in $1981,{ }^{3}$ the STM could only be operated in UHV conditions. However, it took only a few years before the technique was adapted for use in aqueous environments by Sonnenfeld and Hansma in $1986{ }^{4}$ Another two years later, Itaya and Tomita ${ }^{5}$ reported their development of an STM system that could be operated under potentiostatic electrochemical conditions. This development enabled electrochemists to image the electrode surface in situ and, by doing so, study the effect of surface structures on the reactions occurring at the electrode. Using STM in aqueous environments to study electrochemical reactions in situ is referred to as electrochemical scanning tunnelling microscopy (abbreviated as both ESTM and ECSTM in literature).

\subsubsection{Tunnelling in aqueous environments}

The presence of an aqueous electrolyte in the ECSTM system has a marked influence on the tunnelling process, lowering the effective potential barrier with a few $\mathrm{eV}$ and thereby increasing the maximum tunnelling distance. Different models have been used in literature. The simplest model treats the tunnelling process in aqueous environments in the same manner as the traditional UHV STM process. However, there have been multiple publications that support a somewhat more complicated model.

Song et al. ${ }^{6}$ noted that for thin interfacial water layers the tunnelling current accounts for the vast majority of charge transfer between the tip and the sample. For thicker water layers, the charge transfer becomes a nonexponential function of electrode potential, indicating the increased contribution of electrochemical currents to the total current. In 2003, Hugelmann and Schindler ${ }^{7}$ showed experimentally that both the tunnelling barrier and tunnelling current oscillate periodically as a function of tip distance. They ascribed this phenomenon to the formation of interfacial water layers between the tip and the sample. These water layers facilitate electron transport and lower the effective tunnelling barrier. Light emission STM studies carried out by Boyle et al. ${ }^{8}$ suggest that currents in aqueous environment do not solely depend on tunnelling. When operating in constant-current mode, light emission was significantly reduced for higher humidity levels, due to an increase in tunnelling distance. The authors stated that tunnelling was the only charge transfer mechanism that could lead to light emission, concluding that the in- 
creased humidity led to the formation of larger water bridges, in turn leading to alternative charge transfer mechanisms.

\subsubsection{ECSTM Operational Principle}

The operational principle of the ECSTM is very similar to that of a UHV STM system. The scanning tip consists of a needle of conducting, chemically inert material, typically tungsten or platinum-iridium, sharpened to have an apex of a single atom wide. The tip is brought into close proximity of the sample (the working electrode in the case of ECSTM) through the use of piezoelectric actuators whose dimensions can be altered by applying an electric potential to them. Tunnelling is achieved when the tip and sample are sufficiently close together. Once in tunnelling, the same procedures that are described in Chapter 1 are available for use in the ECSTM system.

There are a few subtle differences between ECSTM and regular STM setups. In ECSTM, the potential difference between the working electrode and the reference electrode determines the types of chemical reactions that can take place, as well as the rate at which these reactions take place. Because the tunnelling current between the tip and the sample is determined by their potential difference, it is important to be able to control their individual potentials separately. This is done with a bipotentiostat. Itaya and Tomita ${ }^{5}$ were the first to incorporate a bipotentiostat in an STM setup to carry out in situ measurements in a potentiostatic electrochemical environment. Their setup incorporated four distinct electrodes; the STM tip, a counter electrode, a reference electrode and the sample to be studied, which can be regarded as the working electrode.

The aqueous environment in which the ECSTM tip resides gives rise to a faradaic current that can be several times larger than the tunnelling current between the tip apex and the sample. To prevent these faradaic currents from obscuring the measurements, the tip is insulated with a chemically inert glass or polymer, leaving only the apex exposed. Despite the insulating coating around the tip, formation of an electrical double layer (see Section 2.3.1) still poses a challenge when performing spectroscopic measurements in an electrochemical environment. The capacitance of the double layer leads to a hysteresis in measured $\mathrm{I}(\mathrm{V})$ curves and the charging current obscures the correct measuring of the tunnelling current. Abadal et al. reported on a possible solution to this problem in $1996 .{ }^{9}$ Initially, the spectrum is measured in the same manner one would normally use. After this, the tip is retracted 
from the sample so that there is no longer any tunnelling current. The measurement is then repeated, after which the results of both measurements are subtracted from one another. The net result is a plot of the tunnelling current as a function of the bias voltage.

\section{Bibliography}

[1] A. J. Bard \& L. R. Faulkner. Electrochemical Methods: Fundamentals and Applications (John Wiley \& Sons, Inc., 2001), second edn.

[2] H.-S. Choo, T. Kinumoto, M. Nose, K. Miyazaki, T. Abe \& Z. Ogumi. Electrochemical oxidation of highly oriented pyrolytic graphite during potential cycling in sulfuric acid solution. J. Power Sources 185, $740-$ 746 (2008).

[3] G. Binnig, H. Rohrer, C. Gerber \& E. Weibel. Tunneling through a controllable vacuum gap. Appl. Phys. Lett. 40, 178-180 (1982).

[4] R. Sonnenfeld \& P. Hansma. Atomic-resolution microscopy in water. Science 232, 211-213 (1986).

[5] K. Itaya \& E. Tomita. Scanning tunneling microscope for electrochemistry - a new concept for the in situ scanning tunneling microscope in electrolyte solutions. Surf. Sci. 201, L507-L512 (1988).

[6] M.-B. Song, J.-M. Jang, S.-E. Bae \& C.-W. Lee. Charge Transfer through Thin Layers of Water Investigated by STM, AFM, and QCM. Langmuir 18, 2780-2784 (2002).

[7] M. Hugelmann \& W. Schindler. Tunnel barrier height oscillations at the solid/liquid interface. Surf. Sci. 541, L643-L648 (2003).

[8] M. G. Boyle, J. Mitra \& P. Dawson. The tip-sample water bridge and light emission from scanning tunnelling microscopy. Nanotechnology $\mathbf{2 0}$, 335202 (2009).

[9] G. Abadal, F. Pérez-Murano, N. Barniol, X. Borrisé \& X. Aymerich. A new method to perform in situ current voltage curves with an electrochemical scanning tunnelling microscope. Ultramicroscopy 66, 133-139 (1996). 



\section{Determining the local density of states in the constant current scanning tunnelling microscopy mode*}
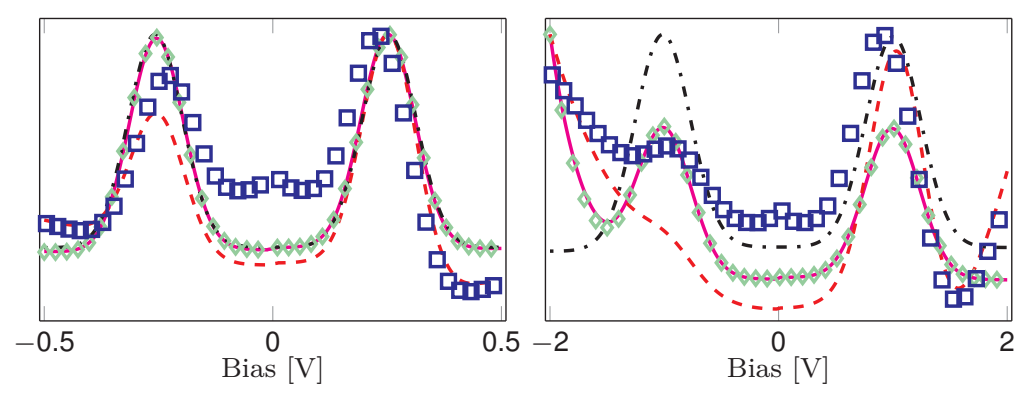

An alternative scheme to determine the local density of states (LDOS) of a sample using data obtained via Scanning Tunnelling Spectroscopy (STS) is introduced in this chapter. Using either the tunnelling current as a function of applied bias voltage or the tip-sample separation as a function of applied bias voltage, the LDOS can be determined via a numerical fitting algorithm. This fitting algorithm makes use of the one-dimensional Simmons tunnel barrier model without introducing any further mathematical approximations. By ways of a simulated LDOS, the proposed method is compared to existing LDOS extraction methods for both positive and negative biases and the differences between the methods are discussed.

${ }^{*}$ Published as C. Hellenthal, R. Heimbuch, K. Sotthewes, E.S. Kooij and

H.J.W. Zandvliet, Phys. Rev. B, 88(3), 035425 (2013) 


\subsection{Introduction}

Since its development in $1981,{ }^{1}$ the Scanning Tunnelling Microscope (STM) has been used extensively for the research of a large variety of substrates. In addition to the ability of providing high-resolution topography images of conducting substrates, the STM also provides limited information on the electronic and chemical composition of a sample by means of Scanning Tunnelling Spectroscopy (STS). Several types of STS measurements have been described and applied, and each type provides insight into different aspects of the studied sample. ${ }^{2}$ For example, during I(z) spectroscopy, the dependence of the tunnelling current $I$ on the tip-sample separation $z$ is measured while the applied tip-sample bias $V$ is kept constant. The curves obtained from these measurements can be used to determine the local work function and as such provide information on the electronic properties of the material under consideration. Performing I(t) spectroscopy, i.e. measuring the tunnelling current as a function of time, gives information on surface dynamics ${ }^{3}$ and Inelastic Electron Tunnelling Spectroscopy (IETS) can be used to reveal the vibrational modes and energies of a single absorbed molecule. ${ }^{4}$ One of the commonly used spectroscopic modes is $\mathrm{I}(\mathrm{V})$ spectroscopy, which can be used to determine the local density of states (LDOS) of a sample. The determination of the LDOS via spectroscopy is the focus of the remainder of this chapter.

During conventional $\mathrm{I}(\mathrm{V})$ spectroscopy, the tunnelling current is measured as a function of the applied sample bias which is swept over a certain voltage range. While performing these measurements, the feedback loop is switched off, effectively ensuring that the distance between the tip and the sample is kept constant. This is done by ways of a sample-and-hold circuit present in the STM electronics. This method of spectroscopy was pioneered by Feenstra et al. to study the $\mathrm{Si}(111) 2 \times 1$ surface. ${ }^{5}$ The obtained I(V) trace can be used to (numerically) determine the differential conductivity $\frac{d I}{d V}$. The differential conductivity is closely tied to the LDOS of a sample, which in turn provides information on the electronic and chemical properties of the sample. To obtain the highest possible level of detail from the differential conductivity, and because the absolute value of the differential conductivity depends on the chosen current setpoint, the signal is often normalised. A number of normalisation methods have been investigated in the past, starting with the method of Stroscio et al. who divided the differential conductivity by the total con- 
ductivity. ${ }^{6}$ An alternative approach to the normalisation of the differential conductivity involves the use of a tunnelling probability function, which is dependent on the contact area and separation between tip and surface and the densities of states of both the tip and the sample. ${ }^{7}$

Not all STM setups are equipped with a sample-and-hold functionality, necessitating the use of an alternative method of obtaining the differential conductivity of a sample. One such alternative method involves the use of a lock-in amplifier. By modulating the applied bias voltage with a high frequency, low amplitude signal and measuring the response of the tunnelling current to this modulation, it is possible to obtain the differential conductivity while measuring in constant current mode, i.e. in a closed-loop configuration. By choosing a modulation frequency well above the cutoff frequency of the feedback loop, one can simultaneously obtain both the differential conductivity as well as the non-constant tip-sample separation as a function of applied bias voltage. This technique has previously been applied to characterise the $\mathrm{Cu}(111)$ surface. $^{8}$

Recently, a method of determining the LDOS based solely on $z(V)$ data was described by Pronschinske et al. ${ }^{9}$ Normalising the $\mathrm{z}(\mathrm{V})$ data by using logarithmic derivatives was shown to yield LDOS peak positions with an accuracy of $0.1 \mathrm{eV}$. However, this method was only demonstrated for positive bias voltages.

Based on the above observations, the aim of this chapter is to introduce a new way of determining the LDOS of a given sample by using constant current $z(V)$ spectroscopy data. First, an alternative application of the Simmons model to determine the LDOS from either $\mathrm{I}(\mathrm{V})$ or $z(\mathrm{~V})$ measurements is introduced. Through the use of a simulated LDOS, this new method is then compared to the established way of determining the LDOS based on I(V) data. Through the comparison of the obtained results, the feasibility of determining the LDOS based solely on $\mathrm{z}(\mathrm{V})$ measurements is demonstrated.

\subsection{Model}

\subsubsection{Direct calculation}

The tunnelling current as a function of applied bias voltage $V$ and tip-sample separation $z$ can be approximated by the one-dimensional model of the tunnel barrier introduced by Simmons in $1963 .{ }^{10}$ In this model, the tunnelling 
current is given by

$$
I(z, V)=\int_{0}^{e V} \rho_{s}(E) \rho_{t}(E-e V) T(z, V, E) d E,
$$

where $\rho_{s}$ and $\rho_{t}$ are the densities of states of the sample and tip, respectively. The energy of the states participating in the tunnelling process is denoted by $E$. The transmission coefficient $T$ is given by

$$
T(z, V, E)=\exp \left(-\frac{2 \sqrt{2 m}}{\hbar} z \sqrt{\phi+\frac{e V}{2}-E}\right),
$$

where $m$ is the electron mass, $\hbar$ is the reduced Planck or Dirac constant and $\phi$ is the tunnel barrier height. ${ }^{11}$

When performing $\frac{d I}{d V}$ measurements in closed-loop (i.e. constant setpoint current) while applying a high-frequency bias modulation, the measured signal will have the following form:

$$
\frac{d I(z(V), V)}{d V}=\frac{d}{d V} \int_{0}^{e V} \rho_{s}(E) \rho_{t}(E-e V) T(z(V), V, E) d E .
$$

Evaluating this expression leads to

$$
\begin{aligned}
\frac{d I(z(V), V)}{d V} & =\int_{0}^{e V} \frac{d}{d V} \rho_{s}(E) \rho_{t}(E-e V) T(z(V), V, E) d E \\
& +e \rho_{s}(e V) \rho_{t}(0) T(z(V), V, e V) .
\end{aligned}
$$

The next step is the evaluation of the derivative of the transmission coefficient with respect to $V$. The total derivative of $T$ with respect to $V$ can be written as

$$
\frac{d}{d V} T(z(V), V, E)=\frac{\partial T(z(V), V, E)}{\partial V}+\frac{\partial T(z(V), V, E)}{\partial z} \frac{\partial z(V)}{\partial V} .
$$


Taking the partial derivatives of Equation 3.2 leads to:

$$
\begin{aligned}
\frac{\partial T(z(V), V, E)}{\partial V} & =\frac{\partial}{\partial V} \exp \left(-\frac{2 \sqrt{2 m}}{\hbar} z(V) \sqrt{\phi+\frac{e V}{2}-E}\right) \\
& \approx-\frac{e}{2} \frac{\frac{2 \sqrt{2 m}}{\hbar} z(V)}{2 \sqrt{\phi}} \exp \left(-\frac{2 \sqrt{2 m}}{\hbar} z(V) \sqrt{\phi+\frac{e V}{2}-E}\right) \\
& \approx-\frac{\sqrt{2 m} e z(V)}{2 \hbar \sqrt{\phi}} T(z(V), V, E)
\end{aligned}
$$

and

$$
\begin{aligned}
\frac{\partial T(z(V), V, E)}{\partial z} & =\frac{\partial}{\partial z(V)} \exp \left(-\frac{2 \sqrt{2 m}}{\hbar} z \sqrt{\phi+\frac{e V}{2}-E}\right) \\
& \approx-\frac{2 \sqrt{2 m}}{\hbar} \sqrt{\phi} \exp \left(-\frac{2 \sqrt{2 m}}{\hbar} z(V) \sqrt{\phi+\frac{e V}{2}-E}\right) \\
& \approx-\frac{2 \sqrt{2 m}}{\hbar} \sqrt{\phi} T(z(V), V, E) .
\end{aligned}
$$

Using the mean value theorem for integrals, the following approximation has been made: $\sqrt{\phi+\frac{e V}{2}-E} \approx \sqrt{\phi}$. This approximation was previously used by Koslowski et al. and greatly simplifies the analytical evaluation of the integral. ${ }^{12}$ Combining Equations 3.6 and 3.7 with Equation 3.4 and assuming $\rho_{t}(E-e V)$ is a slowly varying function of $V$ (i.e. $\left.\frac{d}{d V} \rho_{t}(E-e V) \approx 0\right)$ then leads to:

$$
\begin{aligned}
\frac{d I(z(V), V)}{d V} & =\int_{0}^{e V}\left[\rho_{s}(E) \rho_{t}(E-e V)\left(-\frac{\sqrt{2 m} e z(V)}{2 \hbar \sqrt{\phi}}-\frac{\partial z(V)}{\partial V} \frac{2 \sqrt{2 m}}{\hbar} \sqrt{\phi}\right)\right. \\
& \times T(z(V), V, E)] d E+e \rho_{s}(e V) \rho_{t}(0) T(z(V), V, e V) .
\end{aligned}
$$

Recalling Equation 3.1, as well as the fact that measurements are performed at constant current, this simplifies to:

$$
\begin{aligned}
\frac{d I(z(V), V)}{d V} & =e \rho_{s}(e V) \rho_{t}(0) T(z(V), V, e V) \\
& -\left(\frac{\sqrt{2 m} e z(V)}{2 \hbar \sqrt{\phi}}+\frac{2 \sqrt{2 m}}{\hbar} \frac{\partial z(V)}{\partial V} \sqrt{\phi}\right) I_{0}
\end{aligned}
$$




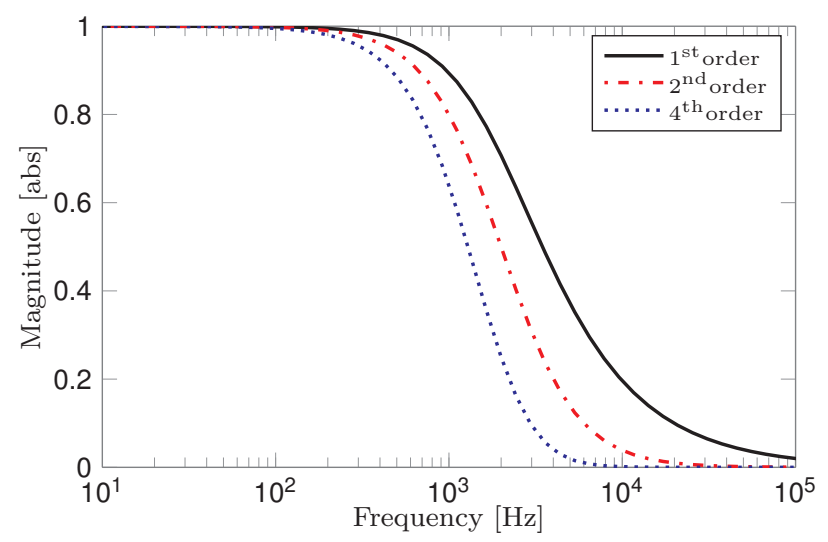

Figure 3.1: Frequency response of different order RC filters with a cutoff frequency of $2 \mathrm{kHz}$.

Rearranging this formula gives the expression for the density of states of the sample:

$$
\begin{aligned}
\rho_{s}(e V) & =\frac{1}{\rho_{t}(0) e T(z(V), V, E)} \\
& \times\left(\frac{d I(z(V), V)}{d V}+\left[\frac{\sqrt{2 m} e z(V)}{2 \hbar \sqrt{\phi}}+\frac{2 \sqrt{2 m}}{\hbar} \frac{\partial z(V)}{\partial V} \sqrt{\phi}\right] I_{0}\right) .
\end{aligned}
$$

The $\frac{\partial z(V)}{\partial V}$ term signifies the change in tip-sample separation based on the applied bias modulation. If the modulation frequency is well above the cutoff frequency of the feedback electronics, the feedback system will be unable to compensate for the applied modulation bias and this term can be neglected. ${ }^{13}$ What constitutes 'well above the cutoff frequency' depends entirely on the transfer function of the feedback system that is used. Special care should be taken when dealing with systems with a smooth, low-order transfer function, as marginally exceeding the cutoff frequency in these cases will not be sufficient to entirely eliminate the $\mathrm{z}(\mathrm{V})$ response of the feedback loop as is schematically indicated in Figure 3.1. Choosing a modulation frequency in the transient region of the frequency response curve will lead to partial contributions of the $\frac{d I(z(V), V)}{d V}$ and $\frac{\partial z(V)}{\partial V}$ terms, leading to potentially large errors in the determined LDOS. Assuming the modulation frequency is high 
enough, Equation 3.10 simplifies to

$$
\rho_{s}(e V)=\frac{1}{\rho_{t}(0) e T(z(V), V, E)}\left(\frac{d I(z(V), V)}{d V}+\frac{\sqrt{2 m} e z(V)}{2 \hbar \sqrt{\phi}} I_{0}\right),
$$

which is analogous to the expression previously derived by Ziegler et al. ${ }^{13}$

The other limiting case is a constant current measurement with a bias modulation frequency significantly below the cutoff frequency of the STM feedback electronics or no modulation bias at all. In this case, the total derivative $\frac{d I(z(V), V)}{d V}$ vanishes, but the partial derivative $\frac{\partial z(V)}{\partial V}$ does not. In this case, Equation 3.10 simplifies to

$$
\rho_{s}(e V)=\frac{1}{\rho_{t}(0) e T(z(V), V, E)}\left(\frac{\sqrt{2 m} e z(V)}{2 \hbar \sqrt{\phi}}+\frac{2 \sqrt{2 m}}{\hbar} \frac{\partial z(V)}{\partial V} \sqrt{\phi}\right) I_{0},
$$

which is consistent with the formula previously reported by Pronschinske et $a l .{ }^{9}$

For measurements performed in an open-loop configuration, $z$ will be constant and $I$ will vary with the applied sample bias, leading to a somewhat simpler version of Equation 3.10:

$$
\rho_{s}(e V)=\frac{1}{\rho_{t}(0) e T(z, V, E)}\left(\frac{d I(z, V)}{d V}+\frac{\sqrt{2 m} e z_{0}}{2 \hbar \sqrt{\phi}} I(V)\right) .
$$

This formula can be used to determine the LDOS from a conventional I(V) spectroscopy measurement, with the second term often having a very minor contribution to the total LDOS.

\subsubsection{LDOS fitting method}

The formulas in the preceding section give a simple and direct way of calculating the LDOS of a sample given the appropriate $\mathrm{I}(\mathrm{V})$ and $\mathrm{z}(\mathrm{V})$ data. However, the derivation of these formulas from Equation 3.1 introduces a number of approximations, most notably in Equations 3.6 and 3.7. As will be demonstrated in the following section, these approximations can be circumvented by working directly from Equation 3.1.

When working in constant height mode, the proposed method works by fitting the LDOS to the current measured in a standard I(V) experiment. 
Denoting the measured current by $I_{m}(V)$ and the constant tip-sample separation by $z_{0}$, the following error function can be defined:

$$
\chi=\left|I_{m}(V)-\int_{0}^{e V} \rho(E) T\left(z_{0}, V, E\right) d E\right| .
$$

Here, $\rho$ is the convolved density of states of both tip and sample. Through further analysis, the LDOS of tip and sample can be deconvoluted ${ }^{14}$ or the LDOS of the tip can simply be assumed to be constant. ${ }^{13}$ By using a numerical fitting algorithm, $\rho$ can be varied until the error function converges to its minimum value, which will ideally be equal to zero.

The only variables needed for this method are $I, z$ and $V$. This makes both $\mathrm{I}(\mathrm{V})$ as well as $\mathrm{z}(\mathrm{V})$ spectroscopy viable methods of determining the LDOS. When performing (constant current) $\mathrm{z}(\mathrm{V})$ spectroscopy, Equation 3.14 has to be altered slightly into the following form:

$$
\chi=\left|I_{0}-\int_{0}^{e V} \rho(E) T\left(z_{m}(V), V, E\right) d E\right| .
$$

Here, $I_{0}$ is the constant current setpoint and $z_{m}(V)$ is the measured tipsample separation. It should be noted that $z_{m}(V)$ will always be relative to some initial separation $z_{0}$, as is the case for all types of spectroscopy. While the value for this initial separation can not be exactly determined, it is quite possible to make a reasonable estimate.

In the ideal case, $z$ and $I$ will be exactly constant for respectively $\mathrm{I}(\mathrm{V})$ and $\mathrm{z}(\mathrm{V})$ spectroscopy measurements. However, small deviations from this constant value are always possible under experimental conditions, especially around $V=0$. In order to obtain the highest possible quality fit, it is therefore important to also measure the supposed constant parameter during experimental work. An important limitation to the proposed method comes from the fact that the integral in Equations 3.14 and 3.15 has to be evaluated from $E=0$ to $E=e V$. This means that the bias range used in the experiment should include $V=0$ or at least come as close to $V=0$ as possible. Measurements that do not fulfil this requirement can be extrapolated to include $V=0$, but this inevitably introduces inaccuracies, especially when the extrapolated bias range includes LDOS features. Because the integral is evaluated over the entire bias range, inaccuracies at any point on this range 

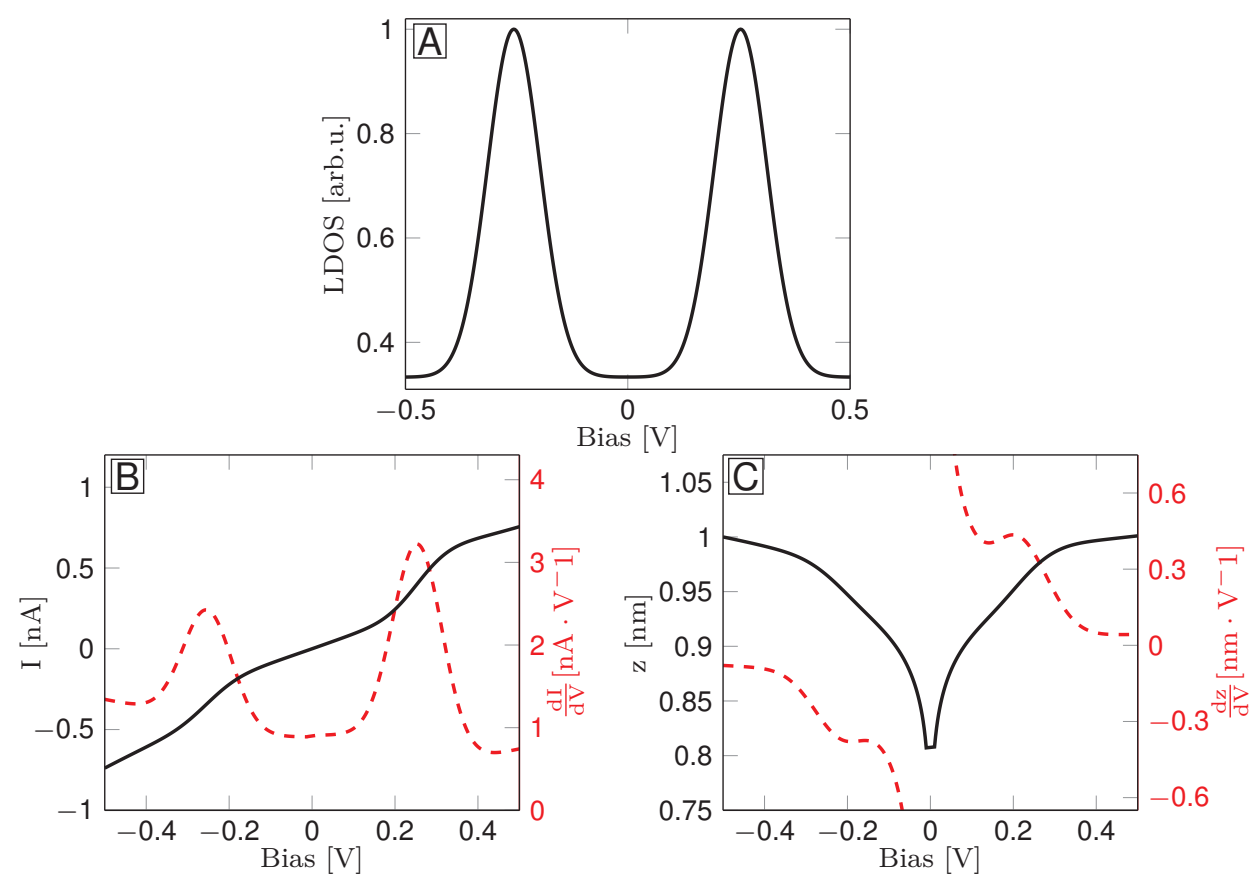

Figure 3.2: Simulated signals for a $-0.5 \mathrm{~V}$ to $0.5 \mathrm{~V}$ bias range. A) Input LDOS. B) Tunnelling current and $\frac{d I}{d V}$. C) Tip-sample separation and $\frac{d z}{d V}$.

can have a detrimental effect on the entire fit, as the fitting algorithm will attempt to compensate for any errors in order to minimise $\chi$.

\subsection{Simulations}

To test the validity of the fitting method described in the previous section, a simulated LDOS was used to generate 'measurement' data. The simulated LDOS and the resulting $\mathrm{I}(\mathrm{V})$ and $\mathrm{z}(\mathrm{V})$ data for a $-0.5 \mathrm{~V}$ to $0.5 \mathrm{~V}$ bias voltage range can be seen in Figure 3.2. The LDOS consists of a constant 'ground' level with two identical Gaussian peaks symmetrically distributed around $V=0$. The barrier height $\phi$ is equal to $5 \mathrm{eV}$. Despite the LDOS being perfectly symmetrical around $V=0$, the $\mathrm{I}(\mathrm{V})$ and $\mathrm{z}(\mathrm{V})$ signals are not, which can be seen especially well in the $\frac{d I}{d V}$ and $\frac{d z}{d V}$ signals. This behaviour is 


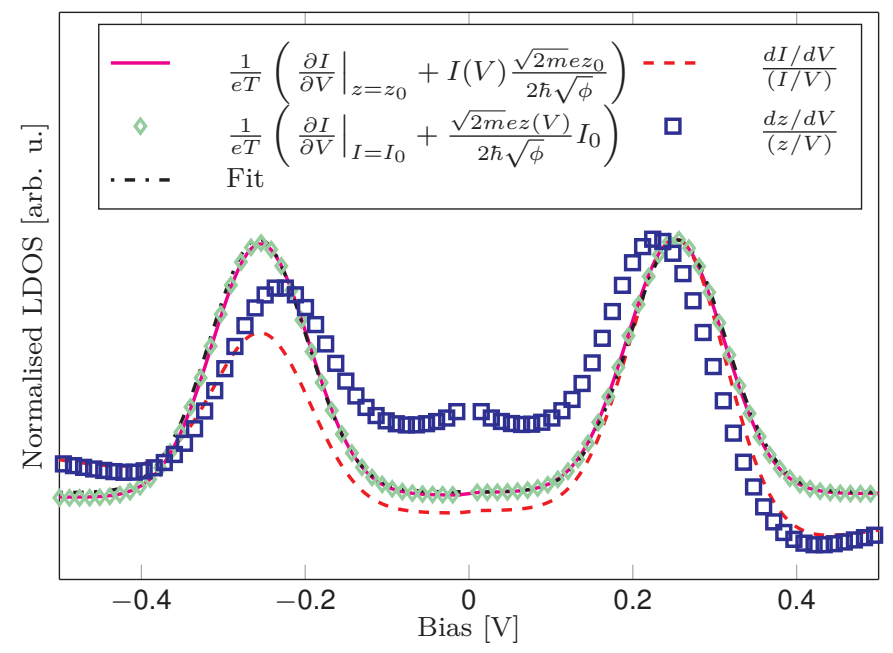

Figure 3.3: Reconstructed LDOS using five distinct methods for a $-0.5 \mathrm{~V}$ to $0.5 \mathrm{~V}$ bias range.

also observed in actual experimental data ${ }^{5,6}$ and is caused by the asymmetry in the transfer function (Equation 3.2). Clear peaks can be observed in the generated signals, with the locations of the peaks matching those of the peaks in the LDOS.

Figure 3.3 shows the LDOS as retrieved by a number of different methods for the signal shown in Figure 3.2. Using the LDOS fitting method results in the exact same LDOS as the one that was used to generate the $\mathrm{I}(\mathrm{V})$ and $\mathrm{z}(\mathrm{V})$ signals. This is not surprising, considering the exact same equations were used to generate the signals and retrieve the LDOS. The conventional (Equation 3.13), lock-in (Equation 3.11), $\frac{d z}{d V}$ and differential conductivity methods also accurately reproduce the original LDOS peak locations, although the relative height of both peaks is incorrect for the normalised differential conductivity $\left(\frac{d I / d V}{I / V}\right)$ and $\frac{d z / d V}{z / V}$ methods. Additionally, the peak positions are slightly shifted towards $V=0$ for the $\frac{d z / d V}{z / V}$ method. This shift in peak position can also be explained by considering the form of the transmission coefficient. When measuring in constant current $\mathrm{z}(\mathrm{V})$ mode, $z$ will change due to the influence of the LDOS, as well as due to the influence of the transmission coefficient as a function of the applied bias voltage. The fact that $z$ has to compensate for the bias dependent term in the transmission 

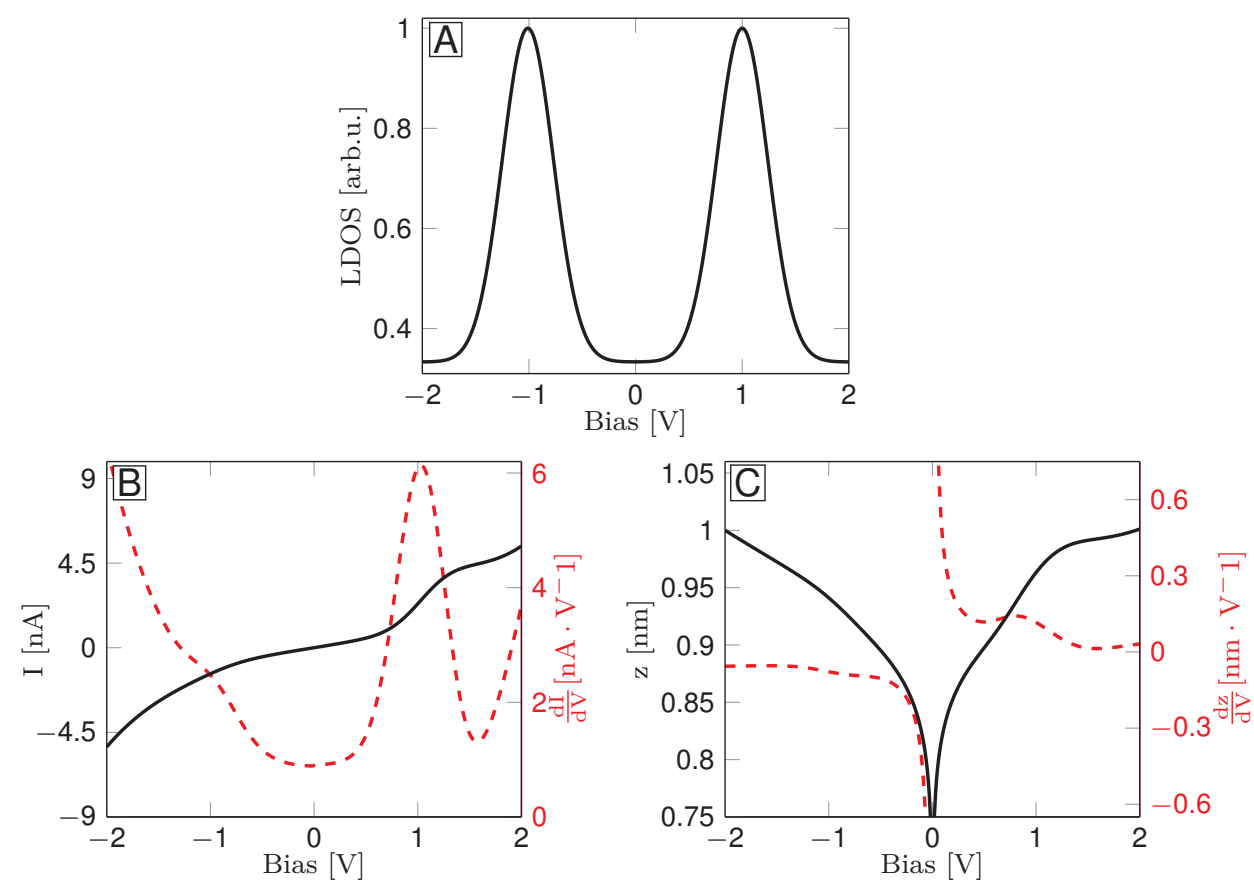

Figure 3.4: Simulated signals for a $-2 \mathrm{~V}$ to $2 \mathrm{~V}$ bias range. A) Input LDOS. B) Tunnelling current and $\frac{d I}{d V}$. C) Tip-sample separation and $\frac{d z}{d V}$.

coefficient will lead to a shift of the LDOS peaks towards $V=0$.

Figure 3.4 shows the input LDOS and resultant signals for a larger bias range of $-2 \mathrm{~V}$ to $2 \mathrm{~V}$. The shape of the input LDOS curve is the same as for the smaller bias range case, but the peaks are situated at different positions due to the larger bias range. The asymmetry of the signals is even more pronounced for this bias range, as is most clearly visible in the $\frac{d I}{d V}$ and $\frac{d z}{d V}$ signals. While the part of the signals belonging to the positive bias range exhibits a clear peak near the location of the LDOS peak, the part belonging to the negative bias range hardly shows a peak at all.

Figure 3.5 shows the reconstructed LDOS on the larger $-2 \mathrm{~V}$ to $2 \mathrm{~V}$ bias range. In this case, strong differences can be seen between the five different methods. Once again, the fitting algorithm proposed in this work perfectly reproduces the original signal. The signals reproduced by both the conventional and lock-in based methods show the same discrepancies. On the posit- 


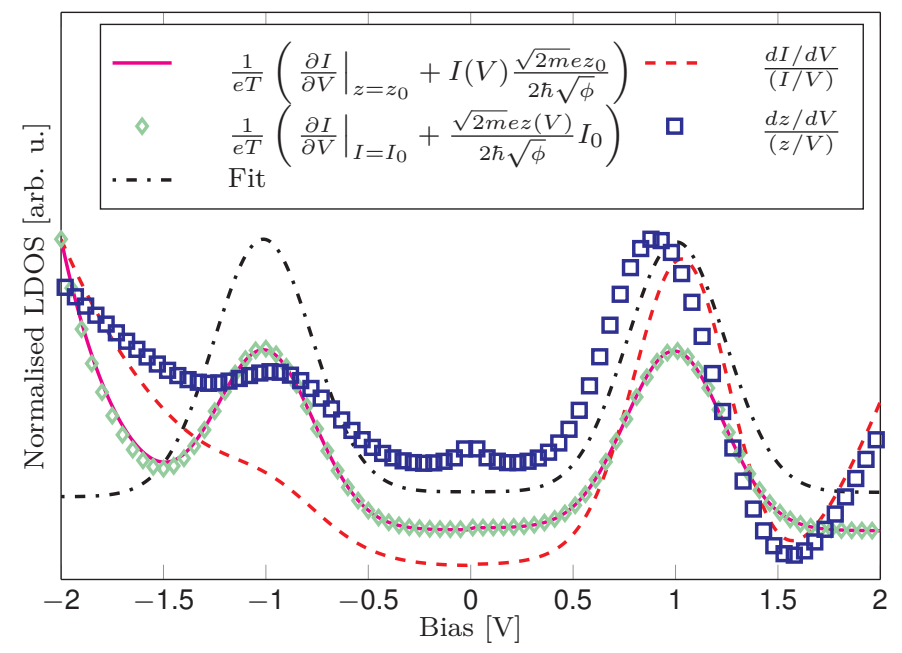

Figure 3.5: Reconstructed LDOS using five distinct methods for a $-2 \mathrm{~V}$ to 2 $\mathrm{V}$ bias range.

ive side of the spectrum, they accurately reproduce the characteristic LDOS peak as well as the plateaus around it. On the negative side of the spectrum, however, the peak appears to be superimposed onto a slope that rises with increasing negative bias. The presence of this slope can be explained by referring to Equation 3.2; as the applied sample bias becomes more negative, the square root term in the equation will increase, leading to an overall lower transmission coefficient $T$. Because the LDOS is calculated by taking the reciprocal of $T$, it will naturally start increasing for more negative bias voltages. The fitting method uses the most 'raw' forms of the applicable formulas and therefore eliminates this effect of the transmission coefficient on the reconstructed LDOS. The other methods, however, are based on formulas that have been derived through the use of several approximations to make them analytically solvable, introducing errors for larger bias ranges. The normalised differential conductivity performs quite well in the positive bias range, accurately reproducing the LDOS peak at the correct location. On the other hand, in the negative bias range the peak is hardly visible at all, as is also the case for the $\frac{d I}{d V}$ signal. This same phenomenon occurs for the $\frac{d z / d V}{z / V}$ method, in addition to the shift of the LDOS peaks towards $V=0$ which was discussed previously. 


\subsection{Conclusions}

Simulating an artificial LDOS over a varying bias range has revealed the extent to which the transmission coefficient $T$ influences the retrieved LDOS using several different methods. While the conventional methods of determining the LDOS via $\mathrm{I}(\mathrm{V})$ spectroscopy perform satisfactory at lower bias voltages, the assumptions made in the derivation of the relevant formulas introduce significant deviations once the absolute applied bias voltage exceeds $1 \mathrm{~V}$. The normalised differential conductivity, a method widely used for its relative simplicity, does not sufficiently reveal LDOS features for negative voltages beyond $-1 \mathrm{~V}$ and yields an asymmetrical LDOS even at lower bias ranges. These results indicate that caution is advised when trying to determine the LDOS for higher bias ranges, especially when measuring the negative and positive bias range simultaneously.

For measurements with a bias voltage range that includes or approaches $V=0$, the LDOS fitting method provides a viable alternative to the more conventional ways of LDOS determination. In addition to eliminating the effects of the asymmetrical transmission coefficient, the LDOS fitting method can be used with both $\mathrm{I}(\mathrm{V})$ and $\mathrm{z}(\mathrm{V})$ signals as input data, making it a versatile tool for the determination of the LDOS. Because $z(V)$ spectroscopy can be performed in closed-loop mode, this enables one to determine the LDOS of a sample using an STM system without access to a lock-in amplifier or sample-and-hold mechanism.

\section{Bibliography}

[1] G. Binnig, H. Rohrer, C. Gerber \& E. Weibel. Tunneling through a controllable vacuum gap. Appl. Phys. Lett. 40, 178-180 (1982).

[2] R. M. Feenstra. Scanning tunneling spectroscopy. Surf. Sci. 299/300, 965 - 979 (1994).

[3] A. van Houselt \& H. J. W. Zandvliet. Colloquium : Time-resolved scanning tunneling microscopy. Rev. Mod. Phys. 82, 1593-1605 (2010).

[4] B. C. Stipe, M. A. Rezaei \& W. Ho. Single-Molecule Vibrational Spectroscopy and Microscopy. Science 280, 1732-1735 (1998). 
[5] R. M. Feenstra, W. A. Thompson \& A. P. Fein. Real-space observation of $\pi$-bonded chains and surface disorder on $\mathrm{Si}(111) 2 \times 1$. Phys. Rev. Lett. 56, 608-611 (1986).

[6] J. A. Stroscio, R. M. Feenstra \& A. P. Fein. Electronic Structure of the Si(111)2x1 Surface by Scanning-Tunneling Microscopy. Phys. Rev. Lett. 57, 2579-2582 (1986).

[7] V. A. Ukraintsev. Data evaluation technique for electron-tunneling spectroscopy. Phys. Rev. B 53, 11176-11185 (1996).

[8] M. F. Crommie, C. P. Lutz \& D. M. Eigler. Imaging standing waves in a two-dimensional electron gas. Nature 363, 524-527 (1993).

[9] A. Pronschinske, D. J. Mardit \& D. B. Dougherty. Modeling the constant-current distance-voltage mode of scanning tunneling spectroscopy. Phys. Rev. B 84, 205427 (2011).

[10] J. G. Simmons. Generalized Formula for the Electric Tunnel Effect between Similar Electrodes Separated by a Thin Insulating Film. $J$. Appl. Phys. 34, 1793-1803 (1963).

[11] R. Feenstra, J. A. Stroscio \& A. Fein. Tunneling spectroscopy of the Si(111)2x1 surface. Surf. Sci. 181, 295 - 306 (1987).

[12] B. Koslowski, C. Dietrich, A. Tschetschetkin \& P. Ziemann. Evaluation of scanning tunneling spectroscopy data: Approaching a quantitative determination of the electronic density of states. Phys. Rev. B 75, 035421 (2007).

[13] M. Ziegler, N. Néel, A. Sperl, J. Kröger \& R. Berndt. Local density of states from constant-current tunneling spectra. Phys. Rev. B 80, 125402 (2009).

[14] H. Pfeifer, B. Koslowski \& P. Ziemann. Deconvolution of the density of states of tip and sample through constant-current tunneling spectroscopy. Beilstein J. Nanotechnol. 2, 607-617 (2011). 


\section{Transition voltage spectroscopy of scanning tunnelling microscopy vacuum junctions*}

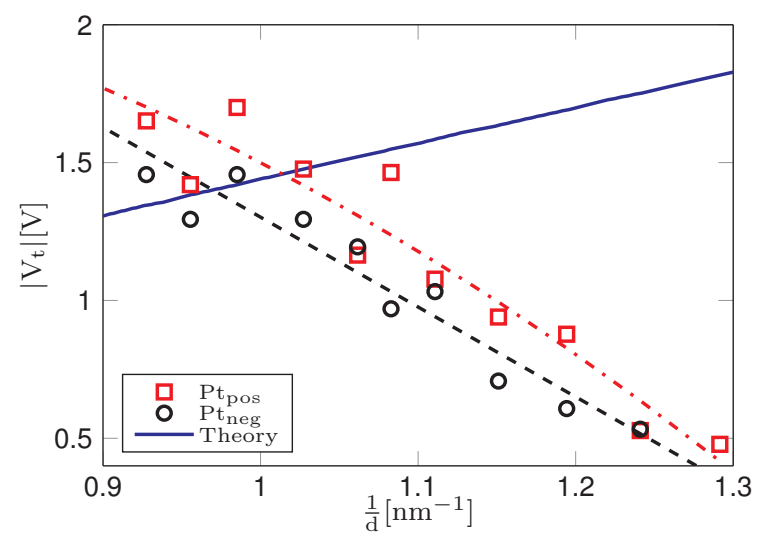

The transition voltage of a tunnelling junction can be determined by finding the minimum of a $\ln \left(\frac{I}{V^{2}}\right)$ vs. $\frac{I}{V}$ plot of said junction. In this chapter, the dependence of the transition voltage of STM vacuum junctions is studied as a function of the tunnel gap width. While standard theory predicts a linear increase of the transition voltage with increasing inverse gap width, measurements on different samples show the exact opposite effect. Including image charge effects in the analysis mitigates this discrepancy to some extent, but not enough to fully explain it.

${ }^{*}$ Published as K. Sotthewes, C. Hellenthal, A. Kumar and H.J.W. Zandvliet, RSC Adv. 4, 32438-32442 (2014) 


\subsection{Introduction}

The field of molecular electronics aims to investigate and realise elementary electronic devices relying on molecules for future applications. ${ }^{1,2}$ One of the essential parameters in charge transport through molecules is the location of the molecular energy levels with respect to the Fermi level. ${ }^{3,4} \mathrm{~A}$ wellestablished method to determine the electronic structure of an electrodemolecule-electrode junction is a form of scanning tunnelling spectroscopy known as current-voltage or I(V) spectroscopy. An increase in the measured current $I$ is observed when the Fermi level of one of the contacts lines up with a molecular energy level due to the applied bias voltage $V$. The molecular levels that can be accessed by scanning tunnelling spectroscopy typically lie in the range of several eVs around the Fermi level. Since the gap spacing in scanning tunnelling microscopy is typically below $1 \mathrm{~nm}$, the electric field strength can easily exceed $1 \times 10^{9} \mathrm{~V} \mathrm{~m}^{-1}$.

Beebe et al. ${ }^{5}$ introduced transition voltage spectroscopy (TVS) as an alternative method to determine the tunnelling barrier height $\phi$, which is the energy difference between the LUMO (lowest unoccupied molecular orbital) position and the Fermi level. For hole tunnelling, the barrier height is given by the energy difference between the HOMO (highest occupied molecular orbital) and the Fermi level. Beebe et al. proposed that the transition voltage $V_{t}$, which is the minimum in a Fowler-Nordheim $(\mathrm{F}-\mathrm{N})$ plot, i.e. a plot of $\ln \left(\frac{I}{V^{2}}\right)$ versus $\frac{I}{V}$, provides direct information on the tunnelling barrier height. Since the transition voltage is substantially smaller than the effective barrier height, this method allows one to study molecular levels at much smaller electric fields.

This interpretation of TVS was based on a picture of molecular junctions as tunnel barriers obeying the Simmons model for charge transport. ${ }^{6}$ In this model, $V_{t}$ indicates the point where the shape of the energy barrier, tilted by the applied bias voltage, changes from trapezoidal to triangular. The promise of determining the barrier height with such ease has led to a number of experimental ${ }^{4,7-12}$ and theoretical studies ${ }^{13-17}$ on TVS in molecular junctions. Later it was realised that, mathematically, the transition voltage is in fact a characteristic of pronounced nonlinear transport. More precisely, it defines the point where the differential conductance is twice the pseudo-ohmic conductance $\left(\frac{d I}{d V}=2 \frac{I}{V}\right) \cdot{ }^{18-22}$

Calculations of the tunnelling current within the Simmons model chal- 
lenged the validity of the barrier description for molecular junctions, ${ }^{19}$ leading to claims that $V_{t}$ is not only related to the barrier height but is also sensitive to other factors, such as the asymmetry of the junction and the molecular length (or tunnelling distance). ${ }^{19,23}$ Based on these calculations it was suggested that TVS could be used as a tool to distinguish molecular junctions from vacuum junctions.

To check this assumption, Trouwborst et al. ${ }^{24}$ investigated the distance dependence of the transition voltage of Au-vacuum-Au mechanically controlled break junctions (MBJ). They observed that, contrary to the initial predictions, ${ }^{19}$ the experimental distance dependence of $V_{t}$ in vacuum junctions is less pronounced than observed in molecular junctions. ${ }^{4}$ This weaker dependence was attributed to the image charge potential which lowers the barrier height for smaller vacuum gap widths. However, a substantial difference remained between the experimental data and available theoretical predictions, even when taking this effect into account. For small gap widths, the effect of an image charge potential is smaller for an MBJ than for an STM junction because the MBJ vacuum junctions consist of two atomically sharp electrodes, ${ }^{25}$ whereas an STM junction is composed of a planar and an atomically sharp electrode. Given the fact that image potential effects are expected to be more pronounced in STM junctions it is worthwhile to perform TVS in an STM junction.

As such, this chapter documents the results obtained from investigating the dependence of the transition voltage as a function of gap width in a tungstenvacuum-sample junction. Tungsten (W) was used as the tip material and two different types of samples were used: flame-annealed gold (Au) (111) and granular platinum (Pt). In contrast to theoretical models, which predict a linear increase of the transition voltage with increasing inverse gap, a linear decrease of the transition voltage was observed. In addition, the transition voltage, corresponding to the minima in the F-N-plot, was found to change from $1.8 \mathrm{~V}$ to $0.5 \mathrm{~V}$ as the vacuum gap width is reduced by $0.4 \mathrm{~nm}$. Such a dramatic variation of the transition voltage cannot be explained by the incorporation of an image charge potential in the popular and well-established Simmons model $^{6}$ as predicted by Huisman et al. ${ }^{19}$ 


\subsection{Experimental}

Experiments were carried out in an ultra-high vacuum (UHV) Omicron roomtemperature scanning tunnelling microscope. The Pt substrates were prepared by physical vapour deposition of $200 \mathrm{~nm}$ Pt on a Si substrate resulting in a granular structure. Au substrates $\left(11 \times 11 \mathrm{~mm}^{2}, 250 \mathrm{~nm} \mathrm{Au}\right.$ on $2 \mathrm{~nm}$ $\mathrm{Cr}$ on borosilicate glass) for STM measurements were purchased from Arrandee (Werther, Germany). $\mathrm{Au}(111)$ samples were obtained by annealing the substrates in a high purity $\mathrm{H}_{2}$ flame for 5 min. The measurements were performed using a $\mathrm{W}$ tip prepared by electrochemical etching. In total, approximately $10000 \mathrm{I}(\mathrm{V})$ curves were recorded on each substrate. The I(V) measurements were recorded with the tip at a predefined gap width. The feedback loop was switched off and a voltage ramp $(2.5 \mathrm{~V}$ to $-2.5 \mathrm{~V})$ was applied with a typical voltage step size of $15 \mathrm{mV}$. In order to remove the offset of the IV-converter, the current at zero bias was set to zero for each $\mathrm{I}(\mathrm{V})$ trace. Distance dependent $\mathrm{I}(\mathrm{V})$ measurements were realised by changing the setpoint current at a constant sample bias voltage. The sample bias voltage was kept at the same value as the start voltage of the $\mathrm{I}(\mathrm{V})$ measurement to avoid any capacitive induced artefacts. Current-distance I(z) spectroscopy was performed to determine the relative separation between the tip and substrate. A fraction $(\sim 5 \%)$ of the $\mathrm{I}(\mathrm{V})$ curves were excluded from the analysis because of the presence of current peaks induced by instabilities at larger tunnelling currents, i.e. smaller substrate-tip separations.

\subsection{Results and Discussion}

Huisman et al. ${ }^{19}$ derived the following expression for $V_{t}$ by reformulating the Stratton formula, ${ }^{26}$

$$
V_{t}=\frac{2 \hbar}{e \sqrt{m}} \frac{\sqrt{2 \phi}}{d}
$$

where $e$ is the electronic charge, $m$ the electronic mass, $\phi$ is the tunnelling barrier height and $d$ the tunnel barrier width in a simple square barrier model. They also showed that the difference between the Stratton and Simmons model is negligible, despite the fact that the Stratton approach is only an approximation. In the Simmons model, the tunnelling current is, for small 


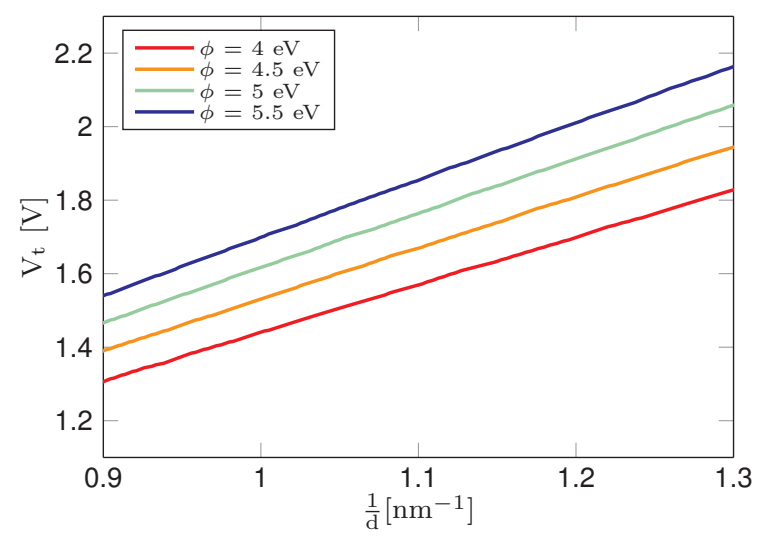

Figure 4.1: Theoretically predicted $V_{t}$ versus $\frac{1}{d}$ graph for various barrier heights.

voltages, given by,

$$
I \propto \frac{V}{d} \sqrt{\left(\phi-\frac{e V}{2}\right)} e^{-2 \frac{\sqrt{2 m}}{\hbar} d \sqrt{\phi-\frac{e V}{2}}} .
$$

The only 'free' variable parameter in this equation is the tunnelling barrier height $\phi$. Figure 4.1 shows a number of $V_{t}$ versus $\frac{1}{d}$ plots as obtained from the Simmons model. As expected, a variation of $\phi$ does not have a large effect on the $V_{t}$ versus $\frac{1}{d}$ curves. Figure 4.2 shows an STM topography image of the Pt sample, as well as a set of $\mathrm{I}(\mathrm{V})$ measurements taken at a bias range from $-2.5 \mathrm{~V}$ to $2.5 \mathrm{~V}$. The tip-substrate distance was varied by changing the setpoint current from $0.02 \mathrm{nA}$ to $40 \mathrm{nA}$ at a constant bias voltage of $2.5 \mathrm{~V}$. Increasing the current setpoint at a fixed bias voltage causes the tip-substrate distance to decrease. The variation of the tip-sample distance as a function of the current setpoint was determined through the use of $\mathrm{I}(\mathrm{z})$ measurements. These measurements indicate that changing the current setpoint from $0.02 \mathrm{nA}$ to $40 \mathrm{nA}$ results in a decrease in tip-substrate distance of $0.4 \mathrm{~nm}$. The I(V) measurements shown in Figure 4.2B exhibit metal-vacuummetal junction behaviour, judging from the non-zero differential conductance values at zero bias. At lower bias values, the slope of the $\mathrm{I}(\mathrm{V})$ curves behaves in a linear fashion, whereas for higher bias values the slope exhibits a rather steep increase.

This trend can be further emphasised by plotting the $\mathrm{I}(\mathrm{V})$ curves in a 

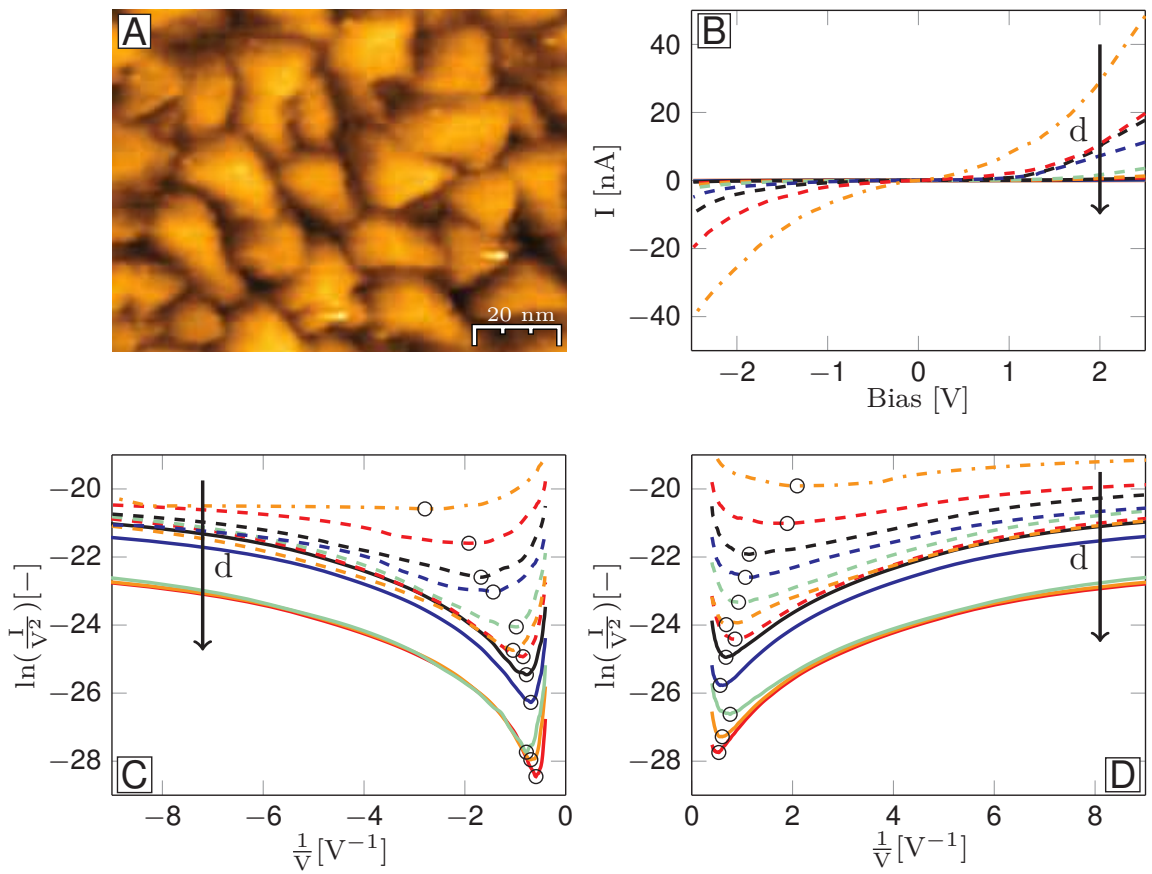

Figure 4.2: A) STM image of a polycrystalline Pt surface. B) I(V) measurements recorded on the $\mathrm{Pt}$ surface for varying setpoint currents. C) and D) Fowler-Nordheim (F-N) plot extracted from the I(V) measurements shown in Figure B. Minima are indicated by a circle. The arrow points in the direction of increasing vacuum gap width, $d$.

Fowler-Nordheim representation, as depicted in Figure 4.2C and 4.2D. The black circles indicate the minima of the F-N I $(\mathrm{V})$ curves, which represent the transition voltage $V_{t}$. From Figure $4.2 \mathrm{C}$ it becomes immediately apparent that the transition voltage changes as a function of tip-sample separation. $V_{t}$ increases with increasing gap width $d$. The value of $V_{t}$ varies from $0.5 \mathrm{~V}$ at gap separations of approximately $0.8 \mathrm{~nm}$ to almost $2.0 \mathrm{~V}$ at separations of $1.2 \mathrm{~nm}$. Furthermore, the transition appears to become sharper as the tip-sample separation increases, changing from a rather broad minimum at $0.8 \mathrm{~nm}$ to a sharp and well-defined minimum at separations of $1.2 \mathrm{~nm}$. No plateaus or double minima were observed in the F-N plots.

Figure 4.3 shows the same type of measurements for a $\mathrm{Au}(111)$ substrate. 

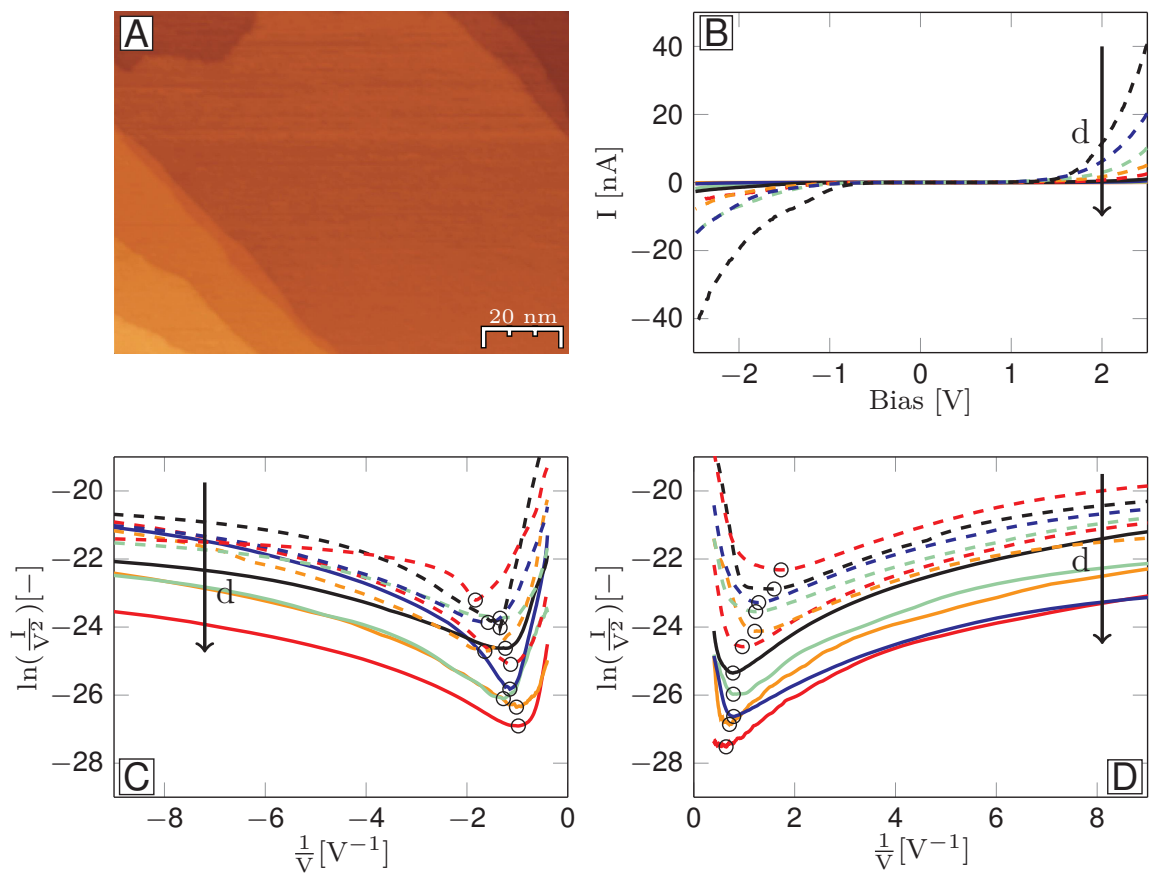

Figure 4.3: A) STM image of $\mathrm{Au}(111)$. B) I(V) measurements recorded on $\mathrm{Au}(111)$ for varying setpoint currents. C) and D) FowlerNordheim (F-N) plot extracted from the I(V) measurements shown in Figure B. Minima are indicated by a circle. The arrow points in the direction of increasing vacuum gap width.

From the STM image, it is clear that the Au surface consists of large (111) oriented terraces separated by atomic steps. The $\mathrm{I}(\mathrm{V})$ curves (Figure $4.3 \mathrm{~B}$ ) and F-N curves (Figure 4.3C and 4.3D) show the same general trend as those recorded on the $\mathrm{Pt}$ sample: $V_{t}$ shifts to higher values and the transition becomes sharper as the tip-sample separation increases. The transitions, especially for small $d$, do appear to be a bit sharper than those observed for the Pt substrate.

In order to compare the obtained results with the Stratton ${ }^{26}$ and Simmons ${ }^{6}$ models and previously conducted experiments on molecular break junctions, ${ }^{24}$ the minima of the F-N plots (i.e. $V_{t}$ ) were plotted versus $\frac{1}{d}$. Figure 4.4 shows the results of the measurements performed on the Pt (Figure $4.4 \mathrm{~A}$ ) and $\mathrm{Au}(111)$ (Figure 4.4B) substrates. The absolute values of $V_{t}$ for 

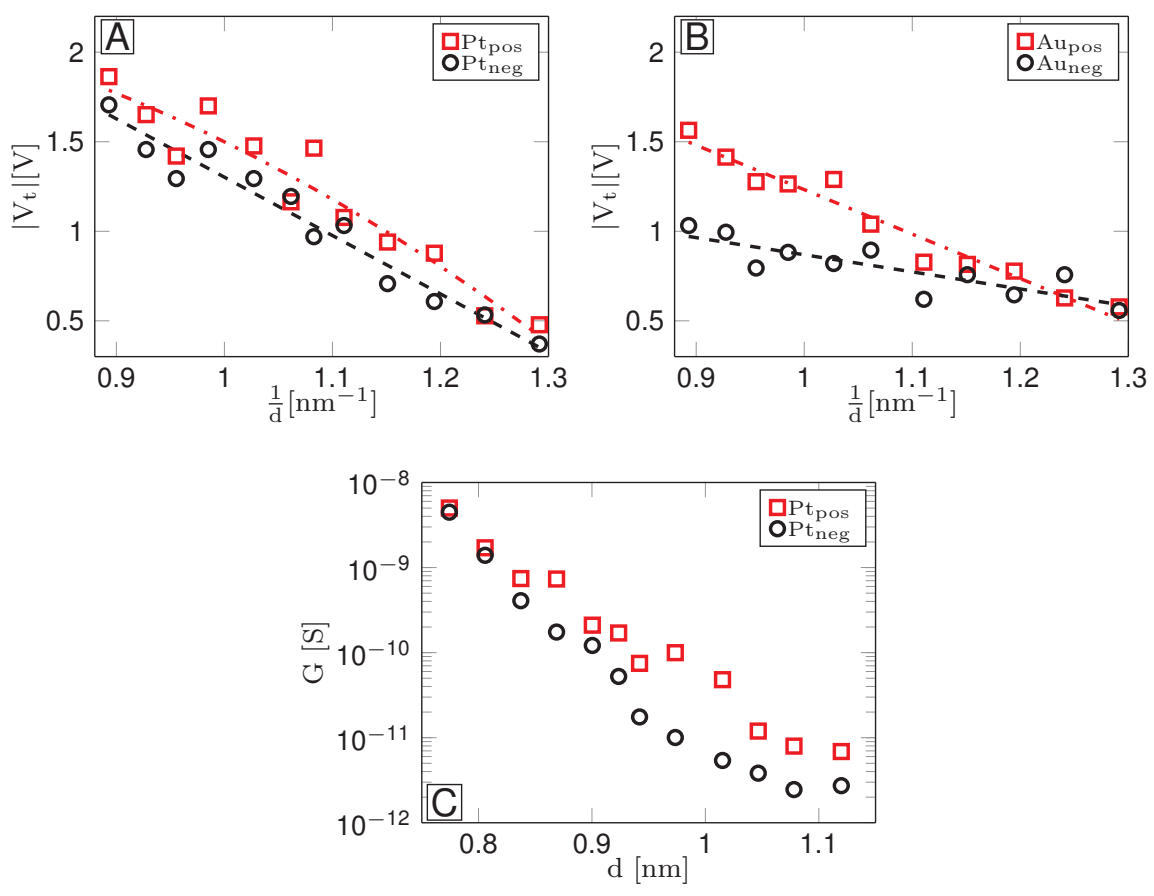

Figure 4.4: A) Absolute value of the transition voltage for Pt plotted versus $\frac{1}{d}$. B) Absolute value of the transition voltage for Au plotted versus $\frac{1}{d}$. C) Semi-log plot of the conductance $G$ at the transition voltage $\left(G=\frac{I_{t}}{V_{t}}\right)$ versus $d$. At $d=1 \mathrm{~nm}$ a transition from an exponential dependence to a non-exponential dependence is observed.

both the positive and negative bias ranges are plotted as a function of $\frac{1}{d}$. This plot clearly shows that $V_{t}$ varies between $1.8 \mathrm{~V}$ and $0.5 \mathrm{~V}$ in the range of $0.9 \mathrm{~nm}^{-1}$ to $1.3 \mathrm{~nm}^{-1}$. The most striking feature of Figure 4.4 is the slope of the curves: the theory predicts a linear increase of $V_{t}$ with increasing $\frac{1}{d}$, whereas the experiments reveal a linear decrease of $V_{t}$ with increasing $\frac{1}{d}$. Additionally, the dependence of $V_{t}$ on $\frac{1}{d}$ is far stronger in the presented STS measurements $\left(1.5 \mathrm{~V}\right.$ in the range of $0.9 \mathrm{~nm}^{-1}$ to $\left.1.3 \mathrm{~nm}^{-1}\right)$ than found by Trouwborst et al. ${ }^{24}$ in their MBJ experiments $\left(0.5 \mathrm{~V}\right.$ over $\left.0.6 \mathrm{~nm}^{-1}\right)$. This observation calls into question previous claims that the magnitude of the absolute values of $V_{t}$ can be used to distinguish vacuum junctions from molecular junctions. 
The values of $V_{t}$ for the Au sample at positive biases are slightly lower than those for Pt, which can be explained by the fact that Pt has a higher work function than Au. Interestingly, there is a substantial difference in the slope of the transition voltage of $\mathrm{Au}(111)$ versus $\frac{1}{d}$ for positive and negative sample biases. The decrease of the transition voltage of $\mathrm{Au}(111)$ at negative sample biases can be ascribed to the presence of a surface state located at $0.5 \mathrm{eV}$ below the Fermi level of $\mathrm{Au}(111) .{ }^{27}$

Another intriguing experimental observation is the distance dependence of the conductance at the transition point, i.e. $G_{t}\left(=\frac{I_{t}}{V_{t}}\right)$, as a function of $d$ (see Figure 4.4C). For small $d$ values an exponential decay is found, but at gap widths larger than $1 \mathrm{~nm}$, a crossover to a much weaker dependence is found. For the $\mathrm{Au}(111)$ samples, only an exponential decay of the conductance is observed without any indication for the presence of a crossover.

In an attempt to explain the large discrepancy between the predicted and measured behaviour of $V_{t}$ as a function of $\frac{1}{d}$, the effect of an image charge potential can be considered, as has been suggested by Huisman et al. ${ }^{19}$ and Trouwborst et al. ${ }^{24}$ The existence of image charges ${ }^{6}$ can have an effect on the tunnelling barrier height and width, as has been pointed out in previous studies. ${ }^{19,24}$ To incorporate the effect of an image charge in the Simmons model, an extra term has to be added to the effective barrier height. The mean value of the potential barrier height, $\bar{\phi}$, is then given by:

$$
\bar{\phi}=\phi_{0}-\frac{e V\left(d_{2}-d_{1}\right)}{2 d}-1.15 \zeta \frac{e^{2} \ln (2) d}{16 \phi \epsilon_{0}\left(d_{2}-d_{1}\right)} \ln \left[\frac{d_{2}\left(d-d_{1}\right)}{d_{1}\left(d-d_{2}\right)}\right] .
$$

When Equation 4.3 is substituted into Equation 4.2, the following expression for the current is obtained

$$
I \propto \frac{V}{d} \sqrt{\bar{\phi}} e^{-2 \frac{\sqrt{2 m}}{\hbar}} d \sqrt{\bar{\phi}}
$$

Here, $d_{1}$ is the distance between the potential barrier at the Fermi level of the tip and the vacuum, and $d_{2}$ is the distance from the vacuum to the potential barrier of the sample. Thus, the barrier width at the Fermi level decreases from $d$ to $d_{2}-d_{1}$. $\zeta$ varies between 0 for a system consisting of two atomically sharp tips (i.e. a break junction) and 1 for a system consisting of two parallel plates. For all non-zero values of $\zeta$, the image charges will lower the effective barrier, and thus cause the value of $V_{t}$ to drop as well. Because the impact of the image charges is also dependent on the tip-substrate separation, a nonzero value for $\zeta$ will also introduce a curvature in the $V_{t}$ versus $\frac{1}{d}$ plot for 

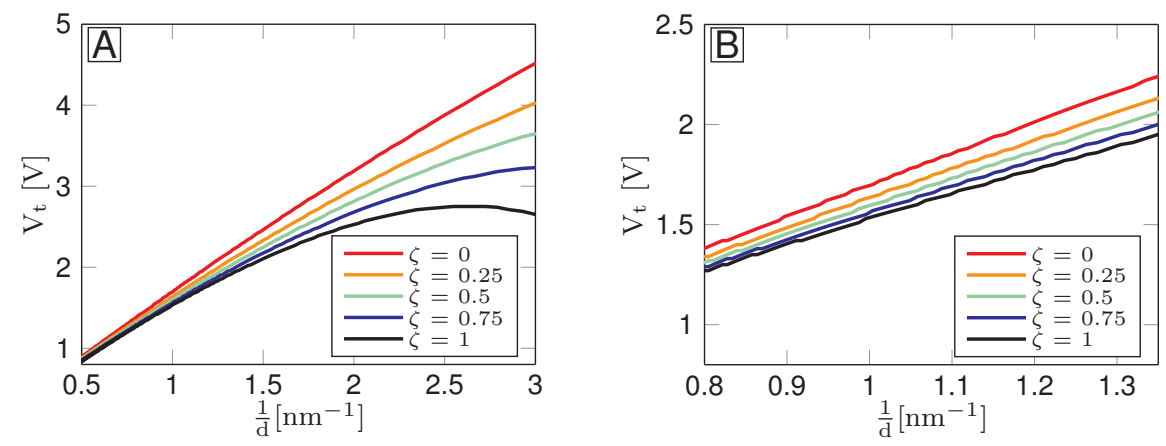

Figure 4.5: The effect of an image charge potential $(\zeta=0.25,0.50,0.75$ and 1) A) for an extended $\frac{1}{d}$ range and B) for an $\frac{1}{d}$ range typical to the performed STS experiments.

sufficiently small values of $d$. Figure 4.5A shows that for high values of $\zeta$, the slope of the $V_{t}$ versus $\frac{1}{d}$ plot will eventually change sign. However, this only happens for values of $\frac{1}{d}$ that are substantially larger than typical STS gap widths. Figure $4.5 \mathrm{~B}$ shows the effect of different $\zeta$ values for the $\frac{1}{d}$ ranges that were typically encountered during experimental STS measurements. At these gap widths, $\zeta$ has only very little effect on the transition voltage aside from a small offset. Therefore, image charges cannot explain the negative slopes found in the experimental $V_{t}$ versus $\frac{1}{d}$ plots. As such, it appears that the current Simmons model does not capture the quantum mechanical tunnelling process of a STM junction perfectly. At this stage, it is unclear how the Simmons model should be modified or extended to improve the agreement between experiment and theory.

\subsection{Conclusions}

The dependence of the transition voltage (minimum in a Fowler-Nordheim plot) on the vacuum gap width in ultra-high vacuum scanning tunnelling microscopy junctions has been determined. In contrast to theoretical predictions, the transition voltage does not increase, but rather decreases with increasing inverse gap width. Including the effects of image charges in the standard Simmons model is insufficient to account for this discrepancy, indicating the need for further experimental and theoretical study to determine the exact cause of this behaviour. 


\section{Bibliography}

[1] S. J. van der Molen \& P. Liljeroth. Charge transport through molecular switches. J. Phys.: Condens. Matter 22, 133001 (2010).

[2] K. Sotthewes, V. Geskin, R. Heimbuch, A. Kumar \& H. J. W. Zandvliet. Research Update: Molecular electronics: The single-molecule switch and transistor. APL Materials 2, 01070101 - 01070111 (2014).

[3] S. H. Choi, B. S. Kim \& C. D. Frisbie. Electrical Resistance of Long Conjugated Molecular Wires. Science 320, 1482-1486 (2008).

[4] J. M. Beebe, B. Kim, C. D. Frisbie \& J. G. Kushmerick. Measuring Relative Barrier Heights in Molecular Electronic Junctions with Transition Voltage Spectroscopy. ACS Nano 2, 827-832 (2008).

[5] J. M. Beebe, B. S. Kim, J. W. Gadzuk, C. D. Frisbie \& J. G. Kushmerick. Transition from Direct Tunneling to Field Emission in Metal-MoleculeMetal Junctions. Phys. Rev. Lett. 97, 026801 (2006).

[6] J. G. Simmons. Generalized Formula for the Electric Tunnel Effect between Similar Electrodes Separated by a Thin Insulating Film. $J$. Appl. Phys. 34, 1793-1803 (1963).

[7] L. H. Yu, N. Gergel-Hackett, C. D. Zangmeister, C. A. Hacker, C. A. Richter \& J. G. Kushmerick. Molecule-induced interface states dominate charge transport in Si-alkyl-metal junctions. J. Phys.: Condens. Matter 20, 374114 (2008).

[8] N. Bennett, G. Xu, L. J. Esdaile, H. L. Anderson, J. E. Macdonald \& M. Elliott. Transition Voltage Spectroscopy of Porphyrin Molecular Wires. Small 6, 2604-2611 (2010).

[9] M. C. Lennartz, N. Atodiresei, V. Caciuc \& S. Karthauser. Identifying Molecular Orbital Energies by Distance-Dependent Transition Voltage Spectroscopy. J. Phys. Chem. C 115, 15025-15030 (2011).

[10] G. Wang, Y. Kim, S. I. Na, Y. H. Kahng, J. Ku, S. Park, Y. H. Jang, D. Y. Kim \& T. Lee. Investigation of the Transition Voltage Spectra of Molecular Junctions Considering Frontier Molecular Orbitals and 
the Asymmetric Coupling Effect. J. Phys. Chem. C 115, 17979-17985 (2011).

[11] S. Guo, J. Hihath, I. Díez-Pérez \& N. Tao. Measurement and Statistical Analysis of Single-Molecule Current-Voltage Characteristics, Transition Voltage Spectroscopy, and Tunneling Barrier Height. J. Am. Chem. Soc. 133, 19189-19197 (2011).

[12] G. Ricœur, S. Lenfant, D. Guérin \& D. Vuillaume. Molecule/Electrode Interface Energetics in Molecular Junction: A Transition Voltage Spectroscopy Study. J. Phys. Chem. C 116, 20722-20730 (2012).

[13] T. Markussen, J. Chen \& K. S. Thygesen. Improving transition voltage spectroscopy of molecular junctions. Phys. Rev. B 83, 155407 (2011).

[14] K. Wu, M. Bai, S. Sanvito \& S. Hou. Origin of the transition voltage in gold-vacuum-gold atomic junctions. Nanotechnology 24, 025203 (2013).

[15] J. Chen, T. Markussen \& K. S. Thygesen. Quantifying transition voltage spectroscopy of molecular junctions: Ab initio calculations. Phys. Rev. B 82, 121412 (2010).

[16] I. Baldea. Transition voltage spectroscopy: Artefacts of the Simmons approach. J. Phys. Chem. Solids 73, $1151-1153$ (2012).

[17] K. Wu, M. Bai, S. Sanvito \& S. Hou. Quantitative interpretation of the transition voltages in gold-poly(phenylene) thiol-gold molecular junctions. J. Chem. Phys. 139, 1947031 - 1947036 (2013).

[18] I. Baldea. Interpretation of Stochastic Events in Single-Molecule Measurements of Conductance and Transition Voltage Spectroscopy. J. Am. Chem. Soc. 134, 7958-7962 (2012).

[19] E. H. Huisman, C. M. Guédon, B. J. van Wees \& S. J. van der Molen. Interpretation of Transition Voltage Spectroscopy. Nano Lett. 9, 39093913 (2009).

[20] A. Vilan, D. Cahen \& E. Kraisler. Rethinking Transition Voltage Spectroscopy within a Generic Taylor Expansion View. ACS Nano 7, 695-706 (2013). 
[21] M. Araidai \& M. Tsukada. Theoretical calculations of electron transport in molecular junctions: Inflection behavior in Fowler-Nordheim plot and its origin. Phys. Rev. B 81, 235114 (2010).

[22] I. Baldea. Effects of stochastic fluctuations at molecule-electrode contacts in transition voltage spectroscopy. Chem. Phys. 400, 65-71 (2012).

[23] F. Mirjani, J. M. Thijssen \& S. J. van der Molen. Advantages and limitations of transition voltage spectroscopy: A theoretical analysis. Phys. Rev. B 84, 115402 (2011).

[24] M. L. Trouwborst, C. A. Martin, R. H. M. Smit, C. M. Guédon, T. A. Baart, S. J. van der Molen \& J. M. van Ruitenbeek. Transition Voltage Spectroscopy and the Nature of Vacuum Tunneling. Nano Lett. 11, 614-617 (2011).

[25] I. Baldea \& H. Köppel. Transition voltage spectroscopy in vacuum break junction: The standard tunneling barrier model and beyond. Phys. Status Solidi B 249, 1791-1804 (2012).

[26] R. Stratton. Volt-current characteristics for tunneling through insulating films. J. Phys. Chem. Solids 23, $1177-1190$ (1962).

[27] W. Chen, V. Madhavan, T. Jamneala \& M. F. Crommie. Scanning Tunneling Microscopy Observation of an Electronic Superlattice at the Surface of Clean Gold. Phys. Rev. Lett. 80, 1469-1472 (1998). 



\section{Determining the local tunnelling barrier in open- and closed-loop scanning tunnelling microscopy*}

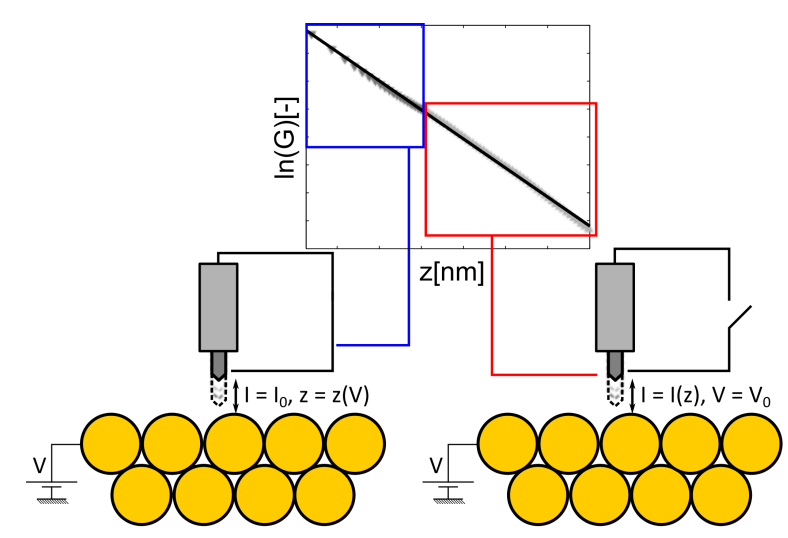

In this chapter, the validity of using closed-loop $\mathrm{z}(\mathrm{V})$ conductance scanning tunnelling spectroscopy (STS) measurements for the determination of the effective tunnelling barrier is demonstrated by comparing the results obtained via this method to those gathered from more conventional open-loop I(z) measurements. Through the development of a numerical model, the individual contributions to the effective tunnelling barrier present in these experiments, such as the work function and the presence of an image charge, are determined quantitatively.

* Manuscript accepted for publication in Beilstein Journal of Nanotechnology as part of the "Molecular machines and devices" thematic series. 


\subsection{Introduction}

Although the Scanning Tunnelling Microscope (STM) has been used for the topographical imaging of conductive samples since the early $1980 \mathrm{~s},{ }^{1}$ recent times have seen an increasing interest in the (semi-)quantitative analysis possibilities offered by Scanning Tunnelling Spectroscopy (STS). STS measurements are typically performed in a $\mathrm{X}(\mathrm{Y})$ format, where variable $Y$ is actively driven and the response of variable $X$ is measured, with all other system variables being kept constant. Numerous types of STS can and have been performed on a wide variety of samples, with each different type of measurement yielding information on distinct properties of the probed sample. ${ }^{2}$

The local density of states of a sample (LDOS) provides insight into its electronic and chemical properties. By making a spatial map of the LDOS, standing wave patterns and local electron distributions can be visualised, enabling further understanding of the exact local quantum behaviour of features on the surface. ${ }^{3,4}$ LDOS information is typically extracted via open-loop $\mathrm{I}(\mathrm{V})$ measurements, although recent studies have reported on the possibility of obtaining LDOS information by using closed-loop $\mathrm{z}(\mathrm{V})$ measurements. ${ }^{5-8}$

Another field of interest is the determination of the work function of materials, either through the use of STS or mechanical break junction (MBJ) measurements. In the case of STS measurements, perhaps the most simple method of determining the work function is performing $\mathrm{I}(\mathrm{z})$ spectroscopy and plotting the natural logarithm of the measured tunnelling conductance $G$ as function of tip-sample distance. The slope of the obtained line is equal to the inverse decay length $\kappa$ which, for low bias voltages, is proportional to the square root of the work function. Several papers have also been written on the validity of applying this same method to $z(V)$ spectroscopy measurements, ${ }^{9-11}$ although no direct comparison between $\mathrm{z}(\mathrm{V})$ and $\mathrm{I}(\mathrm{z})$ measurements was performed. Another method relies on the observation of socalled Gundlach oscillations. ${ }^{12,13}$ These oscillations can be observed in $\mathrm{I}(\mathrm{V})$ and $\mathrm{z}(\mathrm{V})$ measurements, but require the use of bias voltages that exceed the work function of the probed sample, often necessitating bias voltages in excess of $4 \mathrm{~V}$. In order to get around this restriction, recent studies have focussed on the application of Transition Voltage Spectroscopy (TVS). ${ }^{14-16}$ By determining the bias voltage at which traditional tunnelling is replaced by Fowler-Nordheim transport as a function of tip-sample distance, the work function can be determined at relatively low bias voltages of about $2 \mathrm{~V}$. 
A potential source of error when determining the work function in a vacuum system is the presence of image charges. ${ }^{17,18}$ These image charges are induced by tunnelling electrons and have an attractive interaction with them, lowering, narrowing and rounding off the tunnelling barrier, leading to a lower measured effective barrier height. If one simply assumes that the effective barrier height is equal to the work function, the presence of image charges will lead to values for $\phi_{0}$ that are significantly lower than one would expect.

In this chapter, the effective tunnelling barrier height is determined through the use of conductance measurements performed in $\mathrm{I}(\mathrm{z})$ and $\mathrm{z}(\mathrm{V})$ spectroscopy mode. The equivalence of both methods is demonstrated by comparing the obtained results and plotting them in a single graph. Additionally, an alternative numerical method of determining the work function of a sample via $\mathrm{I}(\mathrm{z})$ and $\mathrm{z}(\mathrm{V})$ spectroscopy is presented. Using the proposed method enables one to decouple the contributions of the work function $\phi_{0}$ and the image charge to the effective potential barrier $\phi$. Furthermore, there is no need for the elevated bias voltages associated with Gundlach oscillations and TVS measurements. Finally, the fact that the method can be applied by using $\mathrm{z}(\mathrm{V})$ spectroscopy means that it can also be used with STM devices that can only measure in closed-loop mode.

\subsection{Model}

An often used expression for the tunnelling current was introduced by Simmons in $1963^{17}$ and is given as

$$
I=\frac{\rho V \sqrt{\phi}}{z} e^{-\alpha \sqrt{\phi} z}
$$

Here $I$ is the tunnelling current, $\rho=\rho(V)$ is the energy dependent combined density of states of the tip and the sample, $V$ is the applied tip-sample bias voltage, $z$ is the tip-sample distance, $\phi$ is the tunnelling barrier and $\alpha=2 \frac{\sqrt{2 m}}{\hbar}$, with $m$ the rest mass of the electron. The product $\alpha \sqrt{\phi}$ is sometimes referred to as the inverse decay length

$$
\kappa=\alpha \sqrt{\phi},
$$

and provides a measure of the change in tunnelling current for a given decrease or increase in the tip-sample separation. 
Assuming a symmetrical, rectangular barrier, the term $\sqrt{\phi}$ is simply equal to the square root of the combined vacuum work function of the tip-sample system, i.e.

$$
\phi=\phi_{0} \approx \frac{\phi_{\mathrm{tip}}+\phi_{\mathrm{sample}}}{2}
$$

However, applying a bias voltage between the tip and sample causes the barrier to lower in an asymmetrical fashion:

$$
\phi(V)=\phi_{0}-\frac{e V}{2} .
$$

Any charge travelling between the tip and the sample will induce an image charge of equal magnitude but opposite polarity. In addition to lowering the barrier, the presence of an image charge effect will also narrow it. This effect can be included in the Simmons model by replacing the tip-sample separation $z$ with the effective barrier width $s$ :

$$
I=\frac{\rho V \sqrt{\phi}}{s} e^{-\alpha \sqrt{\phi} s}
$$

where the effective barrier width $s$ is given by: ${ }^{17,19}$

$$
s=z \sqrt{1-\frac{4 a}{z}} .
$$

Here, $a$ is given by

$$
a=\zeta \frac{1.15 e^{2} \ln (2)}{16 \pi \epsilon_{0} \phi_{0}},
$$

with $\epsilon_{0}$ the electric permittivity of the vacuum and $\zeta$ a constant between 0 (two point charges) or 1 (two infinite parallel plates) determining the strength of the image charge effect.

The lowering effect of the image charge can be included in the effective barrier expression as follows: ${ }^{17}$

$$
\phi(V, z)=\phi_{0}-\frac{e V}{2}-\frac{2 a \phi_{0}}{s} \ln \left[\frac{z+s}{z-s}\right] .
$$

Note that for small values of $V$ and $\zeta=0$, Equation 5.8 reduces to Equation 5.3 and Equation 5.5 reduces to Equation 5.1. 


\subsubsection{Current-distance spectroscopy}

An often used and reasonably accurate way of determining $\phi$ from I(z) measurements consists of plotting the natural logarithm of the conductance $G$ of the tunnelling barrier as a function of $z$. The conductance is equal to the measured tunnelling current divided by the tip-sample bias, i.e. $G=\frac{I}{V}$. The linear slope of the obtained line is then approximately equal to $\kappa$, as can be deduced from Equations 5.1 and 5.2. In the absence of image charge effects, the work function $\phi_{0}$ can then be obtained via Equation 5.4.

The same method can be used when including the effect of image charges, although the inverse decay length will take a slightly different form:

$$
\kappa^{*}=\alpha \sqrt{\phi-\frac{4 a \phi}{z}} .
$$

It is directly apparent that a significant image charge effect will have a bending effect on the $\ln (G)$ vs. $z$ curve. However, a quantitative analysis is made difficult by the non-straightforward dependence of $\kappa^{*}$ on $\zeta$.

In order to make a quantitative analysis possible, a numerical method will have to be developed. As a starting point, Equation 5.5 will have to be rewritten to eliminate as many unknown parameters as possible. By taking the derivative $\frac{d I}{d z}$, the density of states $\rho$ can be eliminated from the equation as follows:

$$
\begin{aligned}
\frac{d I}{d z} & =-\frac{\rho V}{s^{2}} \frac{d s}{d z} \sqrt{\phi} e^{-\alpha s \sqrt{\phi}}+\frac{\rho V}{s} \frac{1}{2 \sqrt{\phi}} \frac{d \phi}{d z} e^{-\alpha s \sqrt{\phi}} \\
& -\frac{\rho V}{s} \sqrt{\phi} e^{-\alpha s \sqrt{\phi}}\left[\alpha \sqrt{\phi} \frac{d s}{d z}+\frac{\alpha s}{2 \sqrt{\phi}} \frac{d \phi}{d z}\right] .
\end{aligned}
$$

Substituting Equation 5.5 then gives

$$
\frac{d I}{d z}=-\frac{I}{s} \frac{d s}{d z}+\frac{I}{2 \phi} \frac{d \phi}{d z}-I\left[\alpha \sqrt{\phi} \frac{d s}{d z}+\frac{\alpha s}{2 \sqrt{\phi}} \frac{d \phi}{d z}\right] .
$$

For the sake of brevity, the image charge term from Equation 5.8 can be redefined as

$$
M(z)=\frac{2 a \phi_{0}}{s} \ln \left[\frac{z+s}{z-s}\right]
$$


which leads to

$$
\frac{d \phi}{d z}=-\frac{d M}{d z}
$$

This derivative can be determined by using the product rule:

$$
\frac{d M}{d z}=\ln \left[\frac{z+s}{z-s}\right] \frac{d}{d z} \frac{2 a \phi_{0}}{s}+\frac{2 a \phi_{0}}{s} \frac{d}{d z} \ln \left[\frac{z+s}{z-s}\right] .
$$

The first part of this equation then yields

$$
\ln \left[\frac{z+s}{z-s}\right] \frac{d}{d z} \frac{2 a \phi_{0}}{s}=-\frac{2 a \phi_{0}}{s^{2}} \frac{d s}{d z} \ln \left[\frac{z+s}{z-s}\right],
$$

while the second part gives

$$
\begin{aligned}
& \frac{2 a \phi_{0}}{s} \frac{d}{d z} \ln \left[\frac{z+s}{z-s}\right] \\
& =\frac{2 a \phi_{0}}{s}\left[\frac{z-s}{z+s}\right]\left[\frac{1+\frac{d s}{d z}}{z-s}-\frac{(z+s)\left(1-\frac{d s}{d z}\right)}{(z-s)^{2}}\right] \\
& =\frac{2 a \phi_{0}}{s}\left[\frac{1+\frac{d s}{d z}}{z+s}-\frac{1-\frac{d s}{d z}}{z-s}\right]=\frac{4 a \phi_{0}}{s}\left[\frac{z \frac{d s}{d z}-s}{z^{2}-s^{2}}\right] .
\end{aligned}
$$

Equation 5.12 can be substituted into Equation 5.15 for further simplification, after which combination with Equation 5.16 finally yields

$$
\frac{d M}{d z}=\frac{4 a \phi_{0}}{s}\left[\frac{z \frac{d s}{d z}-s}{z^{2}-s^{2}}\right]-\frac{M}{s} \frac{d s}{d z} .
$$

Inserting everything back into Equation 5.11 and dividing by $I$ then gives the final expression

$$
\begin{aligned}
\frac{d I}{d z} / I & =-\frac{1}{s} \frac{d s}{d z}-\alpha \sqrt{\phi} \frac{d s}{d z} \\
& -\left[\frac{1}{2 \phi}-\frac{\alpha s}{2 \sqrt{\phi}}\right]\left[\frac{4 a \phi_{0}}{s}\left[\frac{z \frac{d s}{d z}-s}{z^{2}-s^{2}}\right]-\frac{M}{s} \frac{d s}{d z}\right]
\end{aligned}
$$

This resulting equation can be used to determine the work function $\phi_{0}$ and image charge constant $\zeta$ from a standard, open-loop I(z) measurement, as they are the only unknown variables remaining. These two unknowns can be extracted from measured data by fitting Equation 5.18 to the measured I(z) data in a least-squares fashion. 


\subsubsection{Constant-current spectroscopy}

When it is not possible, or not desirable, to perform experiments in openloop mode, the effective barrier can also be determined from closed-loop $\mathrm{z}(\mathrm{V})$ experiments. As is the case for $\mathrm{I}(\mathrm{z})$ measurements, plotting the natural logarithm of the conductance as a function of tip-sample separation yields a good first approximation of the inverse decay length. ${ }^{10,11}$ However, quantitatively decoupling the contributions of $\phi_{0}$ and $\zeta$ once again requires the use of a derivative numerical method. Taking into account that $I$ does not vary as a function of $V$ during closed-loop experiments, Equation 5.1 can be rewritten as:

$$
\begin{aligned}
I \frac{d s}{d V} & =\left(\frac{d \rho}{d V} V \sqrt{\phi}+\rho \sqrt{\phi}+\frac{\rho V}{2 \sqrt{\phi}} \frac{d \phi}{d V}\right) e^{-\alpha s \sqrt{\phi}} \\
& +\rho V \sqrt{\phi} e^{-\alpha s \sqrt{\phi}}\left(-\alpha \sqrt{\phi} \frac{d s}{d V}-\frac{\alpha s}{2 \sqrt{\phi}} \frac{d \phi}{d V}\right)
\end{aligned}
$$

Substituting Equation 5.5 into this expression and dividing by $I$ gives:

$$
\frac{d s}{d V}=\frac{d \rho}{d V} \frac{s}{\rho}+\frac{s}{V}+\frac{s}{2 \phi} \frac{d \phi}{d V}-s \alpha \sqrt{\phi} \frac{d s}{d V}-\frac{s^{2} \alpha}{2 \sqrt{\phi}} \frac{d \phi}{d V}
$$

Applying the chain rule, i.e.

$$
\frac{d s}{d V}=\frac{d s}{d z} \frac{d z}{d V}
$$

then leads to

$$
\frac{d s}{d z} \frac{d z}{d V}=\frac{d \rho}{d V} \frac{s}{\rho}+\frac{s}{V}+\frac{s}{2 \phi} \frac{d \phi}{d V}-s \alpha \sqrt{\phi} \frac{d s}{d z} \frac{d z}{d V}-\frac{s^{2} \alpha}{2 \sqrt{\phi}} \frac{d \phi}{d V} .
$$

When not including the image charge effect, $s=z$ and $\frac{d s}{d z}=1$ and the above equation reduces to:

$$
\frac{d z}{d V}=\frac{d \rho}{d V} \frac{z}{\rho}+\frac{z}{V}+\frac{z}{2 \phi} \frac{d \phi}{d V}-z \alpha \sqrt{\phi} \frac{d z}{d V}-\frac{z^{2} \alpha}{2 \sqrt{\phi}} \frac{d \phi}{d V} .
$$


When including neither the asymmetrical lowering of the barrier due to the applied bias voltage nor the lowering/narrowing effect of an image charge $\frac{d \phi}{d V}=0$ and Equation 5.22 can be rewritten as:

$$
\frac{d z}{d V}=\frac{\frac{d \rho}{d V} \frac{z}{\rho}+\frac{z}{V}}{1+z \alpha \sqrt{\phi}} .
$$

Including the asymmetric lowering of the barrier leads to $\frac{d \phi}{d V}=-\frac{e}{2}$ and

$$
\frac{d z}{d V}=\frac{\frac{d \rho}{d V} \frac{z}{\rho}+\frac{z}{V}-\frac{z e}{4 \phi}+\frac{z^{2} \alpha e}{4 \sqrt{\phi}}}{1+z \alpha \sqrt{\phi}} .
$$

Determining the derivative of the image charge term is slightly more involved. By once again defining

$$
M(z(V))=\frac{2 a \phi_{0}}{s} \ln \left[\frac{z+s}{z-s}\right]
$$

the notation can be kept relatively compact. Because $M$ only has an implicit dependence on $V$ via $z$, the chain rule can be used once again:

$$
\frac{d M}{d V}=\frac{d M}{d z} \frac{d z}{d V}
$$

leading to

$$
\frac{d \phi}{d V}=-\frac{e}{2}-\frac{d M}{d z} \frac{d z}{d V} .
$$

Inserting Equation 5.27 into Equation 5.21 gives the full expression

$$
\frac{d z}{d V}=\frac{\frac{d \rho}{d V} \frac{s}{\rho}+\frac{s}{V}-\frac{s e}{4 \phi}+\frac{s^{2} \alpha e}{4 \sqrt{\phi}}}{\frac{d s}{d z}+s \alpha \sqrt{\phi} \frac{d s}{d z}-\left[\frac{s^{2} \alpha}{2 \sqrt{\phi}}-\frac{s}{2 \phi}\right] \frac{d M}{d z}}
$$

with $\frac{d M}{d z}$ given by Equation 5.17.

Using a least-squares fitting routine with parameters $\phi_{0}$ and $\zeta$, one can fit Equation 5.28 to the $\frac{d z}{d V}$ data obtained from the experiment and, as such, determine the work function and image charge constant of the system.

An important limitation to the use of $\mathrm{z}(\mathrm{V})$ measurements for the determination of the effective barrier height arises due to the density of states (DOS) 
of the studied sample. For samples with a featureless or weakly varying DOS, measured at limited bias voltages, the $\frac{d \rho}{d V} \frac{s}{\rho}$ term in Equation 5.28 can be neglected. However, for non-featureless densities of states, the LDOS of the tip and sample will have to be known in order to fully evaluate Equation 5.28. This necessitates additional or consecutive measurements in order to obtain the system LDOS, ${ }^{5-8}$ as also described in Chapter 3.

\subsection{Experimental}

Experiments were performed on an RHK ultra-high vacuum system at room temperature and a base pressure of $1 \times 10^{-10}$ mbar. Measurement data was collected on a hydrogen flame-annealed $\mathrm{Au}(111)$ sample using an electrochemically etched W tip. The sample and tip had both been exposed to ultra-high vacuum conditions for several weeks prior to measuring. Spectroscopy traces were acquired using an RHK IVP-200 preamplifier at a fixed gain of $1 \times 10^{8} \mathrm{~V} \mathrm{~A}^{-1}$ and were performed within a short timeframe to minimise the effects of drift and possible changes to the tip or sample.

Experimental parameters were chosen to prevent changes in tip-sample distance between experiments. As such, $\mathrm{z}(\mathrm{V})$ measurements were performed at a setpoint current of $2 \mathrm{nA}$ over a range of $1 \mathrm{~V}$ to $0.05 \mathrm{~V}$. Subsequently, $\mathrm{I}(\mathrm{z})$ measurements were performed at a current setpoint of $2 \mathrm{nA}$ and a bias setpoint of $1 \mathrm{~V}$. The $\mathrm{I}(\mathrm{z})$ and $\mathrm{z}(\mathrm{V})$ measurements presented in this chapter are based on an average of 200 traces per measurement.

\subsection{Results and Discussion}

To determine the effect of $\zeta$ on $\phi_{0}$, three different sets of fit parameters were used: no image charge $(\zeta=0)$, maximum image charge $(\zeta=1)$ and variable image charge. The $\frac{d I}{d z}$ signal determined from the measurement and the traces that were reconstructed from the fitted parameters can be seen in Figure 5.1A. The most obvious conclusion that can be drawn from the obtained values of $\phi_{0}$ and $\zeta$ is that the two are coupled, with an increase in one leading to an increase in the other. While there is a difference of $0.5 \mathrm{eV}$ between $\phi_{0}$ for the optimal fit and $\phi_{0}$ in absence of an image charge, this seems to have little to no effect on the reconstructed signal. This shows that it is quite difficult to discriminate between the contributions of the effective work function and the image charge, as a change in one variable can be 


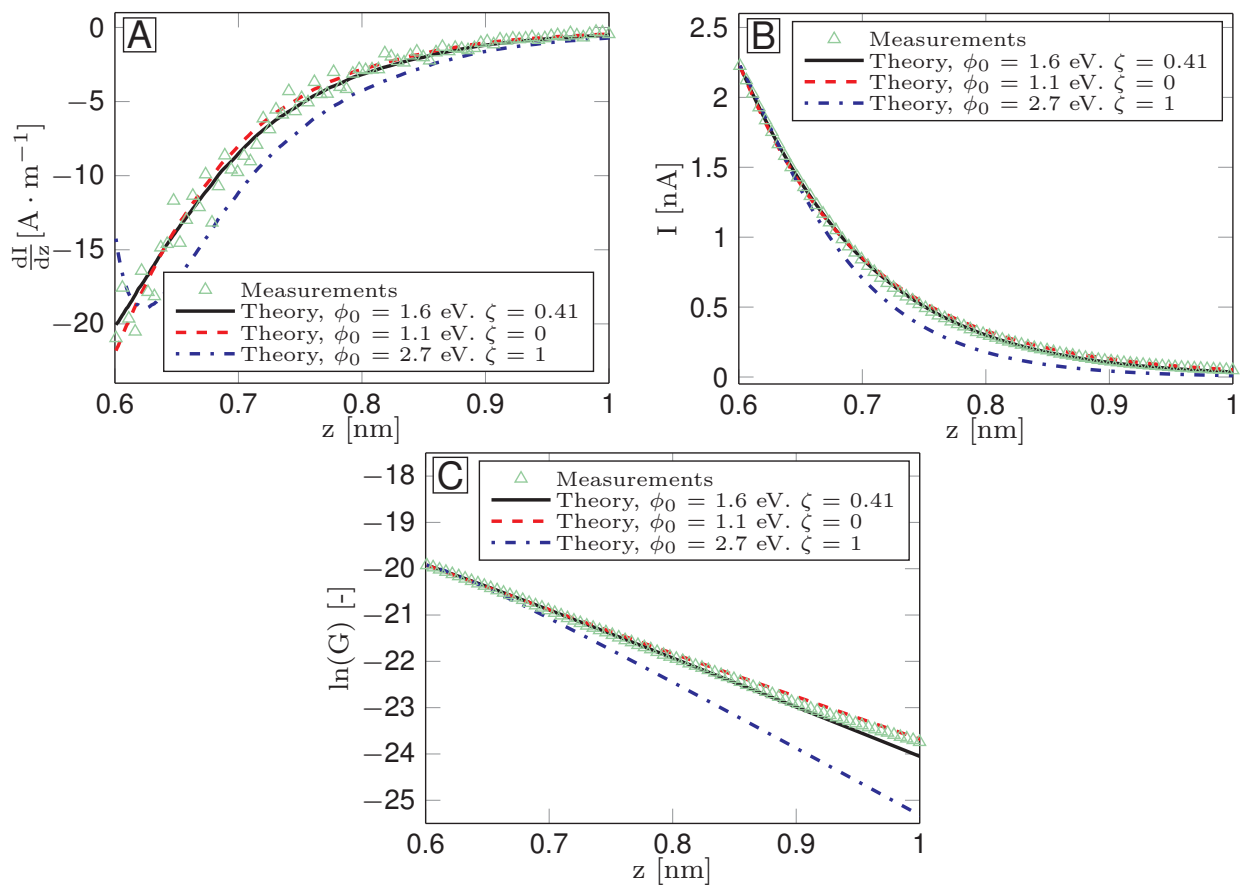

Figure 5.1: A) Measured and reconstructed $\frac{d I}{d z}$ data obtained from $\mathrm{I}(\mathrm{z})$ measurements. B) Measured and reconstructed I(z) data. C) Logarithmic conductance versus tip-sample distance for measured and reconstructed $\mathrm{I}(\mathrm{z})$ data.

readily masked by a change in the other. The reconstructed trace for $\zeta=1$, however, shows that there is a limit to this masking effect. For higher values of $\zeta, \phi$ becomes more strongly dependent on $z$, which manifests itself in a change in curvature for the $\frac{d I}{d z}$ signal.

Figure 5.1B shows the reconstructed current signals alongside the measured $\mathrm{I}(\mathrm{z})$ curve. All curves have been normalised to have the same starting point of roughly $2.2 \mathrm{nA}$ at $z_{0}=0.6 \mathrm{~nm}$. This value for $z_{0}$ was estimated based on previous STM measurements ${ }^{16}$ and will be used for all following analysis. Changing this value by a few $\AA$ does not significantly impact the results of the analysis. Figure 5.1B further emphasises the difficulty in discriminating between the measured signal, the optimal fit reconstruction, and the reconstruction that does not incorporate image charge effects. The image also shows the decrease in curvature for the $\zeta=1$ trace, although the difference 

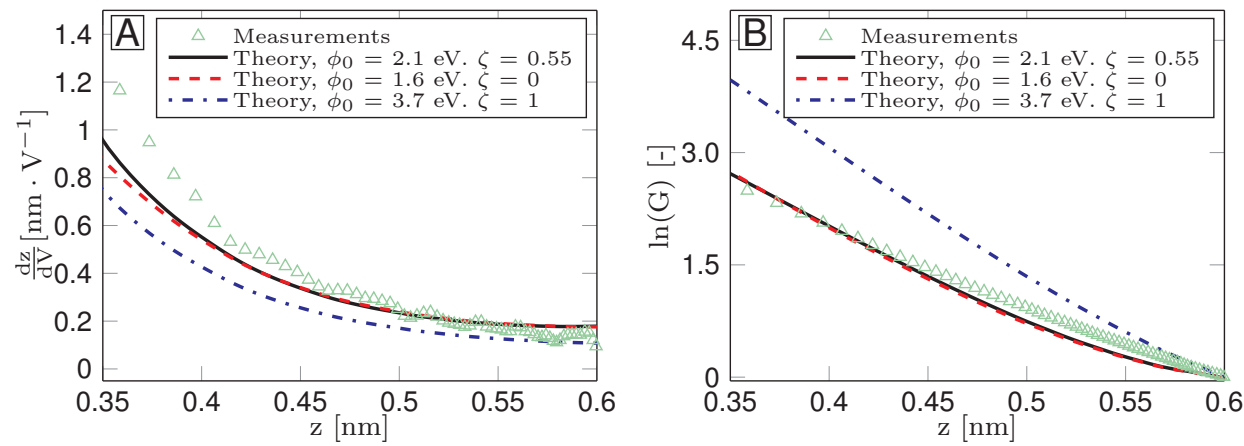

Figure 5.2: A) Measured and reconstructed $\frac{d z}{d V}$ traces obtained from $\mathrm{z}(\mathrm{V})$ measurements. B) Logarithmic conductance versus tip-sample distance for measured and reconstructed $\mathrm{z}(\mathrm{V})$ data. The logarithmic offsets have been subtracted so that $\ln (G)=0$ at $z_{0}=0.6$ nm.

between this trace and the measured signal is still rather small.

In order to further elucidate the effect of the image charge on the tunnelling current, the logarithm of the measured and reconstructed conductance has been plotted in Figure 5.1C as a function of z. As mentioned in Section 5.2, the slope of these traces is equal to the inverse decay length $\kappa^{*}$. Figure $5.1 \mathrm{C}$ clearly shows the effect of including the image charge when reconstructing the tunnelling current. While the effect is negligible for small tip-sample separation, the inclusion of an image charge term introduces a clear deviation from the linear trend observed for the reconstructed non-image charge current at larger separations. This same non-linearity is observed in the logarithm of the measured conductance, proving the need for the inclusion of a $z$ dependent term in $\phi$.

Figure 5.2A shows the measured and reconstructed $\frac{d z}{d V}$ traces. The difference between the optimal fit parameters and those obtained via the fit excluding image charge effects is very similar to that observed for the $\mathrm{I}(\mathrm{z})$ measurements. In addition, the difference between the reconstructed traces is practically invisible due to the masking effect of $\phi_{0}$ on lower values of $\zeta$. Forcing a maximum image charge contribution leads to an increase of $1.6 \mathrm{eV}$ in $\phi_{0}$, but also decreases the quality of the fit.

The conductance plots shown in Figure 5.2B were obtained in the same manner as the $\mathrm{I}(\mathrm{z})$ conductance plots with the important difference that the 


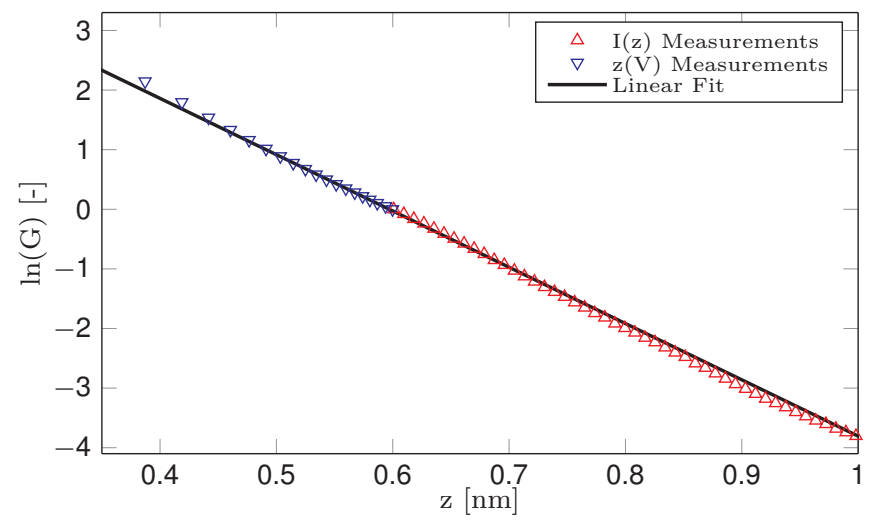

Figure 5.3: Combined logarithmic conductance versus tip-sample distance for $\mathrm{z}(\mathrm{V})$ and $\mathrm{I}(\mathrm{z})$ measurements. Logarithmic offsets for both types of measurements were zeroed at $z_{0}=0.6 \mathrm{~nm}$. The linear fit has a slope of $-10.4 \mathrm{~nm}^{-1}$.

offsets were subtracted to ensure that all curves start at $z_{0}=0.6 \mathrm{~nm}$. While the reconstructed $\mathrm{I}(\mathrm{z})$ curves can be scaled to have the same setpoint current, this same method can not be applied to the $\mathrm{z}(\mathrm{V})$ data. Instead, Equation 5.5 is used to reconstruct the (constant) current by using $\rho=1$. This does not influence the slope of the obtained conductance curves, but it will introduce different offsets for each curve, which is why it is necessary to zero them on a common point. The conductance plot obtained in this manner (Figure 5.2B) reveals a prominent curvature around $z=0.55 \mathrm{~nm}$ for the fitted parameters that is not present in the measurements. Additionally, the optimal fit and the fit excluding image charges perfectly overlap, further demonstrating the masking effect of $\phi_{0}$ and $\zeta$. The overall quality of the fitted traces is lower than that of the fitted $\mathrm{I}(\mathrm{z})$ traces. This could indicate an additional or stronger dependence of the tunnelling current on the applied bias voltage or tip-sample separation than is present in the used model.

By plotting the results of both $\mathrm{I}(\mathrm{z})$ and $\mathrm{z}(\mathrm{V})$ measurements in one figure, the equivalence of both methods can be demonstrated. Figure 5.3 shows the conductance data obtained from the $\mathrm{I}(\mathrm{z})$ and $\mathrm{z}(\mathrm{V})$ measurements, alongside a linear fit. The offsets of both data sets have been removed to ensure their intersection at $z=0.6 \mathrm{~nm}$. From this Figure, it is clear that the different types of measurements blend together practically seamlessly and that their slopes match closely. The fitted slope is equal to $-10.4 \mathrm{~nm}^{-1}$; approximately twice 
as small as the theoretical value. This leads to an effective barrier of $1 \mathrm{eV}$; approximately four to five times as small as the theoretical value. ${ }^{20,21}$ Measurements performed with different $\mathrm{W}$ tips and/or different $\mathrm{Au}(111)$ samples yielded similar barrier heights.

Despite the fact that the conductance plots of the $\mathrm{I}(\mathrm{z})$ and $\mathrm{z}(\mathrm{V})$ measurements demonstrate that both methods are equally viable for the determination of the effective tunnelling barrier, the obtained values for $\phi$ and $\phi_{0}$ are lower than they should be according to theory. Additionally, the fitted parameters for the $z(V)$ and $I(z)$ measurements are not fully consistent and the fits themselves are not as accurate as one would hope. Abnormally low barriers obtained via STS studies have been reported in the past, with a variety of possible reasons being suggested. ${ }^{22-27}$

As early as 1982, Binnig et al. reported work functions below $1 \mathrm{eV}$ for a tungsten-platinum system, which they ascribed to poor vacuum conditions and contamination. ${ }^{22}$ Similarly, the presence of water layers in the tunnelling junction can also lead to lower apparent barrier heights. ${ }^{25,28}$ However, the measurements presented in this chapter have been performed under UHV conditions, making it unlikely that (water) contamination is the cause of the low apparent barrier heights extracted from them.

Erroneous barrier heights can also be caused by misinterpretation of the tip-sample separation due to relaxation effects. ${ }^{27,29,30}$ According to experimental results and theoretical calculations, these effects only take place at tip-sample separations below $500 \mathrm{pm}$, i.e. in the $\mathrm{z}(\mathrm{V})$ regime of Figure 5.3. As such, any relaxation effects will be negated by the active feedback loop during $\mathrm{z}(\mathrm{V})$ measurements. If this were not the case, the onset of relaxation effects below $500 \mathrm{pm}$ should lead to a change in the slope of the measurements presented in Figure 5.3. Following the same line of reasoning, it is implausible that short-range electrostatic and exchange-interactions as suggested by Lang ${ }^{24}$ are responsible for the low extracted barrier values.

In order to analyse direct tunnelling experiments on large-area molecular junctions, Akkerman et al. included an additional exponential scaling factor in the Simmons model, which they later ascribed to the effective mass of the electrons tunnelling through the molecules. ${ }^{26} \mathrm{~A}$ similar effective mass correction has also been applied to tunnelling junctions consisting of a single molecule attached to both the STM tip and the sample and to tip-moleculevacuum-sample junctions. ${ }^{31-33}$ While a non-unity effective mass does indeed lead to lower apparent barrier heights, the tip-vacuum-sample system de- 

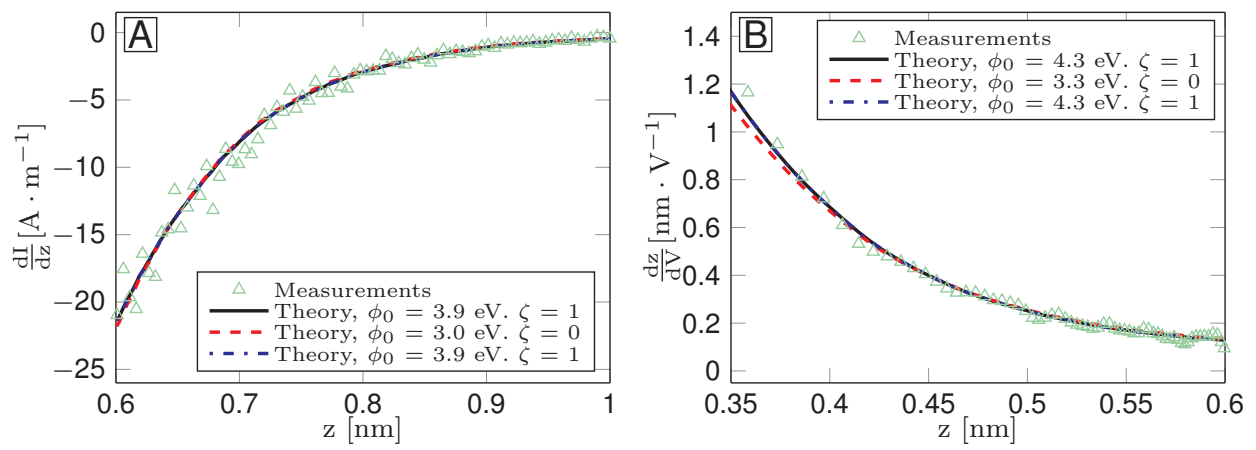

Figure 5.4: A) Measured and reconstructed $\frac{d I}{d z}$ data obtained from $\mathrm{I}(\mathrm{z})$ measurements for $\gamma=0.5$. B) Measured and reconstructed $\frac{d z}{d V}$ traces obtained from $\mathrm{z}(\mathrm{V})$ measurements for $\gamma=0.5$.

scribed in this chapter should not contain any periodic variations that could lead to the emergence of such an effective mass.

By introducing an additional scaling factor $\gamma$ in the Simmons model, analogous to Akkerman et al. ${ }^{26}$ the performance of the fitting model can be assessed for data values that result in a barrier height that is closer to theoretical values. Equation 5.5 is rewritten in the following form:

$$
I=\frac{\rho V \sqrt{\phi}}{s} e^{-\alpha \gamma \sqrt{\phi} s} .
$$

Based on the linear slope extracted from Figure 5.3, $\gamma$ was chosen to be equal to 0.5. As can be seen in Figures 5.4A and 5.4B, the introduction of $\gamma$ has three major consequences. Firstly, the quality of both fits increases dramatically, especially for the $\mathrm{z}(\mathrm{V})$ data. Secondly, the obtained values for $\phi_{0}$ and $\zeta$ are now consistent between measurements, with only a $0.4 \mathrm{eV}$ difference in $\phi_{0}$ between the $\mathrm{I}(\mathrm{z})$ and $z(\mathrm{~V})$ measurements. Finally, the influence of the different fitted parameters on the shape of the reconstructed curves has diminished sharply, with all three curves overlapping for both types of measurements. In other words, while the mutual masking effect between $\phi_{0}$ and $\zeta$ remains, the effective barrier $\phi$ is largely unaffected by changes in these parameters. This is consistent with a theoretical analysis performed by Coombs et al., ${ }^{19}$ which showed that the effect of an image charge on the apparent tunnelling barrier height is not readily extracted from $\mathrm{I}(\mathrm{z})$ data. While the exact origin of $\gamma$ is unclear, it is undeniable that its inclusion increases both the quality of the fits and the accuracy of the obtained values. 


\subsection{Conclusions}

The conductances obtained from $\mathrm{I}(\mathrm{z})$ and $\mathrm{z}(\mathrm{V})$ spectroscopy can both be used to get a good indication of the effective tunnelling barrier height $\phi$ when plotted logarithmically as a function of tip-sample separation. This means that the determination of the (local) work function of a material can be performed purely in the closed-loop operation mode present in all STM systems. Numerical analysis reveals a strong masking interaction between $\phi_{0}$ and $\zeta$, showing that neglecting the presence of an image charge can lead to one underestimating the value of $\phi_{0}$.

The inclusion of an additional scaling factor $\gamma$ has a positive impact on both the quality of the numerical fits as well as the values obtained from them. The exact physical origin of this term is, as of yet, unknown.

\section{Bibliography}

[1] G. Binnig, H. Rohrer, C. Gerber \& E. Weibel. Surface Studies by Scanning Tunneling Microscopy. Phys. Rev. Lett. 49, 57-61 (1982).

[2] R. M. Feenstra. Scanning tunneling spectroscopy. Surf. Sci. 299/300, 965 - 979 (1994).

[3] M. F. Crommie, C. P. Lutz \& D. M. Eigler. Imaging standing waves in a two-dimensional electron gas. Nature 363, 524-527 (1993).

[4] R. Heimbuch, M. Kuzmin \& H. J. W. Zandvliet. Origin of the $\mathrm{Au} / \mathrm{Ge}(001)$ metallic state. Nat. Phys. 8, 697-698 (2012).

[5] M. Ziegler, N. Néel, A. Sperl, J. Kröger \& R. Berndt. Local density of states from constant-current tunneling spectra. Phys. Rev. B 80, 125402 (2009).

[6] A. Pronschinske, D. J. Mardit \& D. B. Dougherty. Modeling the constant-current distance-voltage mode of scanning tunneling spectroscopy. Phys. Rev. B 84, 205427 (2011).

[7] C. Hellenthal, R. Heimbuch, K. Sotthewes, E. S. Kooij \& H. J. W. Zandvliet. Determining the local density of states in the constant current STM mode. Phys. Rev. B 88, 035425 (2013). 
[8] B. V. C. Martins, M. Smeu, L. Livadaru, H. Guo \& R. A. Wolkow. Conductivity of $\mathrm{Si}(111)-(7 \times 7)$ : The Role of a Single Atomic Step. Phys. Rev. Lett. 112, 246802 (2014).

[9] G. Binnig, N. Garcia, H. Rohrer, J. M. Soler \& F. Flores. Electronmetal-surface interaction potential with vacuum tunneling: Observation of the image force. Phys. Rev. B 30, 4816-4818 (1984).

[10] M. Payne \& J. Inkson. Measurement of workfunctions by tunnelling and the effect of the image potential. Surf. Sci. 159, 485 - 495 (1985).

[11] J. Pitarke, P. Echenique \& F. Flores. Apparent barrier height for tunneling electrons in STM. Surf. Sci. 217, 267 - 275 (1989).

[12] K. Gundlach. Zur berechnung des tunnelstroms durch eine trapezförmige potentialstufe. Solid-State Electron. 9, 949 - 957 (1966).

[13] C. L. Lin, S. M. Lu, W. B. Su, H. T. Shih, B. F. Wu, Y. D. Yao, C. S. Chang \& T. T. Tsong. Manifestation of Work Function Difference in High Order Gundlach Oscillation. Phys. Rev. Lett. 99, 216103 (2007).

[14] J. M. Beebe, B. S. Kim, J. W. Gadzuk, C. D. Frisbie \& J. G. Kushmerick. Transition from Direct Tunneling to Field Emission in Metal-MoleculeMetal Junctions. Phys. Rev. Lett. 97, 026801 (2006).

[15] M. L. Trouwborst, C. A. Martin, R. H. M. Smit, C. M. Guédon, T. A. Baart, S. J. van der Molen \& J. M. van Ruitenbeek. Transition Voltage Spectroscopy and the Nature of Vacuum Tunneling. Nano Lett. 11, 614-617 (2011).

[16] K. Sotthewes, V. Geskin, R. Heimbuch, A. Kumar \& H. J. W. Zandvliet. Research Update: Molecular electronics: The single-molecule switch and transistor. APL Materials 2, 01070101 - 01070111 (2014).

[17] J. G. Simmons. Generalized Formula for the Electric Tunnel Effect between Similar Electrodes Separated by a Thin Insulating Film. $J$. Appl. Phys. 34, 1793-1803 (1963).

[18] E. H. Huisman, C. M. Guédon, B. J. van Wees \& S. J. van der Molen. Interpretation of Transition Voltage Spectroscopy. Nano Lett. 9, 39093913 (2009). 
[19] J. Coombs, M. Welland \& J. Pethica. Experimental barrier heights and the image potential in scanning tunneling microscopy. Surf. Sci. 198, L353-L358 (1988).

[20] P. A. Anderson. Work Function of Gold. Phys. Rev. 115, 553-554 (1959).

[21] W. Sachtler, G. Dorgelo \& A. Holscher. The work function of gold. Surf. Sci. 5, $221-229$ (1966).

[22] G. Binnig, H. Rohrer, C. Gerber \& E. Weibel. Tunneling through a controllable vacuum gap. Appl. Phys. Lett. 40, 178-180 (1982).

[23] J. K. Gimzewski \& R. Möller. Transition from the tunneling regime to point contact studied using scanning tunneling microscopy. Phys. Rev. B 36, 1284-1287 (1987).

[24] N. D. Lang. Apparent barrier height in scanning tunneling microscopy. Phys. Rev. B 37, 10395-10398 (1988).

[25] J. Ahn \& M. Pyo. Comparison of STM Barrier Heights on HOPG in Air and Water. Bull. Korean Chem. Soc. 21, 644-646 (2000).

[26] H. B. Akkerman, R. C. G. Naber, B. Jongbloed, P. A. van Hal, P. W. M. Blom, D. M. de Leeuw \& B. de Boer. Electron tunneling through alkanedithiol self-assembled monolayers in large-area molecular junctions. Proc. Natl. Acad. Sci. U.S.A. 104, 11161-11166 (2007).

[27] C. Lazo, N. Néel, J. Kröger, R. Berndt \& S. Heinze. Tunneling magnetoresistance and exchange interaction in single-atom contacts. Phys. Rev. B 86, 180406 (2012).

[28] J. Halbritter, G. Repphun, S. Vinzelberg, G. Staikov \& W. Lorenz. Tunneling mechanisms in electrochemical STM - distance and voltage tunneling spectroscopy. Electrochim. Acta 40, 1385 - 1394 (1995).

[29] W. A. Hofer, A. J. Fisher, R. A. Wolkow \& P. Grütter. Surface Relaxations, Current Enhancements, and Absolute Distances in High Resolution Scanning Tunneling Microscopy. Phys. Rev. Lett. 87, 236104 (2001). 
[30] J. M. Blanco, C. González, P. Jelínek, J. Ortega, F. Flores \& R. Pérez. First-principles simulations of STM images: From tunneling to the contact regime. Phys. Rev. B 70, 085405 (2004).

[31] J. Zhou, C. Guo \& B. Xu. Electron transport properties of single molecular junctions under mechanical modulations. J. Phys.: Condens. Matter 24, 164209 (2012).

[32] K. Sotthewes, R. Heimbuch \& H. J. W. Zandvliet. Manipulating transport through a single-molecule junction. J. Chem. Phys. 139, 2147091 -2147095 (2013).

[33] K. Wang, J. Zhou, J. M. Hamill \& B. Xu. Measurement and understanding of single-molecule break junction rectification caused by asymmetric contacts. J. Chem. Phys. 141, $0547121-0547127$ (2014). 


\section{Investigating the nature of the quantum mechanical tunnelling gap in non-vacuum conditions}

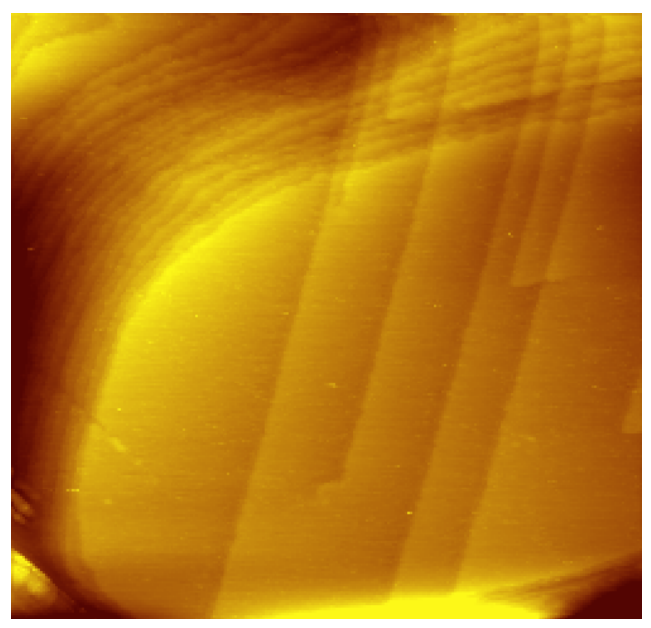

In order to obtain a more thorough understanding of the nature of the quantum tunnelling junction in STM and STS experiments, these experiments were carried out in a variety of different environments. By determining the effective barrier in ambient and a number of different solvents, the influence of the gap conditions on tunnelling parameters has been studied. While tunnelling remains the primary charge transfer mechanism for all investigated junctions, measurements performed in liquid environments exhibit several characteristics that do not fit into the standard Simmons model. 


\subsection{Introduction}

Only a few years after the introduction of Scanning Tunnelling Microscopy $(\mathrm{STM}),{ }^{1}$ the technique was adapted for use in aqueous ${ }^{2}$ and potentiostatically controlled ${ }^{3}$ environments. Since then, the electrochemical STM (ECSTM) has been used for the characterisation of numerous different sampleelectrolyte systems. ${ }^{4-7}$ However, while the use of the topographic mode of ECSTM has been widely reported in literature, articles dealing with scanning tunnelling spectroscopy (STS) in liquid environment are relatively rare and mostly limited to aqueous electrolytes. ${ }^{8,9}$ As is the case with regular vacuum STM, the limited dimensions of the tip-liquid-sample junction enable one to generate a very high, very local electric field in ECSTM spectroscopy. It has been proposed, based on previous research, ${ }^{10}$ that this effect could be used in an energy-efficient way of generating solvated electrons in common solvents such as water and ethanol, providing an alternative to the current industrial standard of dissolving alkali metals in liquid ammonia.

Recent years have seen a surge in STM activity within the field of molecular electronics. Extensive research has been performed both on single molecules, ${ }^{11-13}$ as well as ensembles of molecules and (self-assembled) monolayers. ${ }^{13,14}$ While these systems constitute quite the departure from 'classical' STM vacuum junctions, most papers still attempt to describe them using a modified version of the Simmons model. ${ }^{15}$ These modifications include visualising the tunnel junction as a series of distinct junctions with their own parameters, ${ }^{16-18}$ or as a single junction with altered characteristics based on the molecules under consideration. ${ }^{11,19,20}$

As pointed out by McCreery in $2012,{ }^{20}$ many concepts within the field of molecular electronics are derived from electrochemistry. As such, investigating the nature of the tunnelling barrier within an electrochemical environment can lead to insights that are also applicable within the field of molecular electronics. An advantage of ECSTM measurements when compared to STM measurements performed on molecular junctions, is that the electrolyte under consideration does not need to be strongly bonded to the substrate. Conversely, this does lead to a certain amount of ambiguity about the orientation of the solvent molecules within the tunnelling junction.

In this chapter, STS I(z) measurements in ambient and liquid environment are presented and analysed. Through the use of the model introduced in Chapter 5, the effective barriers and inverse decay lengths of these different 

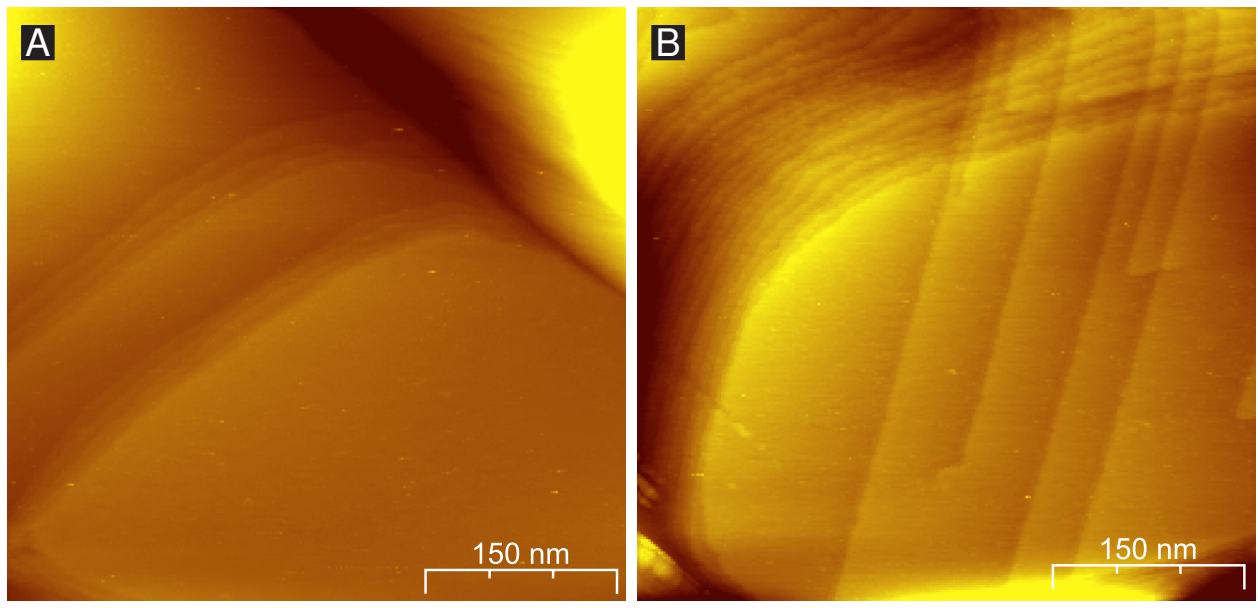

Figure 6.1: $\mathrm{Au}(111)$ topography images recorded A) in ethanol and B) in decanol. Spectroscopy measurements were performed in the middle of the large terraces.

junctions are determined. While the extracted tunnelling barriers in liquids are significantly lower than their vacuum counterpart, the measured current is still exponentially dependent on the tip-sample separation, indicating that tunnelling remains the most important method of charge transfer.

\subsection{Experimental}

All experiments were performed in a home-built ECSTM setup, controlled using an RHK Rev9 hardware/software module. Electrochemical control and cyclic voltammetry measurements were provided by a home-built potentiostat. See Chapter 2 for further information. Tips were prepared by the angular cutting of $1.5 \mathrm{~cm}$ long, $0.25 \mathrm{~mm}$ diameter platinum-iridium wire segments. These tips were subsequently coated with an isolating, chemically resistant polymer in order to minimise leakage currents in electrochemical environments. Pentanol $(\geq 99 \%), \operatorname{hexanol}(\geq 99 \%),[1,2,3]$-heptanol $(\geq 98 \%)$ and octanol $(\geq 99 \%)$ were purchased from Sigma Alderich in anhydrous form. $\operatorname{Methanol}(\geq 99 \%)$, ethanol, butanol $(\geq 99 \%)$ and decanol $(\geq 99 \%)$ were purchased from Merck. Au substrates $\left(11 \times 11 \mathrm{~mm}^{2}, 250 \mathrm{~nm} \mathrm{Au}\right.$ on $2 \mathrm{~nm} \mathrm{Cr}$ on borosilicate glass) for STM measurements were purchased from Arrandee 
(Werther, Germany). Au(111) samples were obtained by annealing the substrates in a high purity $\mathrm{H}_{2}$ flame for 5 min.

An important issue when dealing with spectroscopy in liquid environments is the amount of drift present during the measurements. While vacuum and ambient measurements also suffer from a certain amount of drift, finding a flat terrace of a few tens of nanometres wide is often enough to ensure that the tip remains on this terrace during the entire spectroscopy run. In liquid environments, drift vectors of several tens or even hundreds of picometres per second are not uncommon. Under these circumstances, numerous steps and terraces will pass underneath the tip during the spectroscopy measurements, leading to variations in the tip-sample distance that can not be easily accounted for. This additional drift is likely caused by convective flow due to the evaporation of the liquid.

In order to minimise the impact of the abovementioned drift, spectroscopy measurements were preceded by several topographic measurements (e.g. Figure 6.1) to assay the amount and general direction of drift for every measurement configuration. By doing so, suitably large terraces could be identified. In addition, by minimising the total measurement time, the chances of passing a large number of steps during the measurement process can be reduced. However, the desire for a short total measurement time is directly opposed to the need for sufficient spectra in order to be able to perform meaningful statistical analysis on the traces. In order to balance out these two competing requirements, the time per spectrum was minimised to $1.6 \mathrm{~s}$ for the $\mathrm{I}(\mathrm{z})$ traces. A total of 200 traces per measurement were acquired, which were subsequently filtered to remove obvious outliers before averaging them.

\subsection{Model}

The exact configuration of (solvent) molecules in the tunnelling junction and the effect of this configuration on the junction is unknown, making it difficult to determine the type of model to be used a priori. As such, the starting point for the analysis of the ECSTS measurements will be the same as that for vacuum and molecular STS measurements, i.e. the Simmons model: ${ }^{15}$

$$
I=\frac{\rho V \sqrt{\phi}}{s} e^{-\alpha \sqrt{\phi} s} .
$$


Here, $I$ is the tunnelling current, $\rho=\rho(V)$ is the energy dependent density of states of the tip and sample, $V$ is the applied tip-sample bias voltage, $s$ is the effective barrier width, $\phi$ is the tunnelling barrier height and $\alpha=2 \frac{\sqrt{2 m}}{\hbar}$, with $m$ the rest mass of the electron.

The tunnelling barrier is altered by the presence of image charges and the influence of the bias voltage between the tip and the sample. The effective barrier width $s$ can be determined from the tip-sample separation $z$ via the following formula: ${ }^{15,21}$

$$
s=z \sqrt{1-\frac{4 a}{z}}
$$

where

$$
a=\zeta \frac{1.15 e^{2} \ln (2)}{16 \pi \epsilon_{0} \phi_{0}} .
$$

The strength of the image charge effect is given by $0 \leq \zeta \leq 1$, depending on the geometry of the tunnelling junction. For two point charges $\zeta=0$, whereas $\zeta=1$ for two infinite parallel plates. The height of the potential barrier can be expressed as follows: ${ }^{15}$

$$
\phi(V, z)=\phi_{0}-\frac{e V}{2}-\frac{2 a \phi_{0}}{s} \ln \left[\frac{z+s}{z-s}\right] .
$$

In the absence of image charges and for low bias voltages, this expression simply reduces to the vacuum work function of the sample material, $\phi_{0}$.

In order to determine the contributions of $\phi_{0}$ and $\zeta$ on the effective tunnelling barrier, the measured I $(z)$ curves will have to be fitted to the theoretical model. All unknowns other than $\phi_{0}$ and $\zeta$ can be eliminated by dividing the derivative $\frac{d I}{d z}$ by the current $I$ as follows:

$$
\begin{aligned}
\frac{d I}{d z} / I & =-\frac{1}{s} \frac{d s}{d z}-\alpha \sqrt{\phi} \frac{d s}{d z} \\
& -\left[\frac{1}{2 \phi}-\frac{\alpha s}{2 \sqrt{\phi}}\right]\left[\frac{4 a \phi_{0}}{s}\left[\frac{z \frac{d s}{d z}-s}{z^{2}-s^{2}}\right]-\frac{M}{s} \frac{d s}{d z}\right],
\end{aligned}
$$

with

$$
M(z)=\frac{2 a \phi_{0}}{s} \ln \left[\frac{z+s}{z-s}\right] .
$$

A thorough derivation of this formula is given in Section 5.2. 

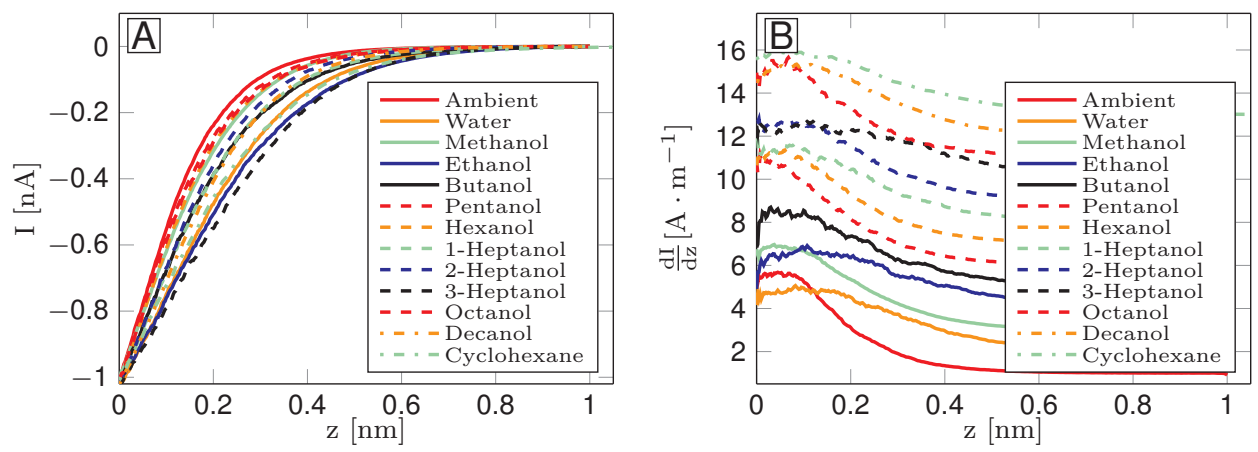

Figure 6.2: A) Measured $\mathrm{I}(\mathrm{z})$ curves for a variety of different tunnelling junctions. Offsets for all curves have been removed so that their end points lie at $I=0 \mathrm{nA}$. B) Derivative curves of the measurements shown in Figure A. Each curve has been given an offset in order to promote clarity.

\subsection{Results and Discussion}

The $\mathrm{I}(\mathrm{z})$ spectroscopy traces obtained in different tunnelling environments can be seen in Figure 6.2. Despite the fact that the decay rates for the different junctions vary over a significant range, all $\mathrm{I}(\mathrm{z})$ curves exhibit the typical exponential behaviour that is characteristic to tunnelling. As expected, the measurements performed in ambient show the sharpest decay, with the current dropping by a factor of two within $110 \mathrm{pm}$. In contrast, the tunnelling current in the 3-heptanol measurements takes approximately $220 \mathrm{pm}$ to decrease by the same factor.

Figure $6.2 \mathrm{~B}$ shows the $\frac{d I}{d z}$ signals associated with the measured $\mathrm{I}(\mathrm{z})$ curves. Remarkably, all measurements have a local maximum in their slope around $z=0.1 \mathrm{~nm}$, revealing that the tunnelling current does not behave perfectly exponentially during the first $100 \mathrm{pm}$ of the separation ramp. In order to exclude the possibility that this phenomenon is caused by an instrumentation error, a number of $\mathrm{I}(\mathrm{z})$ curves were recorded in water using different starting points. Figure 6.3 shows the results of these measurements. In all cases, the setpoint current at $z=0$ was chosen to be $1 \mathrm{nA}$. The tip was then retracted from, or brought closer to, the sample prior to starting the measurement. During the measurement itself, the tip was retracted from the sample. Bringing the tip closer to the sample prior to the measurement 

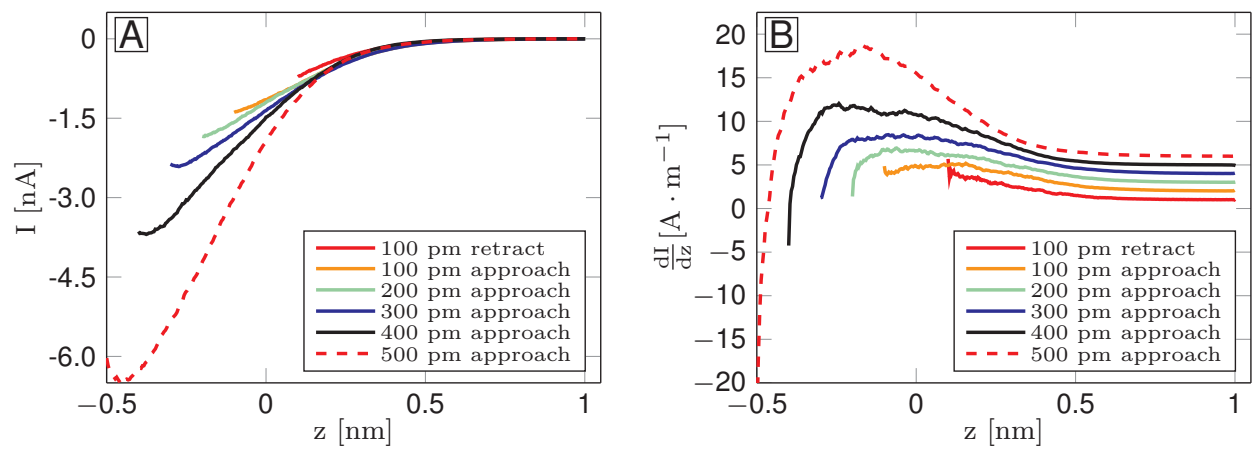

Figure 6.3: A) Measured $\mathrm{I}(\mathrm{z})$ curves for a variety of distance ramps in water. Offsets for all curves have been removed so that their end points lie at $I=0 \mathrm{nA}$. Negative z-values indicate that the tip was brought closer to the sample. B) Derivative curves of the measurements shown in Figure A. Each curve has been given an offset to promote clarity.

increases the curvature of the obtained signal, to the point where it is clearly visible in the $\mathrm{I}(\mathrm{z})$ characteristics for approach distances exceeding $200 \mathrm{pm}$. For these curves, the current initially increases as the distance between the tip and the sample is increased; a phenomenon that cannot be explained using the Simmons model. Altering acquisition times and stabilisation delays did not significantly change the observed behaviour, making it unlikely that it is caused by, e.g., piezo creep. A possible explanation for the observed effect could be the formation of a double layer around the tip and the sample, leading to the occurrence of intermediate tunnelling states. ${ }^{8}$ While the interaction between these double layers would be noticeable around $z_{0}$, retracting the tip will gradually decrease this interaction, as well as potentially disturb the double layer around the tip. This could also explain why the effect becomes more pronounced when the tip is first brought closer to the sample, as this would cause the distance between both double layers to decrease or possibly even cause the double layers to be brought into contact with each other. Regardless, further analysis of the obtained signals will focus on the exponential part of the $\mathrm{I}(\mathrm{z})$ curves. As such, the first $150 \mathrm{pm}$ of every measurement set was excluded from the analysis.

Analogous to the procedure followed in Chapter 5, the measured derivative signals were fitted to Equation 6.5 to determine the contributions of the 'work 
Chapter 6 Investigating the tunnelling gap in non-vacuum conditions

\begin{tabular}{|l|c|c|c|c|c|c|c|}
\hline & \multicolumn{6}{|c|}{ Measurements } & \multicolumn{2}{c|}{ Literature } \\
\cline { 2 - 8 } & $\phi_{0}[\mathrm{eV}]$ & $\zeta[-]$ & $\kappa\left[\mathrm{nm}^{-1}\right]$ & $\bar{\phi}[\mathrm{eV}]$ & $\phi_{\mathrm{eq}}[\mathrm{eV}]$ & $\epsilon_{\mathrm{r}}[-]^{22}$ & $\mathrm{~L}[\mathrm{pm}]^{22}$ \\
\hline Ambient (A) & $0.99_{-0.03}^{+0.01}$ & $0.95_{-0.02}^{+0.02}$ & $9.35_{-0.15}^{+0.03}$ & $0.20_{-0.01}^{+0.00}$ & $0.83_{-0.03}^{+0.00}$ & 1.00 & $\mathrm{~N} / \mathrm{A}$ \\
\hline Water (W) & $0.42_{-0.04}^{+0.08}$ & $0.40_{-0.04}^{+0.08}$ & $6.21_{-0.28}^{+0.53}$ & $0.08_{-0.01}^{+0.01}$ & $0.37_{-0.03}^{+0.07}$ & 80.1 & 171 \\
\hline Methanol (M) & $0.81_{-0.08}^{+0.12}$ & $0.78_{-0.07}^{+0.11}$ & $8.49_{-0.43}^{+0.59}$ & $0.16_{-0.02}^{+0.03}$ & $0.69_{-0.07}^{+0.10}$ & 33.0 & 308 \\
\hline Ethanol (E) & $0.35_{-0.05}^{+0.09}$ & $0.33_{-0.05}^{+0.09}$ & $5.71_{-0.39}^{+0.64}$ & $0.07_{-0.01}^{+0.02}$ & $0.31_{-0.04}^{+0.07}$ & 25.3 & 442 \\
\hline Butanol (B) & $0.50_{-0.08}^{+0.16}$ & $0.47_{-0.07}^{+0.15}$ & $6.78_{-0.56}^{+0.96}$ & $0.10_{-0.02}^{+0.04}$ & $0.44_{-0.07}^{+0.13}$ & 17.8 & 783 \\
\hline Pentanol (P) & $0.80_{-0.08}^{+0.16}$ & $0.77_{-0.09}^{+0.17}$ & $8.44_{-0.38}^{+0.74}$ & $0.16_{-0.01}^{+0.02}$ & $0.68_{-0.06}^{+0.12}$ & 15.1 & 906 \\
\hline Hexanol (H) & $0.72_{-0.01}^{+0.00}$ & $0.66_{-0.03}^{+0.01}$ & $8.09_{-0.09}^{+0.00}$ & $0.16_{-0.01}^{+0.00}$ & $0.62_{-0.01}^{+0.00}$ & 13.0 & 1029 \\
\hline 1-Heptanol (1H) & $0.53_{-0.06}^{+0.12}$ & $0.50_{-0.05}^{+0.02}$ & $6.96_{-0.41}^{+0.90}$ & $0.11_{-0.02}^{+0.08}$ & $0.46_{-0.05}^{+0.13}$ & 11.8 & 1152 \\
\hline 2-Heptanol $(2 \mathrm{H})$ & $0.67_{-0.11}^{+0.00}$ & $0.65_{-0.55}^{+0.00}$ & $7.74_{-0.33}^{+0.29}$ & $0.13_{-0.01}^{+0.29}$ & $0.57_{-0.05}^{+0.04}$ & 9.72 & 1041 \\
\hline 3-Heptanol (3H) & $0.34_{-0.08}^{+0.22}$ & $0.33_{-0.09}^{+0.22}$ & $5.56_{-0.59}^{+1.51}$ & $0.06_{-0.01}^{+0.04}$ & $0.29_{-0.06}^{+0.18}$ & 7.07 & 1041 \\
\hline Octanol (O) & $0.71_{-0.06}^{+0.00}$ & $0.65_{-0.55}^{+0.00}$ & $8.04_{-0.33}^{+0.59}$ & $0.16_{-0.03}^{+0.35}$ & $0.61_{-0.05}^{+0.09}$ & 10.3 & 1275 \\
\hline Decanol (D) & $0.63_{-0.05}^{+0.08}$ & $0.61_{-0.05}^{+0.07}$ & $7.51_{-0.29}^{+0.46}$ & $0.12_{-0.01}^{+0.02}$ & $0.54_{-0.04}^{+0.07}$ & 7.93 & 1521 \\
\hline Cyclohexane (C) & $0.42_{-0.09}^{+0.30}$ & $0.36_{-0.14}^{+0.43}$ & $6.34_{-0.50}^{+1.40}$ & $0.11_{-0.01}^{+0.02}$ & $0.38_{-0.06}^{+0.19}$ & 2.02 & 551 \\
\hline
\end{tabular}

Table 6.1: Analysis results and literature data for the measured solvents. A description of the various quantities is given in the text. Upper and lower error bounds were obtained from the analysis of the standard deviations of the mean curves.

function' $\phi_{0}$ and the image charge term $\zeta$. From these parameters, two barrier heights can be defined. The first one is the mean effective barrier height $\bar{\phi}$, which is the mean of the value given by Equation 6.4 and corresponds to the effective barrier width $s$. The second one is the equivalent barrier height $\phi_{\text {eq }}$, which can be determined from the slope of the reconstructed $\ln (I)$ vs. $z$ plot and corresponds to the tip-sample separation $z$. Regardless of which interpretation is chosen, the exponential decay of the $\mathrm{I}(\mathrm{z})$ curves can also be characterised by using the inverse decay length $\kappa$, i.e. the slope of the logarithmic current as a function of tip-sample separation. This last method circumvents the need to fully define the shape of the tunnelling barrier, capturing the essential information within a single number. The results of the analysis can be found in Table 6.1, alongside relevant parameters from literature for the studied liquids.

Figure 6.4A shows the inverse decay length as a function of the relative permittivity of the tunnelling environment. The upper and lower error bounds were determined from fitting the averaged curves plus or minus the standard deviation. The relative permittivity gives an indication of how readily a medium is polarised, making it a logical variable to consider in relation to 

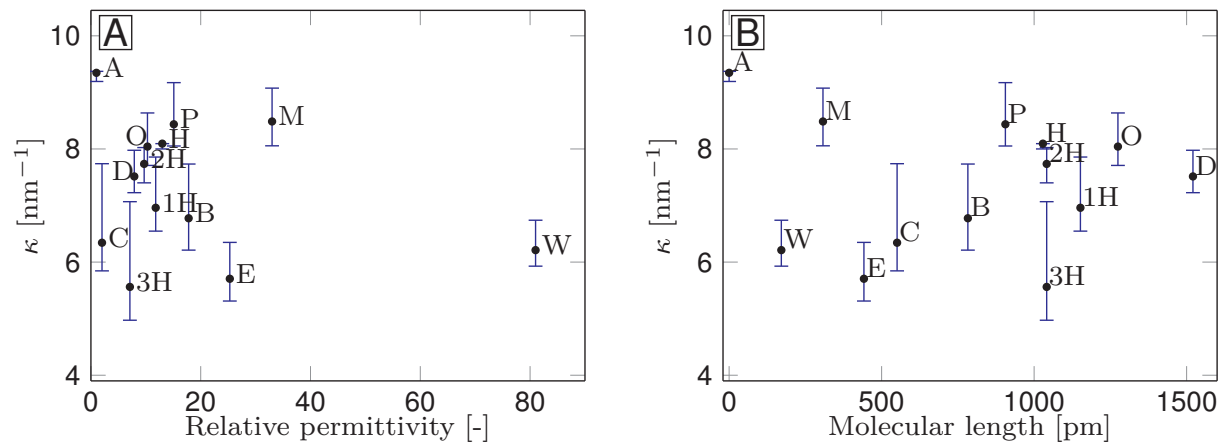

Figure 6.4: A) Inverse decay length as a function of relative permittivity. B) Inverse decay length as function of (approximate) molecule length. The error bars were determined from the standard deviations of the averaged measurements. The labels correspond to those given in Table 6.1.

the tunnelling barrier. A higher polarisation would lead to a lower effective electric field, which in turn would lead to a higher tunnelling barrier. The dipole moments of the individual molecules were also considered, but these values are practically equal for all studied molecules. Unfortunately, while it is possible to infer a directly proportional relationship between the relative permittivity and the tunnelling barrier from Figure 6.4A, the opposite is also true. As such, it is difficult to make a definitive statement about the influence of the relative permittivity on the tunnelling barrier. A theoretical paper by Sebastian and Doyen ${ }^{23}$ states that the time an electron spends in the barrier is far smaller than the time needed for the solvent molecules to respond to it, leading the authors to conclude that the polarisation of the liquid does not play a role in lowering the tunnelling barrier. However, they do not consider the effect a continuous stream of electrons might have on the liquid, nor that of the presence of the electric field between the tip and the sample.

Another possible factor influencing the tunnelling behaviour in solvent junctions is the length of the solvent molecules. Figure 6.4B shows the inverse decay length as a function of the approximate molecular lengths of the used solvents. The inverse decay length appears to slightly increase as a function of the molecular length. Previous studies on alkanethiols ${ }^{16,24}$ have shown that increasing the length of these molecules also leads to an increase in the inverse decay length. However, in liquid environment, this would re- 
quire that the molecules are, on average, aligned parallel to the junction, as the alcohols used in this study do not have thiol end-groups that bind to the sample surface. The presence of an electric field could cause the polar alcohol molecules to align in this manner, leading to an alternate tunnelling path.

It should be noted that methanol and ethanol are both highly hygroscopic, and the chemicals purchased from Merck have been in use for extended periods of time. It is therefore quite possible that the ethanol and methanol have been contaminated by appreciable amounts of water, explaining why the extracted parameters differ significantly from those extracted from the other solvents.

\subsection{Conclusions}

Scanning tunnelling spectroscopy measurements have been performed in a variety of environments. Regardless of the composition of the tunnelling junction, all measured $\mathrm{I}(\mathrm{z})$ characteristics show an exponential decay, indicating that charge transfer in these junctions is dominated by quantum mechanical tunnelling. The onset of the $\mathrm{I}(\mathrm{z})$ curves deviate from this trend, hinting at the possibility of additional processes occurring between the tip and the sample. Aside from a weak length dependence, there appears to be no clear trend in the barriers extracted from the presented measurements. However, it is clear that the nature of the tunnelling junction does significantly influence the current decay rate. Further study into a wider range of liquids is to be advised.

\section{Bibliography}

[1] G. Binnig, H. Rohrer, C. Gerber \& E. Weibel. Tunneling through a controllable vacuum gap. Appl. Phys. Lett. 40, 178-180 (1982).

[2] R. Sonnenfeld \& P. Hansma. Atomic-resolution microscopy in water. Science 232, 211-213 (1986).

[3] K. Itaya \& E. Tomita. Scanning tunneling microscope for electrochemistry - a new concept for the in situ scanning tunneling microscope in electrolyte solutions. Surf. Sci. 201, L507-L512 (1988). 
[4] A. A. Gewirth \& B. K. Niece. Electrochemical Applications of in Situ Scanning Probe Microscopy. Chem. Rev. 97, 1129-1162 (1997).

[5] O. M. Magnussen \& M. R. Vogt. Dynamics of Individual Atomic Kinks during Crystal Dissolution. Phys. Rev. Lett. 85, 357-360 (2000).

[6] P. Broekmann, M. Anastasescu, A. Spaenig, W. Lisowski \& K. Wandelt. Atomic structures and dynamics of a $\mathrm{Cu}(100)$ electrode in dilute hydrobromic acid: An in situ STM study. J. Electroanal. Chem. 500, 241 254 (2001).

[7] F. Endres. Ionic Liquids: Promising Solvents for Electrochemistry. Z. Phys. Chem. 218, 255-283 (2004).

[8] J. Halbritter, G. Repphun, S. Vinzelberg, G. Staikov \& W. Lorenz. Tunneling mechanisms in electrochemical STM - distance and voltage tunneling spectroscopy. Electrochim. Acta 40, 1385 - 1394 (1995).

[9] M. Hugelmann \& W. Schindler. Tunnel barrier height oscillations at the solid/liquid interface. Surf. Sci. 541, L643-L648 (2003).

[10] I. A. Shkrob. Ammoniated Electron as a Solvent Stabilized Multimer Radical Anion. J. Phys. Chem. A 110, 3967-3976 (2006).

[11] X. Li, J. He, J. Hihath, B. Xu, S. M. Lindsay \& N. Tao. Conductance of Single Alkanedithiols: Conduction Mechanism and Effect of MoleculeElectrode Contacts. J. Am. Chem. Soc. 128, 2135-2141 (2006).

[12] N. Néel, J. Kröger, L. Limot, T. Frederiksen, M. Brandbyge \& R. Berndt. Controlled Contact to a $\mathrm{C}_{60}$ Molecule. Phys. Rev. Lett. 98, 065502 (2007).

[13] H. B. Akkerman \& B. de Boer. Electrical conduction through single molecules and self-assembled monolayers. J. Phys.: Condens. Matter 20, 013001 (2008).

[14] B. Koslowski, A. Tschetschetkin, N. Maurer \& P. Ziemann. 4Mercaptopyridine on $\mathrm{Au}(111)$ : a scanning tunneling microscopy and spectroscopy study. Phys. Chem. Chem. Phys. 13, 4045-4050 (2011). 
[15] J. G. Simmons. Generalized Formula for the Electric Tunnel Effect between Similar Electrodes Separated by a Thin Insulating Film. $J$. Appl. Phys. 34, 1793-1803 (1963).

[16] G. Wang, T.-W. Kim, H. Lee \& T. Lee. Influence of metal-molecule contacts on decay coefficients and specific contact resistances in molecular junctions. Phys. Rev. B 76, 205320 (2007).

[17] J. Zhou \& B. Xu. Determining contact potential barrier effects on electronic transport in single molecular junctions. Appl. Phys. Lett. 99, 0421041 - 0421043 (2011).

[18] J. Zhou, C. Guo \& B. Xu. Electron transport properties of single molecular junctions under mechanical modulations. J. Phys.: Condens. Matter 24, 164209 (2012).

[19] H. B. Akkerman, R. C. G. Naber, B. Jongbloed, P. A. van Hal, P. W. M. Blom, D. M. de Leeuw \& B. de Boer. Electron tunneling through alkanedithiol self-assembled monolayers in large-area molecular junctions. Proc. Natl. Acad. Sci. U.S.A. 104, 11161-11166 (2007).

[20] R. L. McCreery. The merger of electrochemistry and molecular electronics. Chem. Rec. 12, 149-163 (2012).

[21] J. Coombs, M. Welland \& J. Pethica. Experimental barrier heights and the image potential in scanning tunneling microscopy. Surf. Sci. 198, L353-L358 (1988).

[22] D. R. Lide (ed.) CRC Handbook of Chemistry and Physics (CRC Press, 2005), 86 edn.

[23] K. Sebastian \& G. Doyen. Electrochemical scanning tunneling microscopy: does the orientational polarization of the liquid play any role? Surf. Sci. 290, L703 - L710 (1993).

[24] B. Xu \& N. J. Tao. Measurement of Single-Molecule Resistance by Repeated Formation of Molecular Junctions. Science 301, 1221-1223 (2003). 


\section{Summary}

Ever since its inception in the early 1980s, the Scanning Tunnelling Microscope (STM) has provided surface scientists with a powerful tool for the characterisation of all manner of conductive samples. By harnessing the possibilities of quantum mechanical tunnelling, the STM is capable of imaging and manipulating features down to the single atom scale. In addition to these qualitative tools, the STM also allows for the (semi-)quantitative analysis of samples through the use of Scanning Tunnelling Spectroscopy (STS). A large variety of different types of STS measurements exists, which can be roughly divided into three categories: open-loop, closed-loop and lock-in STS. Through the use of STS, such parameters as the work function, local density of states (LDOS) and band gap of a sample can be probed. While using the STM technique for qualitative measurements does not require a thorough understanding of the underlying theory, obtaining accurate quantitative results is often far more involved. Even when considering all conventional theoretical contributions to the tunnelling current, spectroscopy experiments occasionally yield unexpected results. As such, the main goal of this thesis is the study of several different spectroscopic configurations and tools in order to further elucidate the underlying mechanisms of the tunnelling process and the common pitfalls of spectroscopy experiments.

Probing the behaviour of quantum mechanical tunnelling junctions requires the use of sophisticated hardware setups. The experimental hardware used to obtain the data presented in this thesis is presented in Chapter 2. Additionally, a brief introduction to electrochemistry and electrochemical STM is given.

The local density of states (LDOS) provides information about the electronic and chemical configuration of a probed sample and is conventionally extracted from a current-voltage or $\mathrm{I}(\mathrm{V})$ spectroscopy trace. Measuring an $\mathrm{I}(\mathrm{V})$ trace requires the STM operator to disable to electronic feedback loop via a sample-and-hold system, which is not a standard function for all STM systems. Chapter 3 presents an alternative method of obtaining the LDOS of a sample through the use of distance-voltage or $z(V)$ spectroscopy. This 
method does not require the feedback loop to be disabled, making it widely accessible. Obtaining the LDOS from a measured spectroscopy trace can be done via a number of different normalisation methods. The numerical analysis performed in Chapter 3 exposes a number of shortcomings inherent to the widely used method of determining the LDOS from the differential conductivity, i.e. the derivative of the tunnelling current with respect to the applied bias voltage divided by the tunnelling conductance. Finally, several alternative numerical schemes to determine the LDOS from $\mathrm{I}(\mathrm{V})$ and $\mathrm{z}(\mathrm{V})$ spectroscopy traces are presented and compared in order to show the effect of different numerical approximations on the final obtained results.

Chapter 4 deals with the remarkable results obtained while performing Transition Voltage Spectroscopy (TVS) measurements in metal-vacuum-metal junctions. Originally envisioned as a method of determining the tunnelling barrier height in molecular transport at relatively low bias voltages, TVS was also expected to provide a means of discriminating between molecular junctions and vacuum junctions. Molecular break junction (MBJ) experiments carried out by Trouwborst et al. to validate this claim led to unexpected results, as it was found that the distance dependence of the transition voltage in vacuum junctions was weaker than in molecular junctions; completely opposite of theoretical predictions. Taking the existence of image charges into account was insufficient to completely dispel this discrepancy. In Chapter 4, the MBJ experiments performed by Trouwborst et al. are repeated using an STM system. Despite the fact that the geometry of the STM junction should lead to a stronger image charge effect, the measured results were found to defy theoretical predictions nonetheless, with the transition voltage decreasing as a function of inverse gap width.

Partially inspired by the puzzling results mentioned in Chapter 4, Chapter 5 contains an in-depth look at the Simmons model and the impact of the different individual contributions to the total tunnelling barrier. Decoupling these terms is done by numerically fitting obtained spectroscopy traces to the detailed Simmons model with varying degrees of freedom for certain expressions. From this numerical fitting method, the work function of the sample and the influence of image charges can be determined. While the tunnelling barrier is conventionally determined through the use of $\mathrm{I}(\mathrm{z})$ spectroscopy, $z(V)$ spectroscopy also yields all the necessary data needed in order to evaluate the Simmons tunnelling formula. As such, Chapter 5 also contains an explicit comparison between these two methods in order to determine the 
viability of using $z(V)$ measurements to extract the local tunnelling barrier. Analysis of obtained $\mathrm{I}(\mathrm{z})$ and $\mathrm{z}(\mathrm{V})$ traces reveals that both methods are interchangeable when determining the local tunnelling barrier.

The presence of molecules within the tunnelling junction can have a profound effect on the extracted barrier values. In Chapter $6, \mathrm{I}(\mathrm{z})$ measurements were performed under ambient conditions, as well as in a variety of different solvents. From the exponential dependence of the measured current on the tip-sample distance, it was concluded that tunnelling remains the primary means of charge transfer for all measured junctions. However, a deviation from this exponential decay was observed around the starting point of all $\mathrm{I}(\mathrm{z})$ curves, possibly indicating an alternate charge transfer mechanism. An overview of the extracted barrier heights shows a proportional dependence between the length of the used molecules and the height of the tunnel barrier. 



\section{Samenvatting}

Sinds zijn invoering in de vroege jaren 80 is de Scanning Tunnelling Microscope (STM) door oppervlaktewetenschappers gebruikt als een krachtig hulpmiddel voor het karakteriseren van een grote verscheidenheid aan geleidende oppervlakken. Door gebruik te maken van kwantummechanische tunneling is de STM in staat tot het afbeelden en manipuleren van oppervlakken op atomaire schaal. Naast deze kwalitatieve mogelijkheden stelt de STM de gebruiker ook in staat tot het doen van (semi-)kwantitatieve analyse van oppervlakken door het gebruik van Scanning Tunnelling Spectroscopy (STS). Er bestaat een groot aantal verschillende types STS-metingen, die grofweg in drie categorieën kunnen worden onderverdeeld: open-loop, closed-loop en lock-in STS. Met behulp van STS-metingen kunnen parameters zoals de werkfunctie, lokale toestandsdichtheid (local density of states, ook wel LDOS) en bandgap van een materiaal bepaald worden. Hoewel een grondig begrip van de achterliggende theorie geen vereiste is voor het verkrijgen van kwalitatieve informatie met behulp van de STM, is dit voor kwantitatieve analyse een ander verhaal. Zelfs wanneer alle conventionele theoretische bijdragen aan de tunnelingstroom in acht worden genomen zijn onverwachte resultaten niet ongewoon. Om deze reden is het hoofddoel van deze dissertatie het bestuderen van verschillende spectroscopieconfiguraties en -hulpmiddelen om de onderliggende mechanismen van het tunnelingproces beter te belichten en inzicht te bieden in de voornaamste valkuilen van spectroscopie-experimenten.

Het bestuderen van het gedrag van kwantummechanische tunneljuncties vereist het gebruik van ingewikkelde opstellingen. De opstellingen die zijn gebruikt bij het verkrijgen van de data die in dit proefschrift worden gepresenteerd zijn beschreven in Hoofdstuk 2. Hiernaast wordt een korte introductie over elektrochemie en elektrochemische STM gegeven.

De lokale toestandsdichtheid (local density of states, of LDOS) geeft informatie over de elektronische en chemische eigenschappen van het onderzochte materiaal en wordt doorgaans bemachtigd door middel van stroom-voltage ofwel $\mathrm{I}(\mathrm{V})$ spectroscopie. Om een $\mathrm{I}(\mathrm{V})$ karakteristiek te bemachtigen is het nodig dat de elektronische terugkoppellus van de STM wordt uitgeschakeld 
met behulp van een sample-and-hold systeem, een functie die niet standaard inbegrepen is bij ieder STM-systeem. Hoofdstuk 3 beschrijft een alternatieve methode voor het meten van de LDOS door middel van afstand-voltage ofwel $\mathrm{z}(\mathrm{V})$ spectroscopie. Het uitschakelen van de terugkoppellus is geen vereiste voor het gebruik van deze techniek, hetgeen de techniek breed toegankelijk maakt. Om de LDOS te onttrekken van een gemeten spectroscopiekarakteristiek kan een aantal normalisatiemethoden gebruikt worden. De numerieke analyse die in Hoofdstuk 3 wordt gebruikt toont enkele tekortkomingen die inherent zijn aan de meest gebruikelijke methode om de LDOS te bepalen; namelijk het bepalen van de differentiële geleidbaarheid door de afgeleide van de tunnelstroom naar de aangelegde biaspotentiaal te delen door het geleidend vermogen van de tunnelbarrière. Uiteindelijk worden enkele alternatieve numerieke methoden voor het bepalen van de LDOS op basis van $\mathrm{I}(\mathrm{V})$ en $z(V)$ spectroscopie aangedragen en vergeleken om het effect van numerieke benaderingen op de uiteindelijke uitkomst van deze methoden te bepalen.

Hoofdstuk 4 gaat over de opmerkelijke resultaten die zijn verkregen gedurende overgangsvoltagespectroscopie (Transition Voltage Spectroscopy, ook wel TVS) metingen in metaal-vacuüm-metaaljuncties. Hoewel TVS in eerste instantie gezien werd als een manier om de hoogte van de tunnelbarrière in moleculair transport te bepalen bij relatief lage biasvoltages, verwacht men ook dat TVS gebruikt kan worden om onderscheid te maken tussen moleculaire juncties en vacuümjuncties. Moleculaire breekjunctie-experimenten (MBJ) uitgevoerd door Trouwborst et al. om deze bewering te testen leidden tot onverwachte resultaten: de afstandsafhankelijkheid van het overgangsvoltage in vacuümjuncties was zwakker dan die in moleculaire juncties, compleet tegengesteld aan theoretische voorspellingen. Het in acht nemen van het bestaan van beeldladingen was niet afdoende om deze discrepantie volledig weg te nemen. In Hoofdstuk 4 worden de metingen die door Trouwborst et al. uitgevoerd zijn herhaald met behulp van een STM-systeem. Ondanks het feit dat de geometrie van de STM-junctie ervoor zorgt dat de bijdrage van beeldladingen toeneemt staan de gemeten resultaten nog steeds loodrecht tegenover de theoretische voorspellingen: het overgangsvoltage neemt af als functie van inverse junctiebreedte.

Hoofdstuk 5 bevat, deels geïnspireerd door de onverwachte resultaten uit Hoofdstuk 4, een uitgebreide kijk op het Simmons model en de invloed van de verschillende bijdragen aan de tunnelbarrière. Door middel van het numeriek fitten van gemeten spectroscopiekarakteristieken aan het gedetailleerde 
Simmons model met variërende vrijheidsgraden voor bepaalde uitdrukkingen worden deze afzonderlijke termen ontkoppeld. Door gebruik te maken van deze numerieke fitmethode kunnen de werkfunctie van het materiaal en de invloed van beeldladingen bepaald worden. Hoewel de tunnelbarrière normaliter bepaald wordt door gebruik van $\mathrm{I}(\mathrm{z})$ spectroscopie, bevatten $\mathrm{z}(\mathrm{V})$ spectroscopiekarakteristieken ook alle informatie die benodigd is om de Simmons tunnelformule uit te werken. Om deze reden bevat Hoofdstuk 5 ook een expliciete vergelijking tussen deze twee methoden om zodoende de gangbaarheid van het gebruik van $\mathrm{z}(\mathrm{V})$ metingen voor het bepalen van de lokale tunnelbarrière vast te stellen. Analyse van gemeten $\mathrm{I}(\mathrm{z})$ en $\mathrm{z}(\mathrm{V})$ karakteristieken laat zien dat beide methoden uitwisselbaar zijn voor het bepalen van de lokale tunnelbarrière.

De aanwezigheid van moleculen in de tunneljunctie kan een uitgesproken effect hebben op de gemeten barrièrehoogtes van deze junctie. In Hoofdstuk 6 worden $\mathrm{I}(\mathrm{z})$ metingen in zowel omgevingsomstandigheden als een variëteit aan oplosmiddelen gepresenteerd. Op basis van de exponentiële afhankelijkheid van de gemeten stroom als functie van de afstand tussen de tip en het oppervlak kan geconcludeerd worden dat tunneling het primaire ladingsoverdrachtsmechanisme is in alle gemeten omstandigheden. Echter is een afwijking van dit gedrag zichtbaar rond het startpunt van alle gemeten I(z) karakteristieken, hetgeen mogelijk duidt op een alternatief ladingstransportmechanisme. Een overzicht van de gemeten barrièrehoogtes laat een proportioneel verband tussen de lengte van de gemeten moleculen en de hoogte van de barrière zien. 



\section{List of publications}

- C. Hellenthal, K. Sotthewes, M.H. Siekman, E.S. Kooij and H.J.W. Zandvliet, Closed-loop conductance scanning tunneling spectroscopy: demonstrating the equivalence to the open-loop alternative, accepted for publication in Beilstein Journal of Nanotechnology (2015).

- K. Sotthewes, C. Hellenthal, A. Kumar and H.J.W. Zandvliet, Transition voltage spectroscopy of scanning tunneling microscopy vacuum junctions, RSC Advances, 4, 61, 32438-32442 (2014).

- C. Hellenthal, R. Heimbuch, K. Sotthewes, E.S. Kooij and H.J.W. Zandvliet, Determining the local density of states in the constant current STM mode, Physical Review B - Condensed Matter and Materials Physics, 88, 3, 035425 (2013).

- A. Kumar, S.K.C. Palanisamy, J.M. Boter, C. Hellenthal, J.E. ten Elshof and H.J.W. Zandvliet, Imaging of $\mathrm{Ti}_{0.87} \mathrm{O}_{2}$ nanosheets using scanning tunneling spectroscopy, Applied Surface Science, 265, 201-204 (2013).

- E.S. Kooij, W. Ahmed, C. Hellenthal, H.J.W. Zandvliet and B. Poelsema, From nanorods to nanostars: Tuning the optical properties of gold nanoparticles, Colloids and Surfaces A: Physicochemical and Engineering Aspects, 413, 231-238 (2012).

- C. Hellenthal, W. Ahmed, E.S. Kooij, A. van Silfhout, B. Poelsema and H.J.W. Zandvliet, Tuning the dipole-directed assembly of core-shell nickel-coated gold nanorods, Journal of Nanoparticle Research, 14, 9, 1107 (2012).

- W. Ahmed, R.P.B. Laarman, C. Hellenthal, E.S. Kooij, A. van Silfhout and B. Poelsema, Dipole directed ring assembly of Ni-coated Aunanorods, Chemical Communications, 46, 36, 6711-6713 (2010). 



\section{Naschrift en dankwoord}

En dan nu het best gelezen en best begrepen onderdeel van menig proefschrift. Een ieder die dit deel van mijn thesis als eerste heeft opgezocht wil ik toch aanraden om de rest ook nog even vluchtig door te bladeren; het beschreven werk is bij vlagen nog best interessant en er staan hier en daar zelfs een paar leuke plaatjes in.

Om eerlijk te zijn had ik na in mijn afstuderen bij de kersverse Physics of Interfaces and Nanomaterials groep in oktober 2010 geen flauw idee wat de volgende stap moest worden. De mix van experimentele en computationele nanotechnologie/fysica was mij echter goed bevallen en zo besloot ik, mede geïnspireerd door twee (ex-)collegastudenten, om nog vier jaar betaald door te studeren. Helaas waren er geen middelen voorhanden om mijn werk met gouden nanodeeltjes voort te zetten, maar er waren recent nog wel drie andere voorstellen gehonoreerd. Zo geschiedde het dat ik de keuze kreeg uit drie verschillende projecten: de elektronische eigenschappen van 1-D systemen, nanobellen en het NEEDL-Chem project. Uiteindelijk viel de keuze op het NEEDL-Chem project, mede dankzij de veelzijdigheid van het onderwerp, de potentiële toepassingen en het relatief onontgonnen vakgebied. Het overzetten van een traditionele vacuümtechniek als STM naar een natte elektrochemische omgeving om zodoende elektronen te 'vangen' tussen vloeistofmoleculen sprak tot de verbeelding en beloofde een significante theoretische en experimentele uitdaging. Daarnaast zag ik potentie voor het combineren van experimenteel onderzoek met numerieke simulatie en analyse om zodoende het onderwerp mezelf eigen te maken, zoals ook het geval was tijdens mijn afstudeerproject.

De meeste mensen die dit boekje zullen lezen weten al dat het helaas nooit zover heeft mogen komen. Het feit dat de opstelling minder kant-en-klaar was dan verwacht, gecombineerd met de gebrekkige en deels achterhaalde documentatie zorgde ervoor dat het wiel niet alleen vervangen maar ook opnieuw uitgevonden moest worden. Het feit dat iedere oplossing weer nieuwe problemen introduceerde of blootlegde heeft er voor gezorgd dat het project nooit echt van de grond is gekomen. Het overgrote deel van het (repara- 
tie)werk wat ik gedurende de afgelopen vier jaar heb uitgevoerd was helaas dan ook niet geschikt om op te nemen in deze thesis. Desalniettemin is dit boekje er uiteindelijk toch gekomen, hetgeen nooit mogelijk was geweest zonder de ondersteuning van een groot aantal mensen die ik op de komende paar bladzijden graag wil bedanken.

Ten eerste wil ik graag degene bedanken die het in eerste instantie mogelijk heeft gemaakt voor mij om mijn promotietraject te beginnen. Harold, ook jij zal dit project in eerste instantie anders in gedachten gehad hebben, maar ondanks alle opeenvolgende tegenslagen ben je altijd blijven zoeken naar manieren om content te genereren voor deze thesis, waarbij je de technische tekortkomingen van de oude opstelling als inspiratie gebruikte voor de theorieën die ten grondslag liggen aan Hoofdstuk 3 en 5. Hoewel onze verwachtingspatronen over het algemeen vrij ver uitelkaar lagen is het mede dankzij jouw onuitputbare optimisme dat deze thesis tot stand is gekomen.

Stefan, bedankt voor de dagelijkse begeleiding door de jaren heen. Ondanks het feit dat STM eigenlijk niet jouw expertisegebied is was je toch altijd bereid om mee te denken en mee te rekenen aan de meest recente theorie die op dat moment getest diende te worden. Ook het proeflezen van mijn artikelen, posters en uiteindelijk ook deze thesis wordt op prijs gesteld. De knullige foutjes waar je tijdens het schrijven van een tekst op een gegeven moment blind voor wordt wist jij er dankzij je oog voor details altijd feilloos uit te pikken.

De overige leden van mijn promotiecommissie wil ik ook graag bedanken voor het plaatsnemen in mijn commissie en de investering van tijd en moeite die hiermee gepaard gaat.

Arie, bedankt voor het introduceren van de ECSTM en de ondersteuning gedurende het begin van mijn promotietraject.

Zoals reeds vermeld is er erg veel tijd gestoken in het repareren en (her)ontwikkelen van de ECSTM en toebehoren. Zonder de ondersteuning van de technische staf was dit nooit gelukt, en daarom wil ik ook deze mensen graag bedanken voor hun bijdrage aan het project.

Herman, tot aan je pensioen heb je actief meegedacht en input geleverd voor het project. Ongeacht of we de oude opstelling moesten repareren, verbeteren of domweg doorgronden, je was altijd bereid om je expertise en systematische aanpak ter beschikking te stellen. Mede dankzij jou is de huidige opstelling beter dan hij ooit geweest is.

Hans, voor het bestellen van materiaal en de meer 'hands-on' klussen kon 
ik altijd bij jou terecht, waarvoor dank.

Martin, zonder jouw hulp zou er nu nog steeds geen fatsoenlijk werkende ECSTM zijn. Hoewel je pas gedurende het laatste jaar van mijn $\mathrm{PhD}$ bij de groep bent gekomen heb je duidelijk je stempel op het project gedrukt. Wat jij binnen een paar weken met een oscilloscoop en een soldeerbout voor elkaar hebt gekregen is niets minder dan indrukwekkend.

Met betrekking tot technische ondersteuning wil ik ook Geert Mentink van TCO bedanken voor de reparaties en aanpassingen die hij aan de oude ECSTM controller hardware heeft uitgevoerd. Uiteindelijk wil ik Simone bedanken voor de ondersteuning op administratief gebied.

Gedurende mijn tijd bij PIN (en SSP) heb ik een groot aantal collega's zien komen en gaan. Ik ga me niet wagen aan het opstellen van een volledige lijst met namen, dus bij deze wil ik iedereen bedanken voor de tijd die ik heb doorgebracht bij Solid State Physics en Physics of Interfaces and Nanomaterials. Ik wil me echter in het bijzonder richten tot een subgroep van collega's, te beginnen met mijn mededeelnemers aan de onvergetelijke "Best Roadtrip Ever".

Kai, een paar jaar geleden had ik nooit geloofd dat ik het zo goed zou kunnen vinden met iemand die zo uitgesproken aanwezig kan zijn als jij. Toen duidelijk werd dat de ECSTM toch echt geen content op ging leveren binnen mijn promotietraject werd er besloten om uit te wijken naar de 'reguliere' STMs in het Nanolab, waaronder de RHK waar jij op dat moment de scepter over zwaaide. Naast de vele metingen die je voor me hebt gedaan was je ook altijd bereid om mee te denken over de interpretatie van diezelfde metingen, en je gedrevenheid om precies te doorgronden wat er nou precies aan de hand was heeft tot veel nuttige inzichten geleid. De realisatie van Hoofdstuk 3, 5 en met name 4 was niet mogelijk geweest zonder jou.

Patrick, als 'bijna buurman' kon ik zowel op het werk als daarbuiten bij je aankloppen voor een extra paar handen of een goed gesprek. De dagelijkse gesprekken over van alles en nog wat bij jou op het kantoor maakten de lange dagen van nietsdoen aan het begin van mijn promotietraject een stuk dragelijker en ook jij was altijd bereid om mee te denken over de meest recente theorieën en problemen. Ook de samenwerking tijdens de laatste jaren van onze studie en het afstuderen in 'de Punt' zullen me nog lang bijblijven.

René (met accent!), jouw bereidheid tot (en genoegen in?) het regelen, onderhandelen en uitzoeken van allerlei logistieke details heeft ervoor gezorgd dat de roadtrip onverwachts soepel en goedkoop is verlopen. Op het werk kon 
ik naast STM-gerelateerde vragen en discussies ook altijd bij je terecht om van gedachten te wisselen over de belangrijkere zaken in het leven, zoals $\mathrm{Pi}$ projecten, de meest recente uitgave van Time Magazine en genetische defecten bij grote katachtigen. Hoewel de resultaten uiteindelijk niet in Hoofdstuk 3 terecht zijn gekomen wil ik je toch bedanken voor de moeite die je hebt gedaan in de zoektocht naar de ongrijpbare Ge(110) LDOS-piek.

Robin, bedankt voor je hulp met de optische microscoop en de zuurstofmeter. Ook jou wil ik bedanken voor de (wetenschappelijke) discussies tijdens mijn promotietraject en de prettige samenwerking tijdens de studie, met name de tijd die we in Genève hebben doorgebracht.

In de categorie 'collega's' wil ik als laatste nog drie personen bedanken voor hun hulp gedurende mijn promotietraject.

Erik, bedankt voor de ondersteuning met betrekking tot de optische microscoop, ook nadat ik de coating van je microscoopobjectief had weggeëtst.

Pantelis, bedankt voor de AFM-metingen op $\mathrm{Cu}(100)$ waaruit bleek dat preferentieel etsen aan slijpgroeven een significant effect had op de kwaliteit van het sample.

En Hairong, bedankt dat je op korte termijn nog voor drie $\mathrm{Au}(111)$ samples kon zorgen waardoor ik genoeg tijd had om de metingen voor Hoofdstuk 6 af te ronden en toch nog een beetje ECSTM in deze thesis te verwerken.

Joachim, aan een geslaagde promotie gaat een geslaagde studie vooraf, en daarom wil ik jou bij dezen ook graag bedanken voor de vele uren op Vloer 4/5 van de Hogekamp, de stage in Genève en het afstuderen in 'de Punt'. Ook de periodieke afspraken van de afgelopen paar jaar om bij te praten waren altijd erg geslaagd.

Gelukkig is er ook nog een wereld buiten de werkvloer en ook in deze wereld zijn er mensen die ik wil bedanken voor hun indirecte bijdrage aan deze thesis. De opmaak van 'de playgroup' is door de jaren heen nogal veranderd, dus ook hier ga ik mezelf ervan weerhouden een poging te wagen om een volledige lijst met namen op te stellen. Beste mensen, ontzettend bedankt voor de vele jaren ontspanning en vermaak die ik met jullie heb meegemaakt. Of het nou kaart-, bord-, computer- of gezelschapspellen waren, menig avond en weekeind is voorbij gevlogen tijdens het managen van treinen en sporen, het leiden van (intergalactische) beschavingen, het handelen in allerlei goederen en het neerschieten van zombies. Ook de gesprekken over de serieuze en minder serieuze dingen des levens die we tijdens of tussen deze activiteiten door hebben gevoerd worden zeer op prijs gesteld. 
In het bijzonder wil ik graag mijn beide paranimfen bedanken, niet alleen voor de ondersteuning tijdens mijn verdediging, maar ook voor de vele jaren vriendschap die hieraan vooraf zijn gegaan.

Stefan, op het moment dat ik dit schrijf is het alweer bijna tien jaar geleden dat we gelijktijdig aan onze studies aan de UT begonnen en onze intrek namen aan de Losplaats. Het initiatief om samen met een paar klasgenoten een huis in de omgeving van Enschede te zoeken kwam destijds van jouw kant, evenals een groot deel van de uitvoering van dit plan. Door de jaren heen heb ik nog vaker mogen profiteren van je pragmatische en nuchtere instelling, of dit nou in de omgang met slonzige huisgenoten was of met problemen gerelateerd aan de studie. De afgelopen paar jaar zijn voor ons allebei vrij bewogen geweest, maar ik kon altijd langskomen voor een goed gesprek of de nodige ontspanning in de vorm van een bord- of kaartspel. Ik hoop van harte dat dit de komende jaren niet zal veranderen.

Erik, een oud Nederlands cliché leert ons dat een goede buur beter is dan een verre vriend. Ondanks het feit dat ik weinig ervaring heb met goede buren, durf ik toch te stellen dat jij een uitzondering op deze regel bent. Ik kan mijn waardering voor onze vriendschap gedurende onze tijd op de middelbare school niet sterk genoeg benadrukken. En hoewel we elkaar tegenwoordig nog maar sporadisch spreken doet het me altijd goed om vast te kunnen stellen dat er eigenlijk maar weinig tussen ons is veranderd sinds die tijd. Overigens heb ik me laten vertellen dat een promotie gelijk staat aan 'trouwen met de universiteit', hetgeen een paranimf dus gelijk maakt aan een 'best man'. Ik weet niet of we hiermee wat jou betreft quitte staan, maar je zal het er in ieder geval voorlopig mee moeten doen.

Als laatste wil ik uiteraard ook mijn familie bedanken. Zonder jullie onvoorwaardelijke steun, advies en liefde door de jaren heen was dit alles niet mogelijk geweest.

Chris Hellenthal Enschede, april 2015 


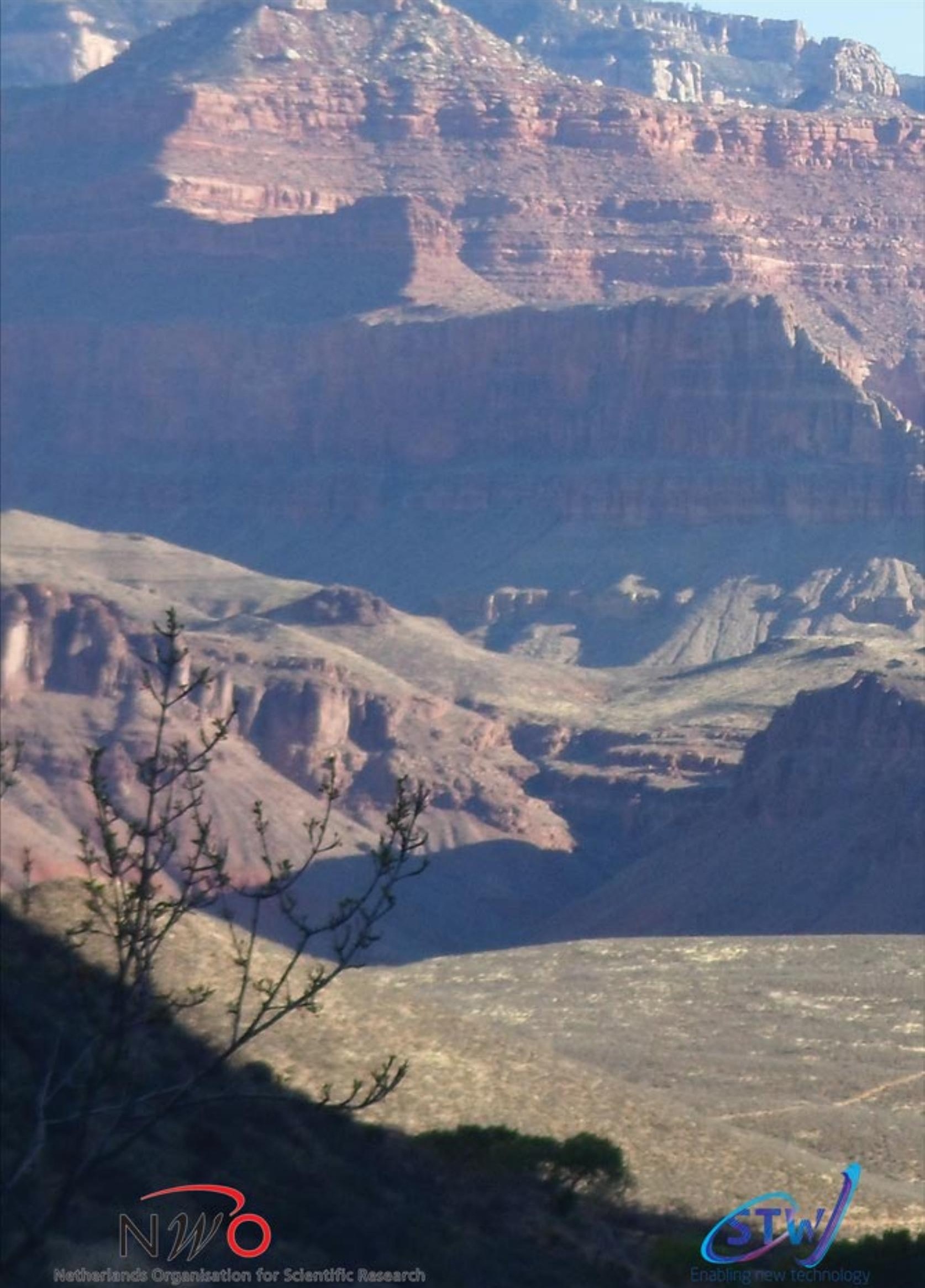